\title{
Generations of Transitional Justice in the World
}

\author{
Bishnu Pathak \\ A Nobel Peace prize nominee \\ Professor, Senior Commissioner \\ Commission of Investigation on Enforced Disappeared Persons (CIEDP), Nepal
}

\begin{abstract}
The objectives of the paper are to investigate the axiomatic truth and record the human wrongdoings of the past, deliver justice to the victims at present, make perpetrators accountable and initiate generous change in the rule of law for prosperous, peaceful and harmonious nation. The state-of-the-art paper is prepared based upon literature review, exchanging and sharing, and a practical observation approach rather than theoretical-analytical conception, except Generation. An interdisciplinary (politicolegal) word, 'Transitional Justice' (TJ) is healing the violations and/or abuses of yesterday, investigating and reconciling today and hoping to protect the tomorrow for not only a few privileged, but for the people of all Generations. The Generation tends to ascertain cause, nature, degree and patterns of identity-based crimes and genocide, determine the role of perpetrators and analyze the impact of the Truth Commission. Generally, Generation refers to the biological age groupings ( 20 to 30 years) that live together and share similar characteristics - attitudes, behaviors, contexts, sufferings and cultures. The paper reviews over 90 TJ countries in Five Generations (I, II, III, IV and 0), starting from the post-World War II to the present day world. Generation-I presents a genesis of $\mathrm{TJ}$, a notion changed from the holocaust to the retributive justice which comprises the analyses of Nuremberg Trial and Tokyo Tribunal. Rather than making the main perpetrators involved in World War (WW) II accountable, the Nuremberg Trial has been a holier-than-thou betrayal to the Germans by a pseudo trial, and immunity to 'French, Soviet Union, Americans, British and Japanese Emperor' and Geneva Convention violators owing to a high political masquerading and retribution. Generation-II reveals a notion changed from internecine war crimes to humanitarian justice. It compares and contrasts the functions of the Truth Commissions that have a direct structural link with perpetrators' four Ds (viz. delay, deceive, deny and dilute) approaches of TJ. Beyond domestication, TJ is an international human rights law, international criminal law and international humanitarian law. TJ has been more political in nature and less legal in practice. Generation-III tends to a notion changed from domestic criminal jurisprudence to international tribunal justice. The western developed and non-signatory nations of the Rome Statute try hard to establish and control the International Criminal Court (ICC) to their bad relation with post-conflict countries. Generation-IV discloses a notion changed from sectarian violence to reconcile justice. In such cases, non-state elite actors normally engage against the weak and poor people to prove their superiority conducting communal apartheid and cultural genocide. Lastly, Generation-0 (Zero) refers to a notion changed for justice establishing the Truth Commission. Truth Commissions have been unable to identify and investigate the human rights violations and/or abuses in the post-conflict periods, despite huge national and international pressures. Generally, what for transitional justice: victor (perpetrator) or loser (victim and or survivor)? The answer is: 'world's Transitional Justice ironically ensures freedom to the perpetrators further limiting justice to the poor and weak victims and society at large' in all Generations. On the other, the universe moves towards the identity-based multi-polar new world order setting owing to innumerable interests and practices of the Transitional Justice system.
\end{abstract}

Keywords: generation, truth commission, transitional justice, international criminal court, truth, justice, reparation, non-recurrence, victim, perpetrator, and human rights violations or abuses. 


\section{INTRODUCTION}

Transitional Justice (TJ) is a politico-legal word. It collects (truth) statement or storytelling from the complainant of the loved-one loss; (victim) realizes justice by achieving something in return of something damaged or someone lost; (perpetrator) promises for not doing it again bringing them (of war crimes and crimes against humanity) into accountability; and (the state) becomes responsible (enforcing rule of law) to maintain legal governance. Storytelling is a long-established cultural tradition where people tell stories to transfer knowledge between generations (Lugmayr et al., December 11, 2017). In this context, storytelling is an emotional narrative of complainant (often victim or survivor family), for instance, who/when/how/why was disappeared, who was responsible for such enforced disappearance and by whose direction. TJ is not an isolated, but collective social approach, beyond law and politics.

Transitional Justice often reconciles (victim-perpetrator) in the society pursuing judicial and non-judicial procedures (Bandi, 2013). In general, TJ never hurts, but heals the victims (Teitel, 2000). TJ shows respect to the victims, including even those who do not deserve it. But, TJ has a direct structural-link with perpetrators' four Ds (viz. delay, deceive, deny and dilute) approaches owing to the influence of perpetrators through state-and-power mechanism. On the other hand, the victims are those who are economically poor, socio-culturally marginalized, politically excluded, legally un-accessed and administratively disadvantaged.

The notion of Generation has been explicitly defined as all of the people born and living together almost at the same time. It is spoken in everyday lives of people. Generation has certain time-frame too, based on which people belonging to a certain time period often face similar ideas or attitudes, behaviors, contexts, problems, politics and cultures. People often share and gain similar characteristics. It is not just a biological age groupings (20 to 30 years) and family relationships within the community or society, but also the trends and patterns of truth, justice and reparation systems beyond the period. Generally, Generation exists in politico-legal, socio-historical and economic contexts which initiate the process of social change and social order and it changes over social generations.

Generation is sometimes a threat to stability as well as the opportunity for social transformation (Ryder, 1965) and transformative justice. The past has been a witness that generational conflict exits between two age cohorts: older and younger people because of their experiencing, learning and needing-desire. It happens because of various speaking being exercised by older and younger people owing to social historical references, culturally determined experiences and individual interpretations (Grenier, 2007). Generation includes "the nature of time, relationship between biology and social, psycho-social connections of language and knowledge" (Pilcher, September 1994). It points to 'definite modes of behavior, feeling and thought' (Mannheim, 1952). Generation is a group of smart, ambitious and questioning fast-thinkers in multi-tasks (Stuart, July 2015). And literature review suggests that young people's relationship with technology shall be more complicated (Stuart, July 2015) because of deliverance to change. Change is inevitable to class, gender, caste/ethnicity, race, culture, education, among others due to prevalence of rights, duties and needs, based on people's high changing expectations (of technology).

The aim of this paper is to categorize the Transitional Justice Generation investigating the axiomatic truth of human wrongdoings occurred within, between and or among the State to State, State to non-State and non-State to non-State in 8-decade (1939-2019) periods in the post-conflict situations. The aim refers to a set of the judicial and non-judicial measures of all cases of systematic human rights violations and/or abuses and International Humanitarian Law (IHL); to provide justice to the victims for their dignified lives; to prosecute and punish to 
the perpetrators being accepted accountability against their past crimes and to prevent such violations or abuses from being repeated again; and to adopt non-recurrence accessing for an effective remedy to initiate various kinds of institutional reforms in the State mechanism.

The General Objective of this transitional justice study is to investigate the cases of wrongdoings: war crimes, crimes against humanity and genocide and explore the initiatives and practices that are adopted in the course of truth seeking. It sets up jurisdiction over the offense committed, bringing the responsible perpetrators under the accountability prosecuting them; restores justice to the victims, survivors, their families and society to some extent, pays respect and satisfies them. It tries to repair or heal the damages in the families, communities and societies either serving relief or reparation; accepts reconciliation among desired actors, and reforms institution eliminating the chances to recur such conflicts in future.

The Specific Objective is to examine and evaluate a complete cause, nature, degree and patterns of Generation based on the origin, use and development of the TJ system. The Transitional Justice Generation compares within, between and among the past armed struggles that had happened during colonial, slavery, anarchical and cultural and identity-based armed conflicting periods.

The author uses the word "Generation" that widely prevails in the present day world. The TJ Generation is prepared on the basis of author's three decade long learning and experiences of working with human wrongdoings, human insecurities and crimes, and crimes against humanity, analysis of their cause (of conflict) and effect (of truth commission) relationships. Moreover, the author's reflections are gained either through literature review or exchanging and sharing and participant observation approach rather than theoretical conception. Therefore, this state-of-the-art paper is pursued based on the lessons-learned centric conception and the practical underpinning of truth seeking for justice to victims, survivors and society at large. The pioneer study of Generation briefly adopts victims-centric and readers' friendly approaches to read a whole world's transitional justice processes in a single paper.

The study reviews and collects information starting from (duties and responsibilities and rights of) the Nuremberg Trials establishment to other Transitional Justice bodies formed till mid-2019. The study is further categorized into five divisions, a unique type of Generation development process. Such categorization is based on justice for the victims and their families for dignified lives. The Generation-I defines the Nuremberg Trials and Tokyo International Military Tribunal; the Generation-II focuses on the formation of the Transitional Justice bodies starting from Uganda (January 1974) to the beginning of 21st century; the Generation-III delves into the formation of the International Criminal Court in 2002 (Rome Statute of the International Criminal Court, July 17, 1998); the Generation-IV initiates from 2001 to 2019 which includes Non-state to Non-State conflict in the USA, Canada, Sri Lanka, and the Generation-0 centers the Peace Agreement, government and political parties who vow to form the Truth Commission time and again, but it is yet to be established.

The division of TJ Generations is carried out following the universality, indivisibility, interdependence and interrelatedness of human rights and human security (Pathak, February 2013). Likewise, required information and literature are gathered through networking tracking methods or snowball techniques. The information and literature are mostly reviewed to lesson-learned from yesterday, investigate the axiomatic truth for justice for today and encourage the hope to heal the wounds of the victims or survivors for better tomorrow. 


\section{GENERATION-I: A NOTION CHANGED FROM HOLOCAUST TO RETRIBUTIVE JUSTICE}

The general notion of Generation-I leads to the need to analyze the Germany's Nuremberg Trials (1945-1946) and International Military Tribunal for the Far East (IMTFE) (1946-1948). Nuremberg trial is an allied military tribunal that brought war criminals under international laws and laws of war immediately after the Second World War (commonly referred as WW II). The IMTFE is known as Tokyo Military Tribunal that was established against the leaders of the Japanese Empire (International Military Tribunal for the Far East, January 19, 1946). These two tribunals marked a changing point of classical law doctrine to contemporary international law.

Shortly after Adolf Hitler captured the state-power being the Chancellor of Germany in January 1933, his Government initiated implementing Nazi policies designed to persecute German-Jews and enemies of the Nazi States (www.bbc.com/bitesize/guides/zwmdfrd/revision/1). The Nazi policies had been grown up violently over the decades that had increased state-sponsored killings of some 5.7 million European Jews along with over 4 million non-Jews during WW II (Bauer, 1978). Hitler had not been the first State-leader who practiced enforced disappearances and extrajudicial killings to repress his political opponents. Stalin regime also followed the same methods against his rivalries (Vranckx, 2006).

In December 1942, the Allied nations' leaders such as Great Britain, the United States and the Soviet Union and their path-followers officially issued the first joint declaration. The declaration declared that the perpetrators responsible for violence against civilian populations (mass killings of European Jewry) should be prosecuted. Soviet leader Joseph Stalin initially proposed the execution of 50,000 to 100,000 German officials, but British PM Winston Churchill opposed the possibility of summary execution without a trial of highranking Nazis. However, American President Franklin Roosevelt argued that a criminal trial would be more effective (United States Department of State, 1945; Conot, 1983). The trial proceedings had both merit and demerit. The demerit is that the accusation proceedings require documentation of evidence crimes, charged against the perpetrators (defendants) and merit is that the proceedings can be done without evidence and testimonies.

In April 1942, representatives from the nine countries (USA, United Kingdom, France, Soviet Union, Germany, Switzerland, Austria, Belgium and the Netherlands) (Gaiba, 1998) occupied by Germany held a meeting in London and drafted the Inter-Allied Resolution on German war crimes. And, the meetings in Tehran (1943), Yalta (1945) and Potsdam (1945) agreed on the format of punishment for those responsible for war crimes during WW II. The legal basis for the trial proceedings was established based on the London Charter of the International Military Tribunal (IMT). It was approved upon by the four so-called Great Powers (France, Great Britain, the Soviet Union and the US on August 8, 1945 (Lawrence, 1947).

Article 6 of the London Charter has provisioned to charge both men and women on four disciplines: Crimes against Peace (planning and making war violating international agreements), War Crimes (violation of customary laws, treatment of civilians and prisoners of war), Crimes against Humanity (killing, enslavement, deportation to civilians and racial persecution) and conspiracy to commit other crimes. The Charter had been applicable to all including civilian officials and military officers who had been responsible for the holocaust.

The Nuremberg trial is the best-known as the Trial of Major War Criminals, held for 11 months and 19 days from November 20, 1945 to October 1, 1946 (Department of State Bulletin, October 21, 1945). The format of the trial had been a mix of legal traditions: prosecutors and defense attorneys, but the decisions and sentences had been imposed by a 
panel of judges of the tribunal rather than a single judge and a jury. Each of the four Allied power nations (France, the Soviet Union, the United Kingdom, and the United States) (history.state.gov/milestones/1945-1952/nuremberg) supplied two judges: first, the main judge and second, an alternate judge (IMT, October 1946). Justice Lawrence of the United Kingdom had been appointed as the President of the Tribunal and Tribunal authority had been unchallengeable (McKeown, 2014). Likewise, Article 16 of the Charter has protected the due process rights of the accused (Nuremberg Trial Proceedings, November 21, 1945).

The city of Nuremberg is the German State of Bavaria (less influenced area of WW II) which had been selected as the location for the trials where leading (high-ranking) representatives of the Nazi regime such as party, administration, security forces, medical and legal professionals compelled to answer having past wrongdoings (crimes) in front of the International Court of Justice (International Military Tribunal, 1947). That place had been chosen as a Palace of Justice which had been relatively undamaged by the war crimes and included a large prison area. The Palace of Justice is also marked as the symbolic end of Hitler's autocratic regime, the Third Reich (Shirer, 1960). The IMT's trial for the main war criminals had been held in Court Room 600 at the Nuremberg Palace of Justice (International Military Tribunal, 1947). Similar trials were held in Japan and Italy, too. Twelve follow-up trials were also held there between 1946 and 1949 (International Military Tribunal, 1947).

A total of 24 policymakers (high-ranking political leaders) and policy implementers (military officials) were indicted along with six Nazi organizations. Six organizations ie, the leadership of the Nazi party, the Reich Cabinet, the Schutzstaffel, General Staff and High Command of the Army, the Gestapo and the Sturmabteilung were determined as criminal organizations (Fraser, 2017). Among 24 indicted individuals, Hitler and two of his top associates namely Heinrich Himmler and Joseph Goebbels committed suicide before they could be brought to trial. One of the indicted men had been medically unfit to stand trial, another indicted man was killed himself when the trial began. Twelve accused were sentenced to death (hanged till death), seven received prison sentences ranging from 10 years to life imprisonment and one had been in absentia (Solsten, 1995) on October 16, 1946. Hitler's promoted successor Hermann Göring, head of the German air force, committed suicide by cyanide capsule the night before his execution (Henkel, 2011 and Editor 2001 and 2007).

On October 16, 1946, they were given death sentences by hanging not using the standard drop method instead of the long drop, but the US soldiers denied claims. The short drop length had been caused to condemn on the course to die slowly from strangulation instead of quickly (Time Magazine. October 29, 1946). Some of the condemned men died (agonizingly) slowly, struggling for 14-28 minutes before finally choking to death (Flagpole Magazine, 17 July 2002). The defendants were allowed to choose their own lawyers for their defense against the crimes, but criminalized actions committed before the laws were drafted (Nuremberg Trials, Undated).

Between January to July 1946, the defendants and several witnesses were interviewed by American psychiatrists (Goldensohn, 2004). The accusers had been successful in unveiling the outbreak of World War II where more than 40 million lives in Europe alone (Testa, Lemoine \& Strickland, 2003) were taken during the atrocities of the Hitler regime.

Of the 185 people indicted in the subsequent Nuremberg trials (1946-1949), 12 accused received death sentences, 8 others had been verdict life in prison and an additional 77 people received prison terms of varying lengths. However, the concerned authorities later reduced the number of the sentences (Nuremberg Trials, Undated). 
The Nuremberg Trial has been a step forward to establish the principles of international laws. They are: Universal Declaration of Human Rights (1948), United Nations Genocide Convention (1948), Geneva Convention on the Laws and Customs of War (1949), International Court of Justice (1945) and International Criminal Court (2002). Besides, the International Military Tribunal had been a useful model for the trials of Japanese war criminals in Tokyo (1946-48), the trial of (Nazi leader) Adolf Eichmann in 1961, war crimes tribunals in the former Yugoslavia (1993) and in Rwanda (1994).

The Nuremberg Trial has been controversial on the course to punish the major criminals of WW II. Harlan Stone, Chief Justice of the U.S. Supreme Court described the proceedings of the Nuremberg Trial as a "sanctimonious fraud" and a "high-grade lynching party" to Germans (Mason, 1956). After the conclusion of the Nuremberg trial, the U. S. Political Scientist Quincy Wright objected how the Nuremberg trial has obtained jurisdiction to find Germany guilty of aggression, when Germany had not consented to the Tribunal and how could the law (Nuremberg Charter) bind the defendants in the trial when they committed the acts years earlier (April 1948).

In October 1945, having the weakness of the trial, Robert H. Jackson, Chief United States Prosecutor writing a letter to the then US President Harry S. Truman said, "Allies themselves have done or are doing some of the very things we are prosecuting the Germans for. The French are so violating the Geneva Convention in the treatment of prisoners of war [...]. We say aggressive war is a crime and one of our allies asserts sovereignty over the Baltic States based on no title except conquest" (Luban, 1994). US Associate Supreme Court Justice William 0. Douglas charged that Allies were guilty of "substituting power for principle" at Nuremberg and Nuremberg trials were unprincipled (Thompson and Strutz, 1983). US Deputy Chief Counsel Abraham Pomerantz resigned protesting the low caliber of the judges assigned to give a trial to the industrial war criminals (Ambruster, 1947). Professor A. L. Goodhart at Oxford University opposed stating that judges were appointed partially, the Tribunal was not neutral and could not be regarded as a court in the true sense (Goodhart, April 1946). The IMT had not been a binding treaty as there had not been signatories. That just addressed based on the judgment of war crimes and crimes against humanity (Yale Law School, 2008).

The Tribunal itself got disputed as London Charter had been an ex-post facto law. The validity of the Tribunal had been questioned on a number of grounds such as rules of evidence (Art. 19 and 21). There had not been defendants' provision of appeal. Rather being a watershed of modern law, the Nuremberg had been an example of high politics masquerading as law, and then the trial instead of promoting may retard the coming of the day of world law (Wyzanski, April 1946). A contemporary German jurist stated that justice is not served when the guilty parties are punished in any old way. Justice is only served when the guilty are punished in a way that carefully and conscientiously considers their criminal errors according to the provisions of valid law under the jurisdiction of a legally appointed judge (Pendas, 2005).

The Chief Soviet prosecutor submitted false documentation stating that Germany murdered thousands of Polish soldiers in the Katyn forest. However, the other allied prosecutors refused to support German lawyers. None of the Germans were charged or found guilty at the Nuremberg Trial for the Katyn Forest massacre (BBC, April 28, 2010). In 1990, the Soviet Government acknowledged that more than 20,000 Polish soldiers were massacred in the Katyn forest by the Soviet secret police, not by the Germans at the start of WW II (BBC, December 16, 2004). It is very pity that Americans dropped the atom bomb and the British destroyed the cities of western Germany, but the Trial did not hear the plea of the Germans (The Economist, October 5, 1946). 
The secret agenda of all nations was to prosecute and punish the Germans so that it would not rise and boast of being a powerful country again, rather than to ensure free, fair and independent investigation and provide fair justice to them. It had happened owing to the vested interest of international politics.

Tokyo International Military Tribunal: In July 1945, President of the United States, the President of the National Government of the Republic of China and the Prime Minister of Great Britain signed the Potsdam Declaration that delivered straight path to Japan for unconditional surrender to initiate stern action in the name of justice that meted out to all war criminals (Potsdam Declaration, July 26, 1946). When the Potsdam Declaration had been signed, the war in Europe had ended but the war with Japan had been continuing (Japan Institute of International Affairs, March 2014). However, the Soviet Union did not sign the Declaration till August 8, 1945, that the United States dropped the second atomic bomb at Nagasaki. Finally, Japan surrendered six days later, the six atomic bombs dropped on August 14, 1945 (Butow, 1954).

Unlike the IMT, the Tokyo Military Tribunal had emerged from international agreements to prosecute and punish the Japanese war criminals (International Military Tribunal for the Far East, January 19, 1946). The IMTFE had been established by a special proclamation of the US Army General Douglas MacArthur, Supreme Commander for the Allied Powers (SCAP) on January 19, 1946 (Kaufman, 2013). MacArthur had been granted authority to issue all orders for the implementation of the Terms of Surrender, the occupation and control of Japan, and all supplementary directives (German Instrument of Surrender, May 8, 1945). On September 2, 1945, Japan signed the Instrument of Surrender who had agreed that war criminals would be brought to justice (MacArthur, 1994). Like the Nuremberg Charter, autocratic power-holder MacArthur laid out the composition, jurisdiction and function of the Tribunal.

On February 15, 1946, MacArthur appointed eleven judges to the IMTFE on behalf of the countries who had signed Japan's instrument for surrender. The signatories were: Australia, Canada, China, France, British-India, the Netherlands, Philippines, the Soviet Union, the United Kingdom, and the United States. Each of these countries had been a separate prosecution team member (Kaufman, 2010).

The jurisdiction of the IMTFE had been to try individuals for Crimes against Peace, War Crimes and Crimes against Humanity which define verbatim those contained in the Nuremberg Charter. The IMTFE had jurisdiction over crimes that happened from 1931 Japanese invasion of Manchuria to Japan's 1945 surrender (Madoka, 2008).

The Tokyo War Crimes Trials held from May 1946 to November 1948. Following the precedent of the Nazis, the IMTFE established three-broad criminal categories: (i) Class A (Crimes against Peace) or policy-makers, (ii) Class B (Conventional War Crimes) or policy-supervisors and (iii) Class C (Crimes against Humanity) or policy-implementers (Tanaka, McCormack, \& Simpson, 2011). A total of 28 personnel including 18 military officials and 10 political leaders had been charged with class A who were responsible for planning, preparation and initiation or waging of a war of aggression violating international law and treaties (Timothy, 1952). The class B violated the laws or customs of law. The class $C$ involved in murder, enslavement, deportation, and other inhumane acts committed against the civilian population, before or during the war. More than 5,700 Japanese nationals were charged with Class B and C crimes on the course of entailing prisoner abuse (Dean J. Alton Hosch: More About the IMTFE, Undated). 
The Tribunal for the Class A defendants conducted over 900 sessions which collected 4,356 pieces of documentary evidence and testimonies of nearly 1200 witnesses. Each defendant had been allowed three or four attorneys to help them for the purpose of their defense (Neil \& Cryer, 2008).

The defendants included former Prime Ministers, former Foreign Ministers and former Military Commanders of various ranks and files. However, Japanese Emperor Hirohito and other imperial family members had not been indicted. Hirohito retained his position on the throne, albeit with diminished status. The IMTFE found many defendants guilty and sentenced them to punish ranging from death to seven years' imprisonment, whereas two defendants died during the trials. In Japan, several additional trials took place in cities outside Tokyo. A few allies such as Australia, Canada, India, and the Netherlands had been willing to see some reductions in sentences (Wilson, Cribb, Trefalt, \& Aszkielowicz, 2017).

The USA had been the controlling roles in both Tribunals. It means, it had provided Chief Prosecutor, staff and necessary funds for running the Tribunals. There is a historical impression that USA never pursues free, fair and impartiality. Because of American bias and vested political interest of superpower, Tribunals had had no more means for the acceptance of perpetrator's or victor's justice. The USA tries hard to impose colonialism, i.e., atomic bombings in Hiroshima and Nagasaki. The bombings in Hiroshima and Nagasaki were war crimes even under the 1907 Hague Convention. Tribunals had not little more been than a sword in a judge's wig. There was no customary international humanitarian law applied before WW II. The indiscriminate bombings in Chinese cities by Japanese Imperial Forces and USA bombings in Japanese cities had never been raised in the Tokyo Tribunal fearing the USA's hazardous interest and encroachment.

Japanese Emperor Hirohito including other members of the Imperial Family has been regarded as a potential suspect to establish the Tribunal (European Journal of International Law, November 2010). Even after Japan's surrender, Hirohito had not been prosecuted for war crimes similar to many other leading government figures (Dower, June 2000).

The Nuremberg and Tokyo Tribunals are now regarded as a milestone toward the establishment of a permanent International Court to deal with genocide and other grave human rights violations. Till the end of the 20th century (1940s-2000s), those tribunals became the only examples of international war crimes Tribunals. The reference to "crimes against peace," "war crimes," and "crimes against humanity" are used and defined in today's international legal instrument.

A number of suspicions are there whether the Hitler was summarily executed by the US forces or CIA trained soldiers clandestinely as an act of political revenge similar to rebel leader Che Guevara (Ryan, 1998) without proper testimonies and evidence and the same US soldiers allegedly spread the rumor that Hitler committed suicide himself. The USA forces not only dominated the entire allied powers but initiated a cruel, inhumane and degrading treatment to the opponents and never heard the real pleas of the German and Japanese citizens. Moreover, the USA had provided the funds and necessary staff for running the Tribunals and also wholly leads the Tribunal.

This Generation-I shows clear ways of political retaliation: holocaust to retribution rather than conducting free, fair and impartial justice in both Nuremberg and Tokyo Tribunals. Holocaust donates destruction or murder on a large mass scale, whereas retributive justice is a response to a crime which is proportional to the offender's offense. In other word, retributive justice is a 
return of s/he suffers in. Both Tribunals were highly influenced by the military doctrine and revenge politics, no truth for justice was granted to the inducted perpetrators in both Germany and Japan. The allied forces are already determined about punishing the perpetrators. Meanwhile, some pseudo Tribunals were formed just to show the entire world that allied forces conducted Transitional Justice process to prosecute and punish the perpetrators. The Generation-I tends to give the best response 'crime is a punishment' that proportionate to his/her offense. Retributive holds that if an offender breaks the law, justice requires that (he/she) suffers in return similar to ancient Jewish cultural justice, 'tit for tat': 'life for a life', 'eye for an eye' and among others.

\section{GENERATION-II: A NOTION CHANGED FROM INTERNECINE WAR CRIMES TO HUMANITARIAN JUSTICE}

More than 60 transitional justice bodies (Truth Commissions) have already been established across the continents. A Truth Commission is formed to discover and reveal the past wrongdoings (legacies of human rights violations or abuses) either by a Government or nonState actors applying judicial and non-judicial measures. On the hope of resolving or transforming internecine conflict, number of countries has established Truth Commissions.

They are: (i) Africa (25): Algeria (Kristianasen, 2006), Burundi (Wielenga, February 2015), Central African Republic (IRIN, October, 62003), Chad (Human Rights Watch, July 2005), DR Congo (United States Institute of Peace, July 1, 2003), Eretria (Voice of Eritrean Woman, October 30, 2016), Ethiopia (United States Institute of Peace, January 1, 1993), Gambia (Amnesty International, January 7, 2019), Ghana (Migyirka, 2008), Ivory Coast (Country: Ivory Coast, Online), Kenya (Kenya Transitional Justice Network, August 2013), Liberia (Sirleaf, Undated), Mauritius (United States Institute of Peace, February 9, 2012), Morocco (Human Rights Watch, November 2005), Namibia-demanding more than 2 decades (Lela, March 26, 2019), Nigeria (Yusuf, August 10, 2007), Rwanda (Schabas, 2006), Sierra Leone (International Center for Transitional Justice, Undated), Solomon Islands (Jeffery, January 7, 2017), South Africa (Truth and Reconciliation Commission, 1998), South Sudan-demanding (UN Human Rights Council, September 17, 2018), Togo (Sarkin \& Tetevi, April 4, 2017), Tunisia (UNDP, June 9, 2014), Uganda (International Center for Transitional Justice, September 2012), and Zimbabwe (Plessis \& Ford, January 2009).

(ii) America (17): Argentina (Crenzel, July 2008), Bolivia (Human Rights Watch, December, 1992), Canada (Statement of apology to former students of Indian Residential Schools, June 11, 2008), Chile (United States Institute of Peace, October 4, 2002), Colombia (COHA, November 1, 2011), Ecuador (United States Institute of Peace, May 3, 2007), El Salvador (TRIAL, 2016), Guatemala (Corntassel \& Holder, 2008), Haiti (Quinn, August 18, 2009), Honduras (Amnesty International, May 1992), Mexico (Agren, December 3, 2018), Nicaragua (Vivanco, May 14, 2018), Panama (Panama: Truth Commission Delivers its Final Report on Victims of the 19681988 Military Regime, May 2, 2002), Paraguay (US Department of State, 2007), Peru (Cueva, 2004), United States of America (Jovanovic, 2012), and Uruguay (Allier, October 2006).

(iii) Europe (13): Balkans [ie, Bosnia-Herzegovina (Fischer, 2007 \& Sverrisson, January, 2006), Croatia, Kosovo, Macedonia, Montenegro (Zupan, 2006 \& Milekic, July 10, 2018), Serbia and Slovenia] (Kostovicova, July 20, 2018), Cyprus (Ladisch, Undated), Germany (Human Rights Watch, 1995), Georgia (ICC-01/15), Russia-demanding (Historical Truth Commission); Albania-demanding (Mejdini \& Ristic, March 1, 2018) (atrocities happened in communist regime); Armenia-demanding (Carranza, November 9, 2018) (atrocities happened in communist regime), and Czech Republic-demanding (atrocities happened in communist regime). 
(iv) Asia-Pacific (12): Australia (Reconciliation, May 10, 2018), Bangladesh (Bangladesh, July 20, 1973), Cambodia (Ngarm, 2017), Fiji (International Bar Association, 2005), Indiademanding, Indonesia (The Center for Justice and Accountability, Undated), East-Timor (Beigbeder, 2011), Nepal (Pathak, August 29, 2015), Pakistan-demanding, Philippines (ICC, February 8, 2018), South Korea (Charles \& Chang, August 4, 2008), and Sri Lanka (The Gazette of the Democratic Socialist Republic of Sri Lanka, Undated).

There have been high demands to establish truth commissions in Middle East (7) countries. They are: Egypt, Jordan, Iran, Iraq, Lebanon (ICRC, July 1, 2016), Libya, and Kuwait. It is to be noted that Canada, Sri Lanka and the United States of America fall in the category of Generation-IV. Brief case studies of the Truth Commissions regarding transitional justice in the Generation-II have been given below.

\section{ii. African Truth Commissions}

Algeria: Algeria's Ad Hoc Inquiry Commission in Charge of the Question of Disappearances investigated past crimes and identified and determined the fate of people who were disappeared on the civil conflict from 1992-1999 and drafted a reparations plan for the families of the disappeared (United States Institute of Peace, September 21, 2003). However, the Commission worked more focusing as a 'management center' between families of the disappeared and the Algerian public administration rather than a Commission of investigation (Arnould, May 30, 2007). For the purpose to lead peace through reconciliation and justice, the Charter on Peace and National Reconciliation was approved (The Economist, October 6, 2005). This Charter granted amnesty to murderers and criminals despite huge public pressure to provide justice to the victims. The central theme of reconciliation and amnesty had been forgiveness.

Burundi: The TRC created in May 2014 to investigate the interethnic conflicts that began when Burundi became independent from Belgium in July 1962. At first, it had a mandate to investigate the past crimes from July 1992 to December 2008. However, the Government extended its period to cover for 123 (1885-2008) years. The TRC officially started its work in March 2016 (Rugiririza, November 1, 2018) and also see the United States Institute of Peace, January 13, 2004). Recently, the TRC calls for women and girls to share their experiences (ICTJ, April 14, 2019). It also calls for multi-faceted support from the international communities (John, January 31, 2019) to accomplish their tasks.

Central African Republic (CAR): On February 6, 2019, the CAR Government and 14 armed groups signed an agreement to set up a Truth, Justice, Reparation and Reconciliation Commission within 90 days (Oteng, February 8, 2019). During 18 months of talks with the groups, a total of 1.2 million people were displaced (2015-2018). However, the armed rebels are seeking a blanket amnesty (Human Rights Watch, February 22, 2019).

Chad: Chad established the Commission of Inquiry into the Crimes and Misappropriations Committed by Ex-President Habré, His Accomplices and/or Accessories to investigate the killings, disappearances, tortures and other forms of gross human rights violations. Chad has also been the first Commission including illicit narcotics trafficking committed during 19821990 (Farah, November 27, 2000). Chad's Habre is known as the African Pinochet (Searcey, May 30, 2016). The report documented that approximately 40,000 people were extra-judicially killed (United States Institute of Peace, December 29, 1990) and 200,000 cases of torture committed by the Habre where the perpetrators were trained by foreign governments (Commission of Inquiry, May 7, 1992). 
DR Congo: The Truth and Reconciliation Commission established from July 2003 - February 2007 to investigate and promote national unity in response to the war crimes committed in the armed conflict among the Congolese army, Congolese rebels and foreign insurgents (Naughton \& Reátegui, 2016). The 4 years operated report was 84 pages long, without concrete findings, though. Because of the limited investigation, no names of victims, perpetrators and witnesses were included in the report (United States Institute of Peace, July 1, 2003). There has been a high demand to form Commission II, but in vain.

Ethiopia: The Ethiopian Government formed the Truth and Reconciliation Commission on February 12, 2019 headed by Archbishop, President of the Council of the Ethiopian Church (CM Communications, February 25, 2019). The Government should consider the effective approach to investigate and prosecute, but victims have a fear whether they will achieve access to justice fairly, independently and credibly (Human Rights Watch, April 8, 2019).

Gambia: The Truth, Reconciliation and Reparations Commission (TRRC) was established by the Gambian Government on October 15, 2018 to investigate human rights violations and abuses during the 22-year (1996-2017) dictatorship of former President Yahya Jammeh. The hearings started on January 21, 2019 in the capital Banjul (AI, January 7, 2019). The TRRC has been the sixth Truth Commission launched in Africa in its history (Asemota, 2018, October 16). The TRRC was welcomed by the international community, mainly the United Nations (October $15,2018)$.

Ghana: Ghana established the National Reconciliation Commission to investigate human rights violations and abuses: killings, disappearances, abduction, torture and among others. It had happened during the unconstitutional government from March 6, 1957-January 6, 1993 (Valji, September 2006). It conducted more than 2,000 public hearings to conclude the process. The Commission collected testimonies from 2,129 victims where 79 were identified as perpetrators. The perpetrators included former President John Jerry Rawlings, Ex-National Security Advisor and senior army officials (Ghana National Reconciliation Commission, 2004). Law enforcement institutions-armed forces were responsible for the highest percentage of human rights violations or abuses. A comprehensive reparation package including a public apology, memorial and monetary compensation for 3,000 victims were recommended, but resulted in implementation failure due to the lack of funding (Odartey-Wellington \& Amin, 2006). The final report was submitted in October 2004 and the Government of Ghana made it public in April 2005 (United States Institute of Peace, January 14, 2003).

Ivory Coast: The Dialogue, Truth, and Reconciliation Commission was established by the President on September 28, 2012 to investigate human wrongdoings that occurred in the postelection violence during 2010-2011. The 11-member team was led by the former Prime Minister of Ivory Coast modeling the South African TRC (Fombad, 2017). The Commission submitted its report in December 2014, but the report has not yet been made public (Human Rights Watch Report, 2014). The Government created the National Program for Social Cohesion to execute the reparations program and policy (October 25, 2015).

Kenya: The Truth, Justice and Reconciliation Commission of Kenya (TJRC) was established in 2008 to investigate the gross human rights violations or abuses owing to liberation struggles as well as ethnic conflicts, semi-despotic regimes, marginalization, political violence and the 2007 post-election violence (Gettleman, January 31, 2008; Kenya, 2013; Roberts, September 2009; Kenyans for Peace with Truth and Justice, 2010). The Commission conducted individual public/private hearings, thematic hearings and institutional hearings. The Commission 
explained the causes of violations and recommended to prosecute the perpetrators and reparations for the victims (Kenya Transitional Justice Network, August 2013).

Liberia: The TRC of Liberia was established with a working plan for October 2005 to September 2008, but changed its date later (United States Institute of Peace, February 20, 2006). The final report presented at the parliament in May 2014 had collected 42,465 statements and 1,828 memoranda from the victims (Ndungú, May 2014). A total of 124 perpetrators including 8 leaders were recommended for prosecution where 38 perpetrators were pardoned for minor crimes, and amnesty was granted to all former child combatants. Dialogues were initiated for justice and reconciliation in the countryside. The Extraordinary Criminal Court was established for prosecution and Reparation Trust Fund was established. The TRC suffered from a limited budget, officials, time for hearings, sufficient infrastructures and others (Aning \& Jaye, April 2011). The rebel leader Charles Taylor influenced the TRC and the Supreme Court for not providing testimonies about Taylor's trial (United States Institute of Peace, February 20, 2006). The Commission threatened the government of submitting its findings to the ICC (International Criminal Court) if the government failed to establish the tribunal.

Mauritius: Unlike many other Truth Commissions, Truth and Justice Commission of Mauritius registered the complaints of the dispossession of land from the descendants of slaves and indentured laborers. It attempted to cover the period of 370 (1638-2008) years (Mauritius, November 2011; Allen, 1999). Mauritius Commission documented the impacts of economic colonization, slavery and indentured servitude and working condition of sugar estates (Truth and Justice Commission, November 2011). The report recommended memorializing slavery: inclusive history culture, prioritizing social equality (less racist and elitist society), encouraging democratic public life and increasing economic and social justice (United States Institute of Peace, February 9, 2012). Financial compensation was an appropriate recompense for their and their ancestors' suffering for social reform, but report recommendation could not be implemented due to little public pressure to the Government (Croucher, Houssart, \& Michel, undated).

Morocco: Moroccan Equity and Reconciliation Commission documented the fates and whereabouts of 742 enforced disappeared persons, but did not mention individual or institutional perpetrators responsible for such grave human rights violations or abuses (United States Institute of Peace, December 1, 2004). Even on the public hearings, victims signed an agreement not to identify individual or institutional perpetrators. The financial, medical and psychological reparations were distributed between 9,000-16,000 victims within 18-month (Hayner, 2011). However, 250 staffs from both the government and NGOs were mobilized for community reparation programs (International Center for Transitional Justice, 2009). Economic compensation, medical care and vocational trainings were provided to the victims and families. Perpetrators continued to hold high-level of government positions (Chaouki, June 2004). However, the victims remained unsatisfied as the government denied providing reparations on past crimes occurred during the reign of Hassan II.

Nigeria: The mandate of Human Rights Violation Investigation Commission (The Judicial Commission for the Investigation of Human Rights Violations) of Nigeria was to scrutinize the cause, nature and extent of human rights violations, including extrajudicial killings, enforced disappearances (United States Institute of Peace, June 14, 1999). Digging the truth, the Commission identified and determined the role of the perpetrators during January 1966-May 1999 (Amnesty International, December 2000). The Nigerian Commission documented 10,000 complaints of victims, but only 150 (1.5\%) emblematic cases were publicly heard, 
approximately 35 cases forwarded to the police headquarters for further investigations, the remaining were sent to a ministerial commission for settlement. It recommended for reparations. The concerned Ministers attempted to protect the perpetrators. The victims were recommended for compensation (Yusuf, 2007). Nine bodies were exhumed from the gravesites in 1999 but the report, which recommended to reform security forces and their academic institutions, was never officially published (United States Institute of Peace, June 14, 1999)).

Rwanda (permanent body): The Rwandan National Unity and Reconciliation Commission established in March 1999 became a permanent body in November 2002 (Republic of Rwanda, Undated). The purpose of the Commission was to promote unity and reconciliation between Hutus and Tutsis genocide. While incumbent President Habyarimana was assassinated in 1994, the genocide sparked over 100 days that killed an estimated 500,000 to 1,000,000 people (United States Institute of Peace, March 1, 1999). The Commission report revealed that political and socio-economic issues were more responsible for the divisions and fundamental differences between Hutus-Tutsis. The bad governance, the culture of impunity and social injustices played a pivotal role in such successive ruling cliques (Manga, 2008). The International Criminal Tribunal for Rwanda (ICTR) and domestic trials were initiated only after the 1994 genocide. The Commission, however, did not recommend for prosecutions.

Sierra Leone: The TRC of Sierra Leone investigated the cases of human rights violations (1991-2002) to seek justice for victims who had suffered from atrocities in the past (Thapa, 2017). It aimed at recommending the policies to facilitate reconciliation and prevent future violations (Kelsall, May 2005). Loma Accord (ICTJ, 2010) had a mandate of a blanket amnesty to the perpetrators through the Disarmament, Demobilization and Reintegration (DDR) program (Pathak, September 13, 2011). Disagreeing with the DDR program, Revolutionary United Front abducted 500 UN Peacekeepers in 2000 (Thapa, 2017). During the armed conflict, children as young as 8-year old were recruited as soldiers and girls were forced either to be domestic servants or sex slaves (Human Rights Watch, 2000).

The Commission submitted its report to the President on October 5, 2004 and the President presented it to the UN Security Council on October 27, 2004. There had been a legal binding authority on the recommendation of the report. Both forces were found responsible for human rights violations against civilians (United States Institute of Peace, November 1, 2002). Its recommendations were to fight against corruption, creation of a new bill of rights to the constitutional process, strengthening the parliament, independence of the judiciary, control over security forces, the inclusion of youth and women in decision-making process, among others. The TRC and the UN sponsored a War Crime Tribunal (Special Court for Sierra Leone) following Loma Accord (Migyirka, 2008). The National Commission for Social Action was formed focusing on reparation programs (Hayner, December 2007). However, it was slow functioning and unsuccessful in collecting the statements from all the victims and perpetrators with insufficient funding and time contributing to inadequate recommendations, especially on reconciliation (Thapa, 2017).

Senegal: Since Chadian President Hissène Habre was chased from power in 1990, he took shelter in Senegal. Truth Commission report concluded that Habre was found guilty of 40,000 political murders, 200,000 cases of tortures, dozens of rapes and among others. In July 2006, Senegal announced to prosecute Chadian President Hissène Habre in Senegal for serious human rights violations and/or abuses during his regime (1982-1990) (Hayner, 2011) in Chad. In August 2008, Habré was convicted (in absentia) for crimes against humanity and sentenced to death by Chad's Criminal Court (United States Institute of Peace, December 29, 1990). Belgium pressured the International Court of Justice (ICJ) to force Senegal either to extradite 
Habré to Belgium or to proceed with the trial, but the request was denied by the ICJ (Morgan, May 28, 2009). Moreover, the African Union urged Senegal to extradite Habré to Belgium in June 2011 (Global Legal Monitor, July 21, 2015). Habre was arrested by the Senegal police on June 30, 2013 (Nossiter, June 30, 2013) and he was sentenced to life imprisonment by the African Union-backed court (Amnesty International, Undated). Thus, Habre became the first former ruler of the case that one country's court prosecuted another country's ruler for crimes against humanity (BBC, May 30, 2016).

Solomon Islands: Solomon Island's TRC was established to investigate the causes of ethnic violence from 1997-2003. The TRC concentrated its works on promoting national unity and reconciliation for not repeating such ethnic conflicts (United States Institute of Peace, April 29, 2009). The Commission was the first of its kind in the Pacific Islands region (RNZ, April 30, 2009). The public hearing started in March 2010. The inclusion of youth hearings at the TRC provided with a forum to construct their justice narratives, distinct from children (Mollica, January 7, 2017). The TRC demonstrated the idea that societal reconciliation was not possible without State-level forgiveness. The victims' community explicitly opposed amnesties for excombatants arguing that without justice, forgiveness alone was unlikely to achieve reconciliation. Many ex-combatants hoped to benefit from the proposed amnesty laws, but that went in vain (Jeffery, January 7, 2017). On April 28, 2013, the final report was unofficially released (fearing of ethnic tension). However, the report did not provide enough space to forgive the perpetrators and forget the victims (Cain, May 1, 2013).

South Africa: The TRC of South Africa investigated serious human rights violations or abuses: disappearances, killings, or torture; those were perpetrated during the 30 years Apartheid regimes (March 1964-May 1994) (United States Institute of Peace, December 1, 1995). Controversially, the TRC was set up to grant amnesty to the perpetrators (Boraine, 2001). The TRC completed its task in seven years (United States Institute of Peace, December 1, 1995), which collected approximately 21,000 cases of testimonies where 2,000 (9.5\%) of them attended at public hearings. No initiatives were taken to collect statements, testimonies and evidence from the victims of the countryside. The Report stated that it received 7,112 amnesty applications in which 849 (12\%) cases were granted amnesty, but 5,392 (74\%) were refused. Remaining 1,015 (14\%) were withdrawn (United States Institute of Peace, December 1, 1995). The documents and testimonies were massively destroyed during 1990-1996 by the security forces. Some powerful perpetrators including former Prime Minister P. W. Botha, senior army generals and senior leaders did not attend the public hearings despite repeated invitations. However, all perpetrators were controversially granted amnesty from both the civil and criminal prosecutions despite TRC's recommendation against it (ICTJ, Undated). Former Prime Minister Hendrik F. Verwoerd, the mastermind of apartheid said, "The white are the creators of the universe". Reparations still continues (Greiff, 2006) in the lack of budget allocated by the Government. Thus, the voices of the victims for justice and reparation were crushed.

Togo: Togo Commission examined broad historic patterns of human rights violations or abuses during the dictatorial rule that started in 1958 and continued till the first-post independence election in 2005 (Sarkin \& Tetevi, April 4, 2017). The final report of the Commission was submitted (Domegni, 2016), but the Commission did not have the mandate to analyze the electoral violence of 2005 and 2011 where hundreds of people were killed (Worldwide Movement for Human Rights, 2011). The perpetrators were not testified. The alleged perpetrators did not attend the interrogations.

The Commission had a duration of 18-months, which was later extended up to 38 months. However, the final three reports were submitted after 53 months only. The Commission 
provided 68-recommendations and based on the recommendations, the Government has created the High Commission for Reconciliation and Strengthening of National Unity (Rwanda, May 31, 2016). Togolese transitional justice is little known because it is under-researched (Sarkin \& Tetevi, 2017).

Tunisia: The Truth and Dignity Commission was set up in 2014 which collected a large number of cases of human rights violations in Tunisia (Amnesty International, March 25, 2019; Amara, March 27, 2019). The report of the Commission received over 62,000 submissions and heard testimonies from about 11,000 (18\%) people (ICTJ, November 17, 2016) only. The Commission held its 14 public hearings in Tunisia starting from November 17, 2016. A coalition of Human Rights Organizations defended the transitional justice process when it came under attack from the opponents inside and outside the government and boycotted by the Tunisian news media. The Commission recommended the creation of an independent body to oversee or monitor the work of the Tunisian security forces. The Commission complained that it suffered from lack of political will (The New York Times, March 28, 2019).

Uganda: The Ugandan Commission of Inquiry into Violations of Human Rights II (1986-1994) investigated extrajudicial killings, enforced disappearances, arbitrary arrests and detentions between 1962-1986 (Acirokop, 2012; Peterson, 2005). The report of the Ugandan Commission I has identified 308 cases of enforced disappeared persons. It recommended setting up a Public Security Unit and National Investigation Bureau to work for disappearances. However, the report was not made public. The first Truth Commission recommended to reform security forces and train them on human rights and humanitarian standards (United States Institute of Peace, June 30, 1974 \& TRIAL, February 12, 2016). However, the Ugandan Commission II recommended repealing the law that allowed detention without trial. It also recommended developing human rights education curricula in schools, university and training courses in the security forces. Public hearings were also conducted. The Commission was interrupted in 1987 owing to financial constraints (United States Institute of Peace, May 16, 1986).

Zimbabwe: The Zimbabwe Commission (1983-1984) investigated the killings of political dissidents and other civilians in the Matabeleland region and gathered testimonies from villagers (Hayner, 2001). The final report could not be produced fearing of sparking violence over human rights abuses. Against the Government's decision, two NGOs produced a report on Breaking the Silence, Building True Peace in 1997 (The Catholic Commission for Justice and Peace in Zimbabwe and The Legal Resource Foundation, October 2001) only interviewing the victims (Ball, April 15, 1998). The unofficial report documented that more than 2,000 people were killed by the state security forces. In addition, mass graves were discovered. It recommended establishing the National Peace and Reconciliation Commission that might offer a compensation package to the affected victims (United States Institute of Peace, September 1, 1983; Tshuma, September 18, 2018). In 1988, President Robert Mugabe granted a general amnesty to the ruling party cadres and security forces who were responsible for the massacre at Matabeleland (Carver, 1989).

\section{ii. American Truth Commissions}

Argentina: The National Commission on the Disappeared examined the facts of disappearance cases that happened during the dirty wars (1976-1983) (Argentine National Commission on Disappeared, 1986; Crenzel, July 2008). The final report of Argentina collected 8,960 cases of disappearance, but 10,000 to 30,000 victims were estimated (International Center for Transitional Justice, August 2005). A large number of victims did not register the complaints in the Commission fearing possible retaliation by the army. The then de facto President General ordered to destruct the testimonies or documents that could have proven them guilty within 
the army chain of command (Czitrom, January 2002). The Commission did not hold public hearings. Only 5 generals were imprisoned. The report recommended providing reparations to the victims; making judicial reforms; and giving human rights education to the army (United States Institute of Peace, December 16, 1983).

Bolivia: In the case of Bolivia, the National Commission for the Investigation for Forced Disappearances investigated enforced disappeared persons for the period of 18 years (19641982) when the military junta overthrew the elected President in 1964 (Hayner, 1994). The Bolivian Commission was terminated before the end of its tenure, however, 155 cases of disappearances were documented. The Commission identified some gravesites of the disappeared persons. No final report was produced after the commission was disbanded. Nonetheless, the former dictator Luis García Meza has been serving a 30-year prison sentence since 1995 (United States Institute of Peace, October 28, 1982).

Brazil: The National Truth Commission of Brazil formed in October 2011 investigated and compiled the facts of human rights violations or abuses of the military regime during 19641985 (Custódio, April 27, 2015). The Commission lasted for two years where people had an expectation to provide reparation to the victims (Hayner, 2011). Brazil decided to establish the Truth Commission in December 2009, but as the army threatened the then President Silva, that was postponed until the end of 2011 (Filho, February 2012). The Commission conducted 15 public hearings (Report of the National Truth Commission, December 10, 2014). The report stated that 434 people were either killed or disappeared by the actions of the military regime (Paulo, December 10, 2014). It identified 337 perpetrators (Taylor, December 10, 2014) and recommended for judicial action. It did not recommend for reparation in the lack of provision of it in the Statute. It had at first two years' tenure which was later extended for another 14 months. The report has 29 recommendations (Custódio, April 27, 2015) including the right to memory, truth and justice.

Chile: The Chilean National Truth and Reconciliation Commission focused its investigation on punitive human rights violations or abuses that occurred during the General Augusto Pinochet (1973-1989) regime (Quinn, 2001; United States Institute of Peace, October 4, 2002). The Chilean final report recorded 3,428 cases of violations including 979 enforced disappearances, 2,298 killings and among others. Most of the disappearances had taken place during 19731974 as a planned strategy for repression by the military government. Pinochet was arrested in Great Britain in 1998 on the charge of violating International Human Rights Law, but the Court granted him amnesty. Pinochet was kept under house arrest on the charges of corruption in 2004, but died in 2006 (Pathak, 2016). The Commission recommended establishing a National Corporation for Reparations and Reconciliation, Human Rights Legislation and Ombudsman. A second truth commission named the National Commission on Political Imprisonment and Torture was established in 2003 to investigate human rights violations which were not covered by the mandate of the 1990 Commission (Amnesty International, June 11, 2007).

Colombia: The Government and Revolutionary Armed Forces of Colombia (FARC) representatives agreed to conduct an investigation of the 50-year old conflict (Paterson, January 2016). A peace agreement signed between the Government and the FARC in June 2016. Following the agreement, the Colombian Government formed the TRC for three years to investigate the cases of more than 63,800 people who had officially been reported missing, where 45,154 persons were believed to be buried in mass graves (Soendergaard, December 16, 2013). Only 5,390 remains were found through exhumation. Out of 5,390, only 2,483 (46\%) were identified but merely 145 remains were returned to their families (International 
Commission on Missing Persons, Undated). More than 45,000 cases of complaint of disappeared persons were registered till May 2016, but indirect victims may go up to three times more. The National Institute for Forensic Medicine puts the total number of missing persons at 111,588 including more than 22,000 of these classified as forced disappearances, where men constitute 88 percent (United States Institute of Peace, July 2016)). Colombia is developing the Databank collecting DNA profiles from the families or relatives of missing persons (Flores, September 3, 2017).

Ecuador: In the case of the Ecuadorian Truth Commission I, 176 cases of gross human rights violations or abuses (1979-1996) were investigated and the report was submitted to the judiciary with evidence and to provide reparations to the victims (Hibbitts, May 6, 2007). But, the Ecuador Commission II examined the enforced disappearances, killings and tortures perpetrated during the 1980s with special focus on 1984-1988 students and social movements committed by the ex-President León Cordero (Amnesty International, October 1991). While the then President Abdalá Bucaram was removed by the Congress in February 1997 on accusations of corruption, the Commission I disbanded immediately. Consequently, the report did not get published. The Ecuadorian Commission II documented and reported 456 cases allegedly responsible for crimes against humanity. In early 2009 , the Commission II had called 200 alleged persons including security forces for public interaction, but only 40 percent attended (Hayner, 2011). Moreover, 155 recommendations were made centering on reparations: satisfaction, restitution, rehabilitation, compensation and (guarantees of) nonrepetition. It drafted a reparation law for victims in June 2010 (United States Institute of Peace, May 3, 2007). It was estimated that just 1 to 3 percent of the reported killings were punished (A/HRC/17/28/Add.2, May 9, 2011).

El Salvador: The El Salvadorian Truth Commission probed the cases of grave human rights violations or abuses during 1980-1992 and recommended methods of promoting national reconciliation (Buergenthal, October 1994). A total of 22,000 complaints were registered, where 60 percent involved extrajudicial killings, 25 percent disappearances, 20 percent torture and others. The State security forces were responsible for 85 percent and the non-state actors for 15 percent. It recommended dismissal of the army officers and civil servants who were responsible as the perpetrators. It also recommended an extensive judicial and legal reform (use of coerced confessions in trials) and security and institutional reforms. It recommended for reparations: memorials and monetary compensation (Burnett, November 13, 2008). The civilian Government and the security forces rejected the report, though 200 senior officials were removed from the army. While rumors spread of military coup, the Legislative-Parliament passed a general amnesty law (United States Institute of Peace, July 1, 1992).

Guatemala: The Guatemala Historical Clarification Commission (United States Institute for Peace, February 1,1999) studied grave human rights violations or abuses that occurred during 36 years (1960-1996) long internal conflict (Sieder, 2011). Guatemala security forces committed acts of genocide to the people of Mayan. About 200,000 including 83 percent from Mayan and 17 percent from Ladino were killed. The State was responsible for 93 percent of human rights violations or atrocities, but the armed insurgents were responsible for 3 percent (Rothenberg (Ed.), 2012). The Commission was not allowed to include the name of the perpetrators for prosecution in its report. Even though, in 2009, a retired colonel and three formal paramilitaries were prosecuted on the charge of enforced disappearances (United States Institute for Peace, February 1, 1999). Former military dictator Jose Montt was prosecuted for genocide and crimes against humanity (Lopez, January 11, 2016). Guatemalan 
army opposed the Peace Accord of 1996 fearing possible prosecution (Mersky, March 7, 2005). The Commission collected the truth-telling of the victims (Sieder, 2011).

Haiti: The Haitian National Truth and Justice Commission identified human rights violations or abuses that had taken place during the three-year period (September 1991-September 1994) where the elected President Jean-Bertrand Aristide was overthrown by the military coup d'état (Benedetti, 1996). The Commission report documented over 5,500 testimonies, examined 8,667 victims on sexual violence against women and other forms of human rights violations or abuses. It included the name list of alleged perpetrators and recommended for prosecution and over 50 perpetrators were prosecuted (United States Institute of Peace, April 1, 1995). The Supreme Court reversed sentences of 15 ex-paramilitary and FRAPH members (Quinn, August 18, 2009). The Commission had worked only for 5 months of its 12 months original mandate.

Honduras: Honduras established the Truth and Reconciliation Commission for eight months on May 4, 2010. It investigated the grave human rights violations that occurred during the military coup in June 2009 on the course to ousted the then President Manuel Zelaya (United States Institute of Peace, February 9, 2012). The Commission was created based on the Accord for National Reconciliation and the Strengthening of Democracy in Honduras (Friendship Office of the Americas, November 1, 2009). However, the new President Porfirio Lobo Sosa, signed a general amnesty law for crimes related to the coup before the Commission completed its work (United States Institute of Peace, February 9, 2012). The Commission report failed to recommend prosecution to those responsible for the violations during the coup (Allison \& Reid, March 2015). Against the TRC, civil society including human rights platform of Honduras launched an alternative Truth Commission on June 28, 2010 headed by famous human rights defender and Nobel Peace Prize winner Adolfo Perez Esquivel (Center for Constitutional Rights, Undated).

Besides, the Committee of the Relatives of Disappeared in Honduras investigated 184 cases of enforced disappeared persons that occurred in 1981 (Amnesty International, 1998). The Honduras civilian Government was elected in 1981, but human rights violations continued due to strong military tie with the America's CIA, US military bases (Cohn \& Ginger, June 11, 1995) and Chile, during the presidency of the dictator Augusto Pinochet. The Panama report concluded that the military regime was responsible for human rights violations or abuses of the victims during its dictatorship (1968-1972). A total of 110 of the 148 cases were documented (United States Institute of Peace, January 1, 2001). The commission recommended conducting systematic excavations at 40 cases of suspected graves and advised the Office of Special Prosecutor to take legal action against those suspected of committing those atrocities (Amnesty International, 1998).

Mexico: The Mexican Government set up the Commission for Truth and Access to Justice in the Ayotzinapa Case on January 15, 2019 where 43 young students were enforcedly disappeared on September 26, 2014 (teleSUR, January 16, 2019). Ministry of the Interior official stated that the Commission shall investigate the disappearance of more than 37,000 Mexicans in the past (teleSUR, January 16, 2019). The case of the kidnapped students revealed that there was a culture of close cooperation between the local political establishment and criminal gangs (International Commission on Missing Persons, Undated).

Nicaragua: The National Assembly of Nicaragua appointed, ratified and swore in members of the Commission for Truth, Justice and Peace on May 6, 2018 (ICTJ, May 10, 2018) for three months. The Commission investigated, analyzed and clarified the truth of the massacre perpetrated by the Police and groups related to the Sandinista Front, against unarmed students 
while they were protesting against reforms to the social security system (BBC, May 7, 2018 \& Confidential, May 7, 2018). On January 24, 2019, the Government approved the Law for a Culture of Dialogue, Reconciliation, Security, Labor and Peace in Nicaragua on the course to formulate the Truth Commission (Inter-American Commission on Human Rights, February 2, 2019). The report stated that of the total 253 deaths, 220 were directly related to the conflict, 27 were from crossfire, and 6 were indirectly related to the conflict (Sefton, Feb 12, 2019).

Panama: The Panama Commission studied human rights violations or abuses perpetrated during the military dictatorship (1968-1989) (United States Institute of Peace, January 1, 2001). The report illustrated that the military regime was involved in torture and cruel, inhuman and degrading treatment. The report stated that out of 110 cases examined, 40 were disappeared and 70 were known to be murdered. The report recommended further for exhumation and investigation (United States Institute of Peace, January 1, 2001).

Paraguay: The Paraguayan Truth and Justice Commission collected 2,059 testimonies, 14,000 documents and conducted eight public hearings from the complaints of 19,862 arbitrary detentions, 18,772 cases of torture, 59 victims of summary executions, 336 forced disappearances and a total of more than 128,000 victims of the military regime (United States Institute of Peace, June 1, 2004). It recommended continuing the search for the enforced disappeared persons, establishing public genetics database, and including the report in the curriculum of public schools. The Commission suspended its investigations as the government stopped funding in December 2007 (Bobowik, Arnoso \& Beristain, January 2015).

Peru: The Truth and Reconciliation Commission in Peru investigated human rights violations including extrajudicial killings and disappearances committed by the State, the Shining Path and the Túpac Amaru Revolutionary Movement (May 1980-November 2000) (United States Institute of Peace, July 13, 2001). The Commission documented 69,280 cases of extrajudicial killings including disappearances along with 4,600 burial sites where the Shining Path was responsible for 54 percent and State security forces notably Alberto Fujimori were responsible for 44.5 percent. A great majority of the victims were poor indigenous peasants who had been socio-economically marginalized for generations (United States Institute of Peace, July 13, 2001). The Constitutional Tribunal in 2004 confirmed the right to know the truth (Cueva, 2004) and whereabouts of the disappearance cases. The report recommended calling for integrated reparations and national reconciliation (Toledo, July 20, 2009). The Shining Path's leaders and cadres were sentenced based on the civil-anti-terrorism court's verdicts (Theidon \& Laplante, 2007). Former President Alberto Fujimori was convicted for 25 years (AFP-JiJi, December 22, 2016). He was pardoned on December 24, 2017 in the name of humanitarian treatment (BBC, December 25, 2017), but four years old rebel leader Abimael Guzman is still in jail. A total of 2,891 bodies have been exhumed, but only 53 percent $(1,525)$ remains have been given back to their families (Peru's Painful Mirror, Undated).

Uruguay: The Uruguay Commission I (Commission for the Investigation of the Situation of the Disappeared and Related Events) identified the enforced disappeared persons during the military rule (1973-1985) (Stern \& Daniel, 2010). The Commission for Peace as the Uruguay Commission II was formed to investigate the fates and whereabouts of the estimated 200 disappearances that had happened (1973-1985). It means, two Commissions in Uruguay were formed on two different occasions to work on the same issue of enforced disappearances (EAAF, 2002).

The Uruguayan Commission I documented 164 cases of disappearances. Because of the repressive actions of the Uruguayan armed forces and political pressures, the final report was changed and never announced publicly. It was granted a limited mandate to investigate the 
enforced disappeared persons (Hayner, 2011). After 11 years of military rule, the Commission was formed by the Uruguayan Parliament. The report of Uruguayan Commission II handed over to the Supreme Court identified 38 disappeared persons comprising 32 Uruguayan and 6 Argentinean. The State security forces were responsible in most of the cases of disappearance (United States Institute of Peace. August 1, 2000). The Commission's authority was limited that allowed statements from those who voluntarily agreed to make a testimony submission (Allier, October 2006). In 2006, former President Juan Maria was arrested on the charge of killings. Uruguayan Court approved him and his foreign minister's trial for 30 years in 2010 (Hayner, 2011). The 14 Generals of the Army and the Commander-in-Chief publicly stated that the report was biased (United States Institute of Peace, August 1, 2000).

\section{iii. European Truth Commissions}

Balkans: Balkans established the "Regional Commission Tasked with Establishing the Facts about All Victims of War Crimes and Other Serious Human Rights Violations" (RECOM) in October 28, 2008 in Pristina, Kosovo to investigate human rights violations committed on the territory of the former Yugoslavia that had happened during January 1, 1991 to December 31, 2001 (RECOM, Undated). Former Yugoslavia dissolved into Bosnia-Herzegovina, Croatia, Kosovo, Macedonia, Montenegro, Serbia and Slovenia. RECOM is an Extra-judicial Intergovernmental Body which was established to investigate all war crimes, crimes against humanity and genocide collecting statements and testimonies from the victims and organizing public hearings (RECOM). However, the Balkan Transitional Justice Commission will be constituted by 2021 and will start its work on April 16, 2022 (Rudic, May 23, 2018).

Germany: Germany launched the Commission I for the East German Communist Government (949-1989) on the course to document human rights violations or abuses. It assessed the historical, ideological, politico-economical and societal features of the dictatorship including the misuse of environmental resources (Human Rights Watch, April 1995) whereas the Germany Commission II investigated the practices of the East German Government's 19491989 regimes (United States Institute of Peace, July 1, 1995).

The German victims severely criticized the communist regimes owing to injustice to them (Forsythe, 2009). It resulted in the establishment of the Commission I of Inquiry on Overcoming the Consequences of the SED Dictatorship in the Process of German Unity. The report was prepared based on the testimonies of witnesses, theoretical and political assessments of the dictatorship (United States Institute of Peace, May 1992). It recommended the use of national holidays, memorials, and documentation centers. The recommendations have become exemplary to the neighboring States in Europe (United States Institute of Peace, May 1992). The Commission II in Germany produced the report in 14 volumes focusing on economic, social, environmental, education, science, culture and daily life policies in East Germany. The reports covered everyday aspects of repression, the blanket discrimination against women and severe restrictions and violent atrocities (United States Institute of Peace, July 1995). They suggested ensuring reparation for former political prisoners and other victims (McAdams, April 2001).

Yugoslavia (Serbia and Montenegro): Former Yugoslavia formed a Truth and Reconciliation Commission for finding out the social, inter-communal and political conflicts that occurred during 1980-2000. The Commission documented to establish cooperation in neighboring countries' Commissions (Zupan, 2006). The Commission of former Yugoslavia was created and outlined its mandate in March 2001, but the office was inaugurated in February 2002 only. In February 2003, Yugoslavia was formally dissolved and transformed into Serbia and Montenegro (United States Institute of Peace, February 1, 2002). Moreover, the Commission got disbanded while the Office of the President of Yugoslavia no longer existed. The new 
government denied continuing or reinstating the Commission. Previously, the Commission had a plan to fully cooperate with International Criminal Tribunal for Former Yugoslavia (United Nations International Criminal Tribunal for the former Yugoslavia, October 19, 2017) where Former President Slobodan Milosevic was taken into custody in The Hague on the charges of war crimes, crimes against humanity and genocide (Freeman, October 2004). No report was produced as the Commission never registered complaints from the victims, never conducted interviews and public hearings (Ilic, April 23, 2004). The Commission was much criticized both inland and abroad (Hayner, 2011).

\section{iv. Asia-Pacific Truth Commissions}

Bangladesh: Bangladesh military-backed Caretaker Government set up a Truth and Accountability Commission (TAC) on July 30, 2008 that would allow the corrupt politicians and businessmen not to be sent to jail if they confessed and refunded money obtained illegally. The Truth Commission was headed by a former high court justice and members were a retired army general and an ex-chief government auditor (Business Recorder, July 31, 2008). Formation of the TAC was declared illegal by the High Court on December 15, 2008 under the Bangladesh Constitution (Library of Congress, December 15, 2008). The Supreme Court also declared the TAC illegal which had set up to offer amnesty to the responsible ones and partial amnesties in return for information about corruption (Ethirajan, May 16, 2011). However, a domestic war crimes tribunal in Bangladesh was also set up in 2009 to investigate and prosecute perpetrators for the genocide committed in 1971 by the Pakistan Army and their Bangladeshi collaborators (Wierda \& Triolo, May 31, 2012; Samad, April 29, 2016).

Cambodia: The Extraordinary Chambers in the Courts of Cambodia (ECCC) was established in 2006 to investigate war crimes and crimes against humanity during the past wrongdoings (April 1975 to January 1979) in the Pol-Pot's regimes (A/RES/57/228, March 22, 2003; Dicklitch \& Malik, 2010, January 9). It was a Special Cambodian Hybrid Court, comprising both national and international judges, that received United Nations' Assistance to the Khmer Rouge Tribunal (Khmer Rouge Trial or Cambodia Tribunal) (Introduction to the ECCC, Undated, ECCC at a Glance, April, 2014; Ainley, 2014). After 12 years of operation (for the very first time), the ECCC convicted two senior-most leaders (such as Deputy Nuon Chea, 92 and Head of State Khieu Samphan, 87 of Pol Pot's Khmer Rouge regime) for life imprisonment, on charges of exterminating Cham Muslim and ethnic Vietnamese communities on November 18, 2018 (Case File No. 002/19-09-2007/ECCC/TC, November 18, 2018).

East-Timor: The Commission for Reception, Truth and Reconciliation in East-Timor conducted 8 national hearings with 1,048 research interviews and collected 7,760 complaints or individual statements from the victims (United States Institute of Peace, February, 2007). A total of 102,800 Timorese were either killed or died from conflict induced starvation and illness owing to Indonesian occupation. Indonesian Minister of Defense, chiefs of military and police were named as principal perpetrators (CAVR Chega! Report, 2015). It recommended setting up reparations for victims and conducting further investigation of mass graves to identify the fates and whereabouts of the disappeared persons. It recommended that those involved in less-serious crimes would apologize, but would agree either to undertake community service or make symbolic reparatory payments or public apology (International Center for Transitional Justice, February 23, 2016). The crimes against humanity committed by the Indonesian authorities have not been addressed yet as they did not show any interest to implement the Commission's report (International Center for Transitional Justice, February 23, 2016). The UN led crimes unit issued a warrant to arrest Indonesian army general Wiranto, but the Timorese leadership objected to it. Thus, the UN left the prosecution part to the Timorese Attorney General (Hayner, 2011). 
Nepal: The enforced disappearance cases of Nepal Commission I were investigated to identify the fates and whereabouts of those ensued during the autocratic Panchayat regime (19501990) (United States Institute of Peace, January 1, 1990). The Commission I report documented 35 cases of enforced disappeared persons of which 5 of them were extra-judicially killed (Pathak, May 18, 2015). The perpetrators were neither identified nor any reparation was provided to those affected victims or their families. The report was made public in 1994 as a result of massive pressure from the public. Nepal Commission II of Investigation on Enforce Disappeared Persons (CIEDP) was established in February 2015 to investigate the cases of human rights violations and/or abuses during the People's War (1996-2006). It has already completed collecting the statements from the victims or complainants and witnesses and other required testimonies and evidence from the concerned survivors and society at large from 64 districts (out of 75) in four years period. However, the ruling Government comprising the perpetrators terminated the tenure of the Commissioners including the Chair in April 2019 fearing whether the statements, testimonies or documentation of each and every individual disappeared persons would provide evidence to prosecute and punish the perpetrators. Thus, the CIEDP mostly handled the cases of disappearance of the decade long armed insurgency (Pathak, December 15, 2008). However, another twin-Truth and Reconciliation Commission did not complete an investigation even of a single district during the four-year same period owing to tug-of-war among politically indoctrinated Commissioners.

Philippines: The Transitional Justice and Reconciliation Commission in the Philippines was established in 2014 to investigate the complaint cases of the Enforced Disappearances (ED), extrajudicial killings, massacres, tortures and other forms of human rights violations that had taken place since 1972 (Executive Order No. 8, March 18, 1986). In the Philippines, Aquino's trusted Chairman José Diokno drafted the specific mandate that limited its investigation jurisdiction of what had violated the civilian rights by the army or its agents in the past, but insurgents' crimes could directly be dealt by the courts. On the one hand, the army put hurdles on the Commission's work (Transitional Justice and Reconciliation Commission, July 6, 2016). The Commission submitted its report on March 2016.

South Korea: South Korea formed two Truth Commissions. The Commission I stressed upon looking into the death of citizens in South Korea (1975-1987) and the report, which identified the perpetrators for prosecution, was submitted to the President. The victims filed complaints requesting for investigation (Sang-bun, April 2004). The Commission II investigated the incidents of Korean history (1910-1993) that occurred from Japan's occupation over Korea and ended the authoritarian rule after the election of President Kim Young-sam in 1993 (Truth and Reconciliation Commission, March 20, 2009). Commission I concluded that the dictatorial regimes had been responsible for 52 cases of victims' families. It recommended legal actions against the confirmed perpetrators (United States Institute of Peace, October 1, 2000). Likewise, Commission II estimated that tens of thousands of people were extrajudicially killed in the summer of 1950. The victims included a wide range such as political prisoners, civilians killed by the US forces and civilians who were allegedly collaborating with the communist North Korea or local communist parties (Sang-Hun, December 3, 2007). The Commission recommended a number of cases for formal prosecutions (Gunson, August 17, 2006). Among 1,200 petitioners to reparations, only 400 victims received payments (US Department of State, 2007; Truth and Reconciliation Commission, 2005).

Sri Lanka: Sri Lanka formed an enforced disappeared persons' commission to investigate the whereabouts of the missing persons (January 1,1988-December 1994) (United States Institute of Peace, January 1, 1995). Sri Lanka documented 27,000 complaints and investigated over 15,000 cases of enforced disappearances. In the lack of time, 10,136 complaints were 
transmitted to All Islands Commission which further collected 16,305 disappeared persons. However, All Islands Commission investigated 2,127 cases only. Remaining cases were transferred to the Sri Lankan National Human Rights Commission (NHRC). The NHRC denied conducting further investigation unless they received special directions from the Government (United States Institute of Peace, January 1, 1995). All four reports stated that excessive powers were used during the violence on anti-government struggles. They recommended compensation and rehabilitation for the victims and survivors. Accordingly, compensation was paid to some of the families of the victims (Nesiah \& Keenan, 2004). The Commission II, the administrative Office of the Missing Persons (OMP) was opened on May 22, 2016 (Dibbert, September 19, 2017); however, it received a seven-member team of the OMP on February 28, 2018 which also comprised the retired Major General (Nain, March 24, 2018; Lassee, 2017). It is mandated to investigate families whose loved ones had disappeared, from the 1980s to 2016.

The Generation-II does not reflect the age group alone, but also focuses on the trends and patterns of the justice system. This Generation-II changes a notion of internecine war to ensure truth, justice, reparation, vetting, prosecution and institution reform to the victims, survivors and society at a large and perpetrators (Pathak, forthcoming) putting the core values of human rights, international criminal law and international humanitarian law at the center of investigation establishing the transitional justice body, named Truth Commission.

Over dozen countries (viz. Burundi, Central African Republic, Colombia, Ecuador, El Salvador, Germany, Mali, Nepal, Philippines, South Korea, Sri Lanka, Uganda and Uruguay) have established more than one Truth Commission. Nepal has established two Commissions: the Commission of Investigation on Enforced Disappeared Persons (CIEDP) and the Truth and Reconciliation Commission (TRC) at a time by a single Act 2014. The twin-commission (i.e. CIEDP and TRC) shall be the first case in the world. The CIEDP of Nepal has already given a model of investigation.

The United Nations had been involved in seven countries' TJ process: El Salvador, Guatemala, East-Timor, Sierra Leone, Liberia, Solomon Islands, and Eritrea. The UN established its Commissions in Sierra Leon, El Salvador and East-Timor, but failed to restore normalcy in Kosovo. The Liberian truth commission threatened the government to submit its findings to the International Criminal Court. Most Truth Commissions are Court-like bodies, but without binding authority, except in Sierra Leone. The TRCs of Argentina, East-Timor, Guatemala, Morocco, Peru and South Africa partially succeeded. A few Commissions such as in Bolivia, Ecuador, Haiti, former Yugoslavia and Zimbabwe were disbanded (without their reports) before their tenures expired.

No public hearings were conducted in Argentina and former Yugoslavia, but only 8 public hearings in Ghana, 8 national hearings in East-Timor and 15 in Brazil. Moroccan Commission held public hearings after signing the bond paper for not disclosing the names of the perpetrators whereas Guatemala did not include the perpetrators' names in the report. Haiti prosecuted 50 perpetrators whereas Guatemala prosecuted its former military dictator. The Philippines' Commission had limited investigation jurisdiction over the army.

\section{GENERATION-III: A NOTION CHANGED FROM DOMESTIC CRIMINAL JURISPRUDENCE TO INTERNATIONAL TRIBUNAL JUSTICE}

The Nuremberg Trials initiated a great movement for the promotion and establishment of justice by the International Court, eventually leading over fifty years later. The ICC has the power to exercise its jurisdiction over the person(s) for the most serious crimes of 
international concern and shall be complementary to national criminal jurisdictions (Triffterer, October 27, 2015). The Court could prosecute the perpetrators of the most heinous crimes committed in their territories to their nationals after the Rome Statute entry into force (United Nations, 2002).

The United Nations General Assembly convened a conference in Rome in June 1998. The Conference adopted the Rome Statute of the International Criminal Court on July 17, 1998 which has been adopted by 123 States (United Nations: Treaty Collection, Undated), but seven countries namely China, Iraq, Israel, Libya, Qatar, United States of America and Yemen voted against the treaty (Scharf, August11, 1998). Moreover, the Rome Statute has itself been a historic milestone in humankind's efforts towards a development of peaceful, prosperous and harmonious world. Following 60 countries' ratifications, the ICC was formally established on July 1, 2002 (Arsanjani, January 1999). The ICC deals with the crimes committed after this date, without retroactive jurisdiction. The Government of Uganda has been the first country to Situation referred to the ICC in January 2004 (https://www.icc-cpi.int/uganda).

The International Criminal Court is a permanent Court that puts on trial to suspect individuals on international crimes of genocide ${ }^{\mathrm{i}}$, crimes against humanityii and war crimesii (International Criminal Court, Undated) and the second amendment included the crimes of aggression ${ }^{\text {iv }}$ in 2010. The principal objective of the Court is to investigate, prosecute and try individuals accused of committing the most serious crimes to international community as a whole (U.N. Doc. A/CONF.183/9, July 1, 2002). The ICCv has four main aims: to ensure the worst perpetrators to be held accountable for crimes; to serve as a Court of last resort that can investigate, prosecute and punish the perpetrators of crimes; to assist national judiciaries in the investigation and prosecution of perpetrators (to allow State to be the first to investigate and prosecute); and to help promote peace and security be deterring potential perpetrators (International Criminal Court, Undated).

The ICC conducts a total of 20 countries comprising of 11 situations under investigations in 10 countries and 10 countries under preliminary examinations till the end of 2018. Situations under investigations countries are: DR Congo (June 23, 2004-), Uganda (July 29, 2004-), Darfur, Sudan (June 6, 2005-), Central African Republic I and II (May 22, 2007-), Kenya (March 31, 2010-), Ivory Coast (February 10, 2011-), Libya (February 26, 2011-), Mali (January 16, 2013-), Georgia (January 27, 2016-) and Burundi (October 25, 2017-).

Democratic Republic of Congo (DRC): It becomes independent from Belgium and Joseph Mobutu (Mobutu Sese Seko) led the country. In four months (i.e. April to July) in 1994, it was estimated that 800,000 including great majority Tutsis and some Hutus were killed in the Rwandan genocide (http://www.unhcr.org/en-my/3ebf9bb60.pdf). The armed conflict flooded millions of Hutus refugees including 1.2 million in the Ituri and Kivu provinces in DRC, 580,000 in Tanzania, 270,000 in Burundi and 10,000 in Uganda (UNHCR, November 16, 1994).

In 1996, the joint forces of the Rwanda and Uganda invaded the eastern DRC to root out the Hutus in the name of the genocide perpetrators which defeated military dictator Mobutu Sese Seko, long-term ruling regime (1965-1997). The UN High Commissioner for Refugees estimated that only 7 percent of these refugees were perpetrators (Eastern Congo Initiative, Undated). Laurent Desire Kabila became the new President with support from the Rwanda and Uganda forces, but President Kabila ordered to leave the forces from eastern DRC with support from Angola, Namibia and Zimbabwe. At the same time, when Kabila was assassinated by his bodyguard in 2001, his son Joseph Kabila succeeded his father at the age of 29. President Kabila succeeded to sign the Pretoria Accord (Rwanda) and Luanda Agreement (Uganda) 
which formally ended the conflict withdrawing their forces in 2003 (BBC, August 1, 2018). President Kabila signed a Transitional Constitution to investigate the cases of human rights violations and international humanitarian law and to rule the Interim Government (BBC, August 1, 2018).

As the power-sharing peace deal with Uganda concluded in April 2002, the DRC ratified the Rome Statute. In April 2004, the DRC Government referred the situations to the ICC to investigate and prosecute war crimes and crimes against humanity committed after July 1 , 2002. It aimed to bring the perpetrators in accountability action and effective national and regional justice strategies. These strategies included rebuilding the national justice system on the course to address all of the crimes committed in the country and to ensure reparations for victims to rebuild their lives (https://www.icc-cpi.int/drc). The ICC opened its investigation in June 2004 (ICC-PIDS-TCT-01-090/18_Eng). The prosecutor opened an investigation of six suspects: Thomas Lubanga Dyilo, Germain Katanga, Mathieu Ngudjolo Chui, Bosco Ntaganda, Callixte Mbarushimana and Sylvestre Mudacumura.

Thomas Lubanga was a founder and rebel military commander of the Union of Congolese Patriots. He was charged with war crimes enlisting children, conscription of children and using children to participate in hostilities from July 2002 to December 2003 in the Ituri region. On February 10, 2006, Pre-Trial Chamber issued a warrant of arrest to Lubanga and Congo Government transferred Lubanga to the Court's custody in The Hague on March 17, 2006. He first appeared before Court on March 20, 2006 and was informed of the crimes to have allegedly been committed. On January 29, 2007, the judges of the Pre-Trial Chamber confirmed the charges against him. On July 10, 2012, Trial Chamber delivered a final verdict of sentencing him for a total period of 14 years of imprisonment, but the said period that he spent in the Court custody shall be deducted. He has already completed his tenure of detention. On December 19, 2015, Lubanga was transferred to a prison in DR Congo to serve his other sentences of imprisonment (ICC-PIDS-CIS-DRC-01-016/17_Eng). On December 15, 2017, Trial Chamber set the amount of his liability for collective reparations at USD 10,000,000 (ICC-PIDSTCT-01-090/18_Eng).

A warrant of arrest to another rebel leader Germain Katanga was issued on July 2, 2007. While Katanga was charged with crimes against humanity, he was transferred to the detention center at The Hague from Congo on October 17, 2007. On September 26, 2008, the Pre-trial Chamber confirmed the war crimes and crimes against humanity against him (ICC-PIDS-CIS-DRC-03014/18_Eng). On March 7, 2014, Trial Chamber found him guilty of crime against humanity committed on February 24, 2003 during an attack on the village of Bogoro, in Ituri, but he was acquitted of the other charges that he had been facing (ICC, March 7, 2014). On May 23, 2014, Trial Chamber sentenced him to a total of 12 years' imprisonment that deducted the time spent in ICC detention. On December 19, 2015, he was transferred to a DRC prison to serve his other sentences. However, his sentence completed on January 18, 2016 reducing the original sentence to 8 years 4 months. On March 24, 2017, Trial Chamber directed to award individual and collective reparations to the victims and the Appeals Chamber confirmed the Reparations Order on March 8, 2018 (ICC-PIDS-TCT-01-090/18_Eng).

Despite Army's Colonel Mathieu Ngudjolo Chui's alleged involvement in war crimes enlisting children under the age of 15 to take active part in the warfare; willful killing; sexual slavery; and destruction of property and crimes against humanity (murder, rape and sexual slavery) committed in February 2003 in Ituri, former colonel of the Congolese Army Chui was acquitted on December 18, 2012 (Escritt, December 18, 2018) and released three days later. Similarly, the Pre-Trial Chamber declined to confirm the charges against Callixte Mbarushimana on war 
crimes and crimes against humanity. And the appeal of prosecution against him was dismissed (BBC News, December 16, 2011). He was released from the ICC custody on December 23, 2011.

The ICRC issued a warrant of arrest against Bosco Ntaganda the first time on August 22, 2006 and the second time on July 12, 2012 (ICC-PIDS-TCT-01-090/18_Eng). On March 18, 2013, he voluntarily surrendered into the U.S. Embassy in Rwanda and asked them to transfer him at the ICC. And, ICC took him in its detention center on March 22 (ICC-PIDS-CIS-DRC-02011/15_Eng). Ntaganda's trial opened on September 2, 2015 (ICC-PIDS-CIS-DRC-02011/15_Eng). His charges were confirmed and he is in ICC custody (ICC-CPI-20180704MA228). He faces 30 years in jail for alleged war crimes committed in DRC (Maclean, August 30, 2018). Similarly, Sylvestre Mudacumura was also charged with war crimes including attacking civilians, mutilation, murder, rape, torture, destruction of property and among others allegedly committed from January 20, 2009 to the end of September 2010 in the Kivus. His case is in pre-trial state owing to his absence 'fugitive' in the Court (ICC-PIDS-CIS-DRC-05006/18_Eng).

\begin{tabular}{|c|c|c|c|c|c|c|}
\hline$\#$ & $\begin{array}{c}\text { Name of Inductee } \\
\text { or Suspect }\end{array}$ & $\begin{array}{c}\text { Situation } \\
\text { in }\end{array}$ & Profession & Charge & $\begin{array}{c}\text { Date of } \\
\text { Indictment }\end{array}$ & Current Status \\
\hline 1 & Thomas Lubanga & DR Congo & $\begin{array}{l}\text { Rebel } \\
\text { Commander }\end{array}$ & $\begin{array}{l}\text { War crimes- } \\
\text { conscription to } \\
\text { child soldier }\end{array}$ & $\begin{array}{l}\text { Arrest } \\
\text { warrant } \\
\text { issued on Feb. } \\
10,2006\end{array}$ & $\begin{array}{l}\text { Completed } 14 \text { years' } \\
\text { sentence imprisonment, } \\
\text { but transferred to DRC } \\
\text { prison. Collective } \\
\text { reparations to be paid. }\end{array}$ \\
\hline 2 & Germain Katanga & DR Congo & Rebel Leader & $\begin{array}{l}\text { War crimes and } \\
\text { crimes against } \\
\text { humanity }\end{array}$ & $\begin{array}{l}\text { Arrest } \\
\text { warrant } \\
\text { issued on July } \\
2,2007\end{array}$ & $\begin{array}{l}\text { Completed } 12 \text { years' } \\
\text { sentence imprisonment, } \\
\text { but transferred to DRC. } \\
\text { Reparations to be paid. }\end{array}$ \\
\hline 3 & Ahmad Al Mahdi & Mali & $\begin{array}{l}\text { Rebel Leader } \\
\text { (associated to } \\
\text { Al Qaeda) }\end{array}$ & $\begin{array}{l}\text { War crimes- } \\
\text { attacks against } \\
\text { religion }\end{array}$ & $\begin{array}{l}\text { Arrest } \\
\text { warrant } \\
\text { issued on Sep. } \\
18,2015\end{array}$ & $\begin{array}{l}\text { Sentenced to nine years' } \\
\text { imprisonment. Collective } \\
\text { reparations to be paid. }\end{array}$ \\
\hline
\end{tabular}

Darfur, Sudan: From March 2003 to July 2008, non-international character a protracted armed conflict existed in Darfur between the Government security forces and the armed insurgents. The United Nations estimated that there were 1.65 million internally displaced persons in Darfur, and more than 200,000 refugees fled to neighboring Chad and large-scale of the destruction of villages happened throughout the three States of Darfur (S/2005/60). It was estimated that 300,000 people were extrajudicially killed during the conflict (BBC, March 4, 2009).

While Sudan had not been a State Party to the Rome Statute, Darfur situation was referred to the ICC by the UN Security Council first of its kind under its VII Chapter of the International Peace and Security Charter on March 31, 2005. The UNSC referred the situation of Darfur with the Resolution 1593 over alleged genocide, war crimes and crimes against humanity (International Criminal Court, June 8, 2017) committed in Darfur, Sudan since July 1, 2002. The UN Security Council established a Court for investigation in June 2005 following the recommendation of the report of the International Commission of Inquiry on violations of international humanitarian law and human rights law in Darfur (S/2005/60). The UN Resolution was passed by a vote of 11 (Argentina, Benin, Denmark, France, Greece, Japan, the Philippines, Romania, Russia, Tanzania, and the UK) in favor with none against, but four (Algeria, Brazil, China, and USA) were absent (SC/8351, March 31, 2005). 
The Objective of the ICC was to investigate the violations of international humanitarian law and human rights law in Darfur committed by all parties; to determine whether or not acts of genocide, crimes against humanity and war crimes have occurred; and to identify the perpetrators involved on such violations with a view to ensuring that those responsible are held accountable (Elagab, September 2008).

On May 2, 2007, the Pre-Trial Chamber of the Court issued (the first warrant of arrest on the charge of war crimes and crimes against humanity) against Minister Ahmad Muhammad Harun and Government sponsored Janjaweed militia leader Ali Kushayb (UN News, May 2, 2007). But, they remained at large or fugitives (ICC-PIDS-CIS-SUD-001-005/18_Eng).

\begin{tabular}{|c|c|c|c|c|c|c|}
\hline$\#$ & $\begin{array}{c}\text { Name of Inductee } \\
\text { or Suspect }\end{array}$ & $\begin{array}{c}\text { Situation } \\
\text { in }\end{array}$ & Profession & Charge & $\begin{array}{c}\text { Date of } \\
\text { Indictment }\end{array}$ & Current Status \\
\hline 1 & Raska Lukwiya & \multirow[t]{2}{*}{ Uganda } & $\begin{array}{l}\text { Rebel } \\
\text { Commander }\end{array}$ & \multirow{2}{*}{$\begin{array}{l}\text { War crimes, } \\
\text { crimes against } \\
\text { humanity and } \\
\text { enslavement }\end{array}$} & \multirow{2}{*}{$\begin{array}{l}\text { Arrest } \\
\text { warrant } \\
\text { issued on July } \\
8,2005\end{array}$} & $\begin{array}{l}\text { Proceedings dismissed due } \\
\text { to forensic confirmation of } \\
\text { his death- killed by State } \\
\text { forces. }\end{array}$ \\
\hline 2 & Okot Odhiambo & & Rebel Leader & & & $\begin{array}{l}\text { Proceedings dismissed due } \\
\text { to forensic confirmation of } \\
\text { his death. }\end{array}$ \\
\hline 3 & Saleh Jerbo & $\begin{array}{l}\text { Darfur } \\
\text { (Sudan) }\end{array}$ & $\begin{array}{l}\text { Rebel } \\
\text { Commander }\end{array}$ & $\begin{array}{l}\text { War crimes } \\
\text { attacked to AU } \\
\text { Peacekeepers }\end{array}$ & $\begin{array}{l}\text { Summons } \\
\text { issued on } \\
\text { Aug. 27, } 2009\end{array}$ & $\begin{array}{l}\text { Proceedings dismissed as he } \\
\text { was killed by its rebel- } \\
\text { splinter group. }\end{array}$ \\
\hline 4 & Muammar Gaddafi & Libya & President & $\begin{array}{l}\text { Crimes against } \\
\text { humanity }\end{array}$ & $\begin{array}{l}\text { Arrest } \\
\text { warrant } \\
\text { issued on } \\
\text { June 27, } 2011\end{array}$ & $\begin{array}{l}\text { Proceedings dismissed as he } \\
\text { was inhumanly killed by the } \\
\text { agitators. }\end{array}$ \\
\hline 5 & $\begin{array}{l}\text { Callixte } \\
\text { Mbarushimana }\end{array}$ & \multirow{3}{*}{ DR Congo } & $\begin{array}{l}\text { Rebel Leader } \\
\text { (Hutu) }\end{array}$ & $\begin{array}{l}\text { Crimes against } \\
\text { humanity and } \\
\text { war crimes }\end{array}$ & $\begin{array}{l}\text { Arrest } \\
\text { warrant } \\
\text { issued on Sep. } \\
28,2010\end{array}$ & $\begin{array}{l}\text { Pre-Trial Chamber } \\
\text { dismissed the charges and } \\
\text { released from the ICC } \\
\text { custody. }\end{array}$ \\
\hline 6 & $\begin{array}{l}\text { Mathieu Ngudjolo } \\
\text { Chui }\end{array}$ & & $\begin{array}{l}\text { Colonel of } \\
\text { Congolese } \\
\text { Army }\end{array}$ & $\begin{array}{l}\text { War crimes and } \\
\text { crimes against } \\
\text { humanity }\end{array}$ & $\begin{array}{l}\text { Arrest } \\
\text { warrant } \\
\text { issued on July } \\
6,2007\end{array}$ & $\begin{array}{l}\text { Dismissed and released } \\
\text { from ICC custody on } \\
\text { December } 21,2012 .\end{array}$ \\
\hline 7 & Jean-Pierre Bemba & & $\begin{array}{l}\text { Former Vice } \\
\text { President }\end{array}$ & $\begin{array}{l}\text { Crimes against } \\
\text { humanity and } \\
\text { sexual violence }\end{array}$ & $\begin{array}{l}\text { Arrest } \\
\text { warrant } \\
\text { issued on } \\
\text { June } 10,2008\end{array}$ & $\begin{array}{l}\text { The Court granted interim } \\
\text { release, but sentenced to } 18 \\
\text { years. Appeal Chamber } \\
\text { overturned his charges. }\end{array}$ \\
\hline 8 & Francis Muthaura & \multirow{6}{*}{ Kenya } & $\begin{array}{l}\text { Head of Civil } \\
\text { Service }\end{array}$ & \multirow{2}{*}{$\begin{array}{l}\text { Crimes against } \\
\text { humanity }\end{array}$} & \multirow{2}{*}{$\begin{array}{l}\text { Summons } \\
\text { issued on } \\
\text { March 8, } \\
2011\end{array}$} & \multirow{2}{*}{$\begin{array}{l}\text { The Prosecutor withdrew } \\
\text { charges. Proceedings of } \\
\text { their cases terminated } \\
\text { (dismissed). }\end{array}$} \\
\hline 9 & Uhuru Kenyatta & & President & & & \\
\hline 10 & William Ruto & & $\begin{array}{l}\text { Deputy } \\
\text { President }\end{array}$ & \multirow{4}{*}{$\begin{array}{l}\text { Crimes against } \\
\text { humanity }\end{array}$} & \multirow{4}{*}{$\begin{array}{l}\text { Summons } \\
\text { issued on } \\
\text { March 8, } \\
2011\end{array}$} & \multirow{4}{*}{$\begin{array}{l}\text { Trial Chambers dismissed } \\
\text { their charges in the lack of } \\
\text { evidences and testimonies. }\end{array}$} \\
\hline 11 & Joshua Sang & & $\begin{array}{l}\text { Operation } \\
\text { Head }\end{array}$ & & & \\
\hline 12 & Henry Kosgey & & Minister & & & \\
\hline 13 & $\begin{array}{l}\text { Mohammed Hussein } \\
\text { Ali }\end{array}$ & & $\begin{array}{l}\text { Army } \\
\text { Commander }\end{array}$ & & & \\
\hline 14 & Bahr Abu Garda & Darfur & Rebel Leader & War crimes & $\begin{array}{l}\text { Summons } \\
\text { issued on May } \\
7,2009\end{array}$ & $\begin{array}{l}\text { He voluntarily appeared } \\
\text { before Court issuing } \\
\text { warrant of arrest. Charges } \\
\text { dismissed. }\end{array}$ \\
\hline 15 & Abdullah Al-Senussi & Libya & $\begin{array}{l}\text { Former } \\
\text { Intelligence } \\
\text { Chief }\end{array}$ & $\begin{array}{l}\text { War crimes and } \\
\text { crimes against } \\
\text { humanity }\end{array}$ & $\begin{array}{l}\text { Arrest } \\
\text { warrant } \\
\text { issued on } \\
\text { June } 27,2011\end{array}$ & $\begin{array}{l}\text { Sentenced to death by the } \\
\text { Libyan Court. His charges at } \\
\text { the ICC declared (dismissed) } \\
\text { inadmissible to continue. }\end{array}$ \\
\hline
\end{tabular}

Note: Table 2 is a summary of the Court's dismissal of charges, extracted from information and analysis of Generation III 
On March 4, 2009, the Pre-Trial Chamber issued a warrant of arrest-I to another sitting StateHead President Omar Al Bashir for war crimes and crimes against humanity for the first time and arrest-II on July 12, 2010 on the charge of genocide (www.icc-cpi.int/darfur/albashir). He remains at large, 'fugitive' (ICC-PIDS-CIS-SUD-001-005/18_Eng). The ICC issued a warrant of arrest to the former Defense and Interior Minister and present Governor of Khartoum State Abdel Hussein on March 1, 2012 (ICC-PIDS-CIS-SUD-05-004/18_Eng). Hussein was recognized as the closest ally of the Al-Bashir who suspected for recruiting, arming and funding police forces and the Janjaweed militia against rebel force in Darfur (ICC-02/05-01/12-21 \& ICC02/05-01/09). He is still a fugitive. In April 2019, President Omar al-Bashir ousted from his position through the Army coup (BBC, April 11, 2019).

On May 18, 2009, rebel leader Abu Garda voluntarily appeared before the Court in The Hague without issuing a warrant of arrest (BBC, May 18, 2009). On the charge of war crimes committed in an attack against the African Union Peacekeeping Mission, rebel commanders Abdallah Banda and Saleh Jerbo voluntarily appeared in the Court on June 17, 2010. Charges against both rebel leaders were confirmed on March 7, 2011. As a result, warrants of arrest were issued against them on September 11, 2014 (ICC-PIDS-CIS-SUD-04-008/18_Eng).

The Pre-Trial Chamber informed the UN Security Council that the State authority did not cooperate in the cases of war crimes and crimes against humanity. It is to be noted that State senior position holders namely Ahmed Harun, Ali Kushayb, Omar al-Bashir and Abdel Hussein are termed as fugitives (Tladi, 2015). The Pre-Trial Chamber hearing to confirm the charges against Abu Garda took place starting from October 19 to 20, 2009, but refused the charges against him on February 8, 2010 (ICC-02/05-02/09). The Chamber rejected the Prosecutor's application for Abu Garda to appeal the decision and charges were dismissed on February 8, 2010.

On March 3, 2015, the Appeals Chamber rejected Abdallah Banda's appeal against the decision of the Trial Chamber replacing the summons to appear by warrant of arrest (ICC-PIDS-CISSUD-04-008/18_Eng), but he remains at large, fugitive (ICC-PIDS-CIS-SUD-04-006/15_Eng). Jerbo's case was terminated in October 2013 as he was killed in a battle with the same splinter group on April 19, 2013 (Dabanga, October 4, 2013 and ICC-PIDS-CIS-SUD-04-006/15_Eng). None of the leaders attended before the Court following its warrants of arrest, on the one hand. On the other, these criminal cases have been remaining in the Pre-Trial stage until the suspects are presented to the courtroom.

The Office welcomes the Council's strong appeal in UNSCR 2340 for justice in Sudan ensuring accountability on human rights violations and violations of international humanitarian law by whomsoever perpetrated (S/RES/2340, February 8, 2017). The Office of the Prosecutor regrets having the Security Council not taking any action against finding non-compliance of $\mathrm{Al}$ Bashir and other fugitives arrested and surrendered to the Court in the Darfur situation. International and non-governmental organizations express difficulties assisting the Court fearing that their cooperation may leave a great impact on their activities of the project on the ground in Sudan (International Criminal Court, June 8, 2017).

The Republic of Kenya: Kenya has been the ICC State Party since March 15, 2005 (Human Rights Watch, January 2011). Based on the article (25)(3)(a) of the Rome Statute, President Uhuru Kenyatta and Francis Muthaura (Head of Civil Service) were accused of crimes against humanity (ICC-01/09-02/11, March 13, 2015) regarding the context of the 2007-2008 postelections violence in Kenya. Their charges were confirmed on January 23, 2012 through charges of hearing from September 21 to October 5, 2011 (ICC-PIDS-CIS-KEN-02-014/15_Eng 
\& ICC-01/09, November 26, 2009). On December 5, 2014, the Prosecutor filed a notice to withdraw charges against Kenyatta and Muthaura (VOA, December 13, 2016). Trial Chamber terminated Kenyatta's case proceedings and vacated the summons to appear or charges withdrawn against Kenyatta on March 13, 2015 (ICC-PIDS-TCT-01-090/18_Eng \& Wanyeki, August 2012) and proceedings terminated on March 13, 2015. Public approval of President Kenyatta rose significantly after his appearance at the International Criminal Court in October 2014 (Ongiri, October 15, 2014).

\begin{tabular}{|c|c|c|c|c|c|c|}
\hline$\#$ & $\begin{array}{c}\text { Name of inductee } \\
\text { or Suspect }\end{array}$ & $\begin{array}{c}\text { Situation } \\
\text { in }\end{array}$ & Profession & Charge & $\begin{array}{c}\text { Date of } \\
\text { Indictment }\end{array}$ & Current Status \\
\hline 1 & Ahmad Harun & \multirow{4}{*}{$\begin{array}{l}\text { Darfur } \\
\text { (Sudan) }\end{array}$} & Minister & \multirow{2}{*}{$\begin{array}{l}\text { Crimes against } \\
\text { humanity }\end{array}$} & \multirow{2}{*}{$\begin{array}{l}\text { Arrest warrant } \\
\text { of issued on } \\
\text { April 27, } 2007\end{array}$} & \multirow{2}{*}{$\begin{array}{l}\text { Fugitive, remains at } \\
\text { large. }\end{array}$} \\
\hline 2 & Ali Kushayb & & $\begin{array}{l}\text { Army } \\
\text { Commander }\end{array}$ & & & \\
\hline 3 & Abdel Hussein & & $\begin{array}{l}\text { Former } \\
\text { Defense } \\
\text { Minister }\end{array}$ & $\begin{array}{l}\text { War crimes and } \\
\text { crimes against } \\
\text { humanity }\end{array}$ & $\begin{array}{l}\text { Warrant of } \\
\text { arrest issued } \\
\text { on March 1, } \\
2012\end{array}$ & $\begin{array}{l}\text { He recognized as a } \\
\text { closest ally of the Al- } \\
\text { Bashir. Fugitive, } \\
\text { remains at large. }\end{array}$ \\
\hline 4 & Omar Al-Bashir & & President & $\begin{array}{l}\text { War crimes, } \\
\text { crimes against } \\
\text { humanity and } \\
\text { genocide }\end{array}$ & $\begin{array}{l}\text { Arrest warrant } \\
\text {-I of issued on } \\
\text { Mar 4, } 2009\end{array}$ & $\begin{array}{l}\text { Arrest warrant-II was } \\
\text { issued on July } 12,2010 . \\
\text { Fugitive, remains at } \\
\text { large. }\end{array}$ \\
\hline$\overline{5}$ & Abdallah Banda & $\begin{array}{l}\text { Darfur } \\
\text { (Sudan) }\end{array}$ & $\begin{array}{l}\text { Rebel } \\
\text { Commander }\end{array}$ & $\begin{array}{l}\text { War crimes, } \\
\text { attacked against } \\
\text { AU } \\
\text { Peacekeepers }\end{array}$ & $\begin{array}{l}\text { Summons } \\
\text { issued on Aug. } \\
27,2009\end{array}$ & $\begin{array}{l}\text { Warrant of arrest issued } \\
\text { on September } 11,2014 . \\
\text { Fugitive, remains at } \\
\text { large. }\end{array}$ \\
\hline 6 & Walter Barasa & \multirow{3}{*}{ Kenya } & \multirow{3}{*}{$\begin{array}{l}\text { Agent of } \\
\text { bribery- } \\
\text { घुसखोरि } \\
\text { (intruder?) }\end{array}$} & \multirow{3}{*}{$\begin{array}{l}\text { Corruptly } \\
\text { influencing } \\
\text { Court's } \\
\text { prosecution } \\
\text { witnesses }\end{array}$} & $\begin{array}{l}\text { Arrest warrant } \\
\text { issued on } \\
\text { October 2, } \\
2013\end{array}$ & $\begin{array}{l}\text { This was a first such } \\
\text { case. Fugitive, remains } \\
\text { at large. }\end{array}$ \\
\hline 7 & Paul Gicheru & & & & \multirow{2}{*}{$\begin{array}{l}\text { Arrest warrant } \\
\text { issued on } \\
\text { March 10, } \\
2015\end{array}$} & Both were arrested. \\
\hline$\overline{8}$ & Philip Bett & & & & & $\begin{array}{l}\text { They are in Kenyan } \\
\text { custody. Fugitive, } \\
\text { remains at large. }\end{array}$ \\
\hline 9 & Saif Al-Islam Gaddafi & Libya & $\begin{array}{l}\text { Former de } \\
\text { facto Prime } \\
\text { Minister }\end{array}$ & $\begin{array}{l}\text { Crimes against } \\
\text { humanity }\end{array}$ & $\begin{array}{l}\text { Arrest warrant } \\
\text { issued on June } \\
27,2011\end{array}$ & $\begin{array}{l}\text { Fugitive, remains at } \\
\text { large. He was arrested } \\
\text { and he is in Libyan } \\
\text { custody. }\end{array}$ \\
\hline 10 & Al-Tuhamy Khaled & Libya & $\begin{array}{l}\text { Lieutenant } \\
\text { General of the } \\
\text { Army }\end{array}$ & $\begin{array}{l}\text { War crimes and } \\
\text { crimes against } \\
\text { humanity }\end{array}$ & $\begin{array}{l}\text { Arrest warrant } \\
\text { issued on April } \\
18,2013\end{array}$ & $\begin{array}{l}\text { Fugitive, remains at } \\
\text { large. }\end{array}$ \\
\hline 11 & $\begin{array}{l}\text { Mahmoud Al- } \\
\text { Werfalli }\end{array}$ & Libya & $\begin{array}{l}\text { Commander } \\
\text { of the Army }\end{array}$ & War crimes & $\begin{array}{l}\text { Arrest } \\
\text { warrant-I } \\
\text { issued on Aug } \\
15,2017\end{array}$ & $\begin{array}{l}\text { Arrest warrant-II issued } \\
\text { on July } 4,2018 . \\
\text { Fugitive, remains at } \\
\text { large. }\end{array}$ \\
\hline 12 & Joseph Kony & \multirow{2}{*}{ Uganda } & $\begin{array}{l}\text { Rebel } \\
\text { Commander }\end{array}$ & \multirow{2}{*}{$\begin{array}{l}\text { Crimes against } \\
\text { humanity and } \\
\text { war crimes }\end{array}$} & \multirow{2}{*}{$\begin{array}{l}\text { Arrest warrant } \\
\text { issued on July } \\
8,2005\end{array}$} & \multirow[t]{2}{*}{$\begin{array}{l}\text { Fugitive, remains at } \\
\text { large. }\end{array}$} \\
\hline 13 & Vincent Otti & & $\begin{array}{l}\text { Rebel Deputy } \\
\text { Commander }\end{array}$ & & & \\
\hline 14 & $\begin{array}{l}\text { Sylvestre } \\
\text { Mudacumura }\end{array}$ & DR Congo & $\begin{array}{l}\text { Rebel } \\
\text { Commander }\end{array}$ & $\begin{array}{l}\text { War crimes and } \\
\text { Crimes against } \\
\text { humanity }\end{array}$ & $\begin{array}{l}\text { Arrest warrant } \\
\text { issued on July } \\
13,2012\end{array}$ & $\begin{array}{l}\text { Fugitive, remains at } \\
\text { large. }\end{array}$ \\
\hline 15 & Simon Gbagbo & Ivory Coast & $\begin{array}{l}\text { Vice- } \\
\text { President }\end{array}$ & $\begin{array}{l}\text { Crimes against } \\
\text { humanity }\end{array}$ & $\begin{array}{l}\text { Warrant of } \\
\text { arrest issued } \\
\text { by the ICC on } \\
\text { November } 22 \text {, } \\
2012\end{array}$ & $\begin{array}{l}\text { Ivorian authorities } \\
\text { arrested and sentenced } \\
\text { her (first lady) to } 20 \\
\text { years' imprisonment, } \\
\text { but granted amnesty } \\
\text { after } 3 \text { years. }\end{array}$ \\
\hline
\end{tabular}

On 5 April 2016, Trial Chamber by majority terminated the cases against William Ruto and Joshua Arap Sang on the basis of the evidence presented to the Chamber (ICC-PIDS-TCT-01090/18_Eng). The case of Henry Kosgey was also dismissed by the Judges on January 23, 2012 
(ICC-01/09-01/11). All were charged with crimes against humanity committed in the context of 2007-2008 post-election violence in Kenya (ICC-PIDS-CIS-KEN-01-012/14_Eng). Paul Gicheru (a lawyer) and Philip Bett residing in Kenya were suspected of offenses against the administration of justice to influence the Prosecution witnesses (ICC-01/09-01/15). Similarly, Walter Barasa is also charged with offenses against the administration of justice influencing three ICC witnesses (ICC-01/09-01/13). All three suspects have been in pre-trial stages owing to absence 'fugitives' in the Court's custody. However, Gicheru and Bett are in the custody of Kenyan authorities so as not to attend at the ICC. The Court summonsed to appear issued on March 8, 2011 for Mohammed Hussein Ali, Military Commander of Kenya on the charges of crimes against humanity, however, his case was dismissed in the lack of testimonies and evidence (CC-PIDS-CIS-KEN-02-005/12_Eng).

The Republic of Uganda: Uganda is a state-party to the Rome Statute from June 2002. While Lord Assistance Army or LRA (an armed group) initiated an armed insurgency against the Government of Uganda and its army, the Government referred the situation of Uganda to the office of the Prosecutor at the ICC on December 16, 2003. On May 6, 2005, amended and supplemented on May 13, 2005 and additionally on May 18, 2005, the Prosecutor submitted for the action and the Pre-Trial Chamber issued warrants of arrest for crimes against humanity and war crimes to Joseph Kony, Vincent Otti, Raska Lukwiya, Okot Odhiambo and Dominic Ongwen on July 8, 2005. On September 27, 2005, Pre-Trial Chamber requested DR Cong to search for, arrest, detain and surrender to the Court to all five suspects (ICC-PIDS-CIS-UGA001-006/18_Eng).

On January 21, 2015, Ongwen was transferred to the Court's Detention Center. On March 23, 2016, the Pre-Trial Chamber confirmed his charges. The trial resumed on September18, 2018 and defense started on September 27, 2018 (ICC-PIDS-CIS-UGA-02-013/18_Eng and ICC-PIDSTCT-01-090/18_Eng ). His case is continuing. But, Kony and Otti remain at large, 'fugitives' even more than 10 years issuance of the warrants of arrest (ICC-02/04). Raska Lukwiya (killed by the state security forces on August 12, 2006) (ICC-02/04-01/05-270) and Okot Odhiambo (killed on October 27, 2013) proceedings were terminated following the forensic confirmation of their death (ICC-02/04-01/05).

Central African Republic (CAR): Former Vice President of DR Congo, Jean-Pierre Bemba was originally charged with war crimes, crimes against humanity and sexual violence including rape on the course of leading militias in neighboring CAR in October 2002 and March 2003 (BBC News, October 19, 2010). He was the alleged President and Commander-in-Chief (at time of warrant) of the Movement for the Liberation of the Congo, a rebel group that turned political party later (ICC-PIDS-TCT-01-090/18_Eng). Bemba was arrested from Brussels based on the warrant of arrest issued by the ICC on May 24, 2008 and transferred to the Court. The ICC granted interim release on August 14, 2009. On June 21, 2016, he was sentenced to 18 years, but Appeals Chamber dismissed (overturned) his ICC Trial Chamber's convictions on June 8, 2018 (Wakabi, October 6, 2016; Sieff, March 21, 2016) and ordered to release him from the detention in June 2018 (Dwyer, June 8, 2018 \& ICC-PIDS-CIS-CAR-01-020/18_Eng). However, he paid Euro 300,000 as fine to the Court (ICC-01/05-01/13).

Aime Kilolo, Jean-Jacques Mangenda, Fidel Babala and Narcisse Arido were found guilty of offenses against the administration of justice intentionally (corruptly) influencing witnesses and soliciting false testimonies of defense witnesses in the case against Bemba at the ICC. Kilolo was sentenced to two and half years' imprisonment and EURO 30,000 as fine whereas Magenda sentenced to two years' imprisonment. Arido was sentenced for 11 months of imprisonment, while Babala was sentenced for 6 months of imprisonment. The time of both 
spent previously in detention were deducted (ICC-PIDS-CIS-CAR-02-013/18_Eng). They are currently not in Court's custody, under appeal (ICC-01/05-01/13 \& ICC-PIDS-CIS-CAR-02012/17_Eng).

On May 30, 2014, the CAR Government situation was referred to the ICC in response to the crimes allegedly committed in its territory since August 1, 2012 (ICC-01/14). Following an independent and comprehensive preliminary examination, the Prosecutor announced the opening of a second investigation in the Central African Republic (CAR - II) on September 24, 2014 in regards to war crimes and crimes against humanity committed since 2012 (ICC, September 24, 2014). The Pre-Trial Chamber recomposed the presiding judges on March 16, 2018 to investigate the cases (ICC-PTCII-01/18).

Libya: While Libya was not a State-party to the Rome Statute, United Nations Security Council (UNSC) asked the ICC for the investigation of war crimes after the fall of Muammar Gaddafi in February 2011 (Wintour, November 4, 2017). The UNSC referred the situation to the ICC, condemning the violence and use of force against civilians that happened under the regime of Muammar Mohammed Gaddafi (ICC-01/11). The investigation was opened in March 2011 on the charge of murder and persecution.

Table 4: Suspected/Inducted Person in the Court's Custody after Charges were Confirmed

\begin{tabular}{|c|c|c|c|c|c|c|}
\hline$\#$ & $\begin{array}{l}\text { Name of } \\
\text { Indicted or } \\
\text { Suspect }\end{array}$ & $\begin{array}{l}\text { Situation } \\
\text { in }\end{array}$ & Profession & Charge & $\begin{array}{c}\text { Date of } \\
\text { Indictment }\end{array}$ & Current Status \\
\hline 1 & Laurent Gbagbo & \multirow{2}{*}{$\begin{array}{l}\text { Ivory } \\
\text { Coast }\end{array}$} & President & \multirow{2}{*}{$\begin{array}{l}\text { Crimes } \\
\text { against } \\
\text { humanity in } \\
\text { post- } \\
\text { electoral } \\
\text { violence }\end{array}$} & $\begin{array}{l}\text { Arrest warrant } \\
\text { issued on Nov. } \\
23,2011\end{array}$ & $\begin{array}{l}\text { Arrested by international } \\
\text { fighters from presidential } \\
\text { residence and transferred. } \\
\text { Became first ex-Head of Nation } \\
\text { to stand trial at Court. }\end{array}$ \\
\hline 2 & $\begin{array}{l}\text { Charles Blé } \\
\text { Goudé }\end{array}$ & & Minister & & $\begin{array}{l}\text { Arrest warrant } \\
\text { issued on Dec. } \\
21,2011\end{array}$ & $\begin{array}{l}\text { Surrendered at the ICC and } \\
\text { charges were confirmed on } \\
\text { December } 11,2014 . \text { His trial } \\
\text { continues. }\end{array}$ \\
\hline 3 & Al-Hassan & \multirow[b]{2}{*}{ Mali } & Rebel & \multirow{2}{*}{$\begin{array}{l}\text { Crimes } \\
\text { against } \\
\text { humanity } \\
\text { and war } \\
\text { crimes }\end{array}$} & \multirow{2}{*}{$\begin{array}{l}\text { Arrest warrant } \\
\text { issued on } \\
\text { March 27, } 2018\end{array}$} & \multirow{2}{*}{$\begin{array}{l}\text { Transferred to the Court's } \\
\text { custody by the Malian authority. } \\
\text { Hearing to charges confirmation } \\
\text { continues. }\end{array}$} \\
\hline 4 & Al Mahdi & & Leader & & & \\
\hline 5 & Dominic Ongwen & Uganda & $\begin{array}{l}\text { Rebel } \\
\text { Commander }\end{array}$ & $\begin{array}{l}\text { Crimes } \\
\text { against } \\
\text { humanity } \\
\text { and war } \\
\text { crimes }\end{array}$ & $\begin{array}{l}\text { Arrest warrant } \\
\text { issued on July } \\
8,2005\end{array}$ & $\begin{array}{l}\text { Transferred to the Court's } \\
\text { custody. Pre-Trial Chamber } \\
\text { confirmed the charges and the } \\
\text { trial resumes. }\end{array}$ \\
\hline 6 & Bosco Ntaganda & DR Congo & $\begin{array}{l}\text { Rebel } \\
\text { Commander }\end{array}$ & $\begin{array}{l}\text { War crimes - } \\
\text { child soldiers } \\
\text { recruitment }\end{array}$ & $\begin{array}{l}\text { Arrest-I } \\
\text { warrant issued } \\
\text { on Aug. 22, } \\
2006 \text { and } \\
\text { arrest-II on July } \\
12,2012\end{array}$ & $\begin{array}{l}\text { Voluntarily surrendered into } \\
\text { the US Embassy in Rwanda and } \\
\text { transferred to ICC. He is in } \\
\text { Court's custody, faced } 30 \text { years } \\
\text { in jail on crimes committed in } \\
\text { DRC. }\end{array}$ \\
\hline & & & & & eneration III & \\
\hline
\end{tabular}

On 27 June 2011, the Pre-Trial Chamber issued three warrants of arrest, namely Muammar Gaddafi, Saif Al-Islam Gaddafi (unspoken successor of Muammar Gaddafi) and Abdullah AlSenussi for their alleged criminal responsibility as crimes against humanity from February to August 2011. However, the arrest warrant against Muammar Mohammed Gaddafi was withdrawn on November 22, 2011 as he was extra-judicially killed by the agitators. Proceedings against Al-Senussi in the ICC ended on July 24, 2014 when the Pre-Trial Chamber declared his case inadmissible before the ICC (ICC-PIDS-CIS-LIB-01-013/18_Eng). In July 2015, he was sentenced to death by the Libyan Court, but the verdict was under appeal (BBC News, 
October 16, 2015). The Libyan authority failed to comply with the requests of the Court to surrender Saif Al-Islam Gaddafi to the Court (ICC-PIDS-TCT-01-090/18_Eng) and he remains at large, 'fugitive'. The matter was reported to the UN Security Council. Saif was arrested on November 19, 2011 and since then he has been in custody of the Libyan authorities.

Similarly, Al-Tuhamy Mohamed Khaled and Mahmoud Mustafa Al-Werfalli were charged with crimes against humanity and war crimes respectively allegedly committed in February through August 2011. The warrant of arrest of Khaled was issued in April 2017 (ICC-PIDS-CIS-LIB-02002/18_Eng). The arrest warrant against Mahmoud Al-Werfalli was issued on August 15, 2017 by the Pre-Trial Chamber (ICC-PIOS-CIS-LIB-03-003/18). Their cases are in Pre-Trial Stage and both are not in the Court's custody (ICC, May 9, 2018), recognize as fugitive.

Mali: The situation was referred to the ICC by the Government of Mali on July 13, 2012. On January 16, 2013, the ICC opened an investigation on crimes committed on the territory of Mali since January 2012 (ICC-PIDS-TCT-01-090/18_Eng). Ahmad Al Mahdi, an alleged member of the Ansar Eddine (associated with Al Qaeda movement) was charged with war crimes responsible for intentionally directing attacks against historic monuments and religious buildings including nine mausoleums and one mosque in Timbuktu committed within 11 days (June 30, 2012 and July 10, 2012). The warrant of arrest was issued against him on September 18, 2015 (https://www.icc-cpi.int/mali/al-mahdi/pages/alleged-crimes.aspx). On September 27, 2016, Al Mahdi was found guilty by the ICC Trial Chamber and sentenced for 9 years of imprisonment (ICC-01/12-01/15-171). He was arrested and transferred to The Hague on September 26, 2015. The ICC directed for reparations to the victims on August 17, 2017 (ICCPIDS-CIS-MAL-01-08/16_Eng). Al Mahdi was liable for Euro 2.7 million in expenses for individual and collective reparations for the community of Timbuktu (ICC-PIDS-CIS-MAL-0108/16_Eng).

\begin{tabular}{|c|c|c|c|c|c|c|}
\hline$\#$ & $\begin{array}{l}\text { Name of } \\
\text { Inductee or } \\
\text { Suspect }\end{array}$ & $\begin{array}{l}\text { Situation } \\
\text { in }\end{array}$ & Profession & Charge & $\begin{array}{c}\text { Date of } \\
\text { Indictment }\end{array}$ & Current Status \\
\hline 1 & Aime Kilolo & \multirow{4}{*}{ CAR } & $\begin{array}{l}\text { Lead } \\
\text { Defense } \\
\text { Counsel for } \\
\text { Bemba }\end{array}$ & \multirow{4}{*}{$\begin{array}{l}\text { War } \\
\text { crimes and } \\
\text { crimes } \\
\text { against } \\
\text { humanity }\end{array}$} & \multirow{4}{*}{$\begin{array}{l}\text { November } \\
20,2013\end{array}$} & \multirow{4}{*}{$\begin{array}{l}\text { In 2014, Pre-Trial Chamber ordered to } \\
\text { all suspects to appear for trial. They } \\
\text { are currently not in Court's custody, } \\
\text { under appeal. } \\
\text { - Kilolo: Sentenced two and half } \\
\text { years' imprisonment and EUR } \\
30,000 \text { as fine. } \\
\text { - Mangenda: Sentenced two years' } \\
\text { imprisonment. } \\
\text { - Babala: sentenced to six months' } \\
\text { imprisonment (ICC-01/05-01/13- } \\
\text { 749). } \\
\text { - Arido: Sentenced to } 11 \text { months' } \\
\text { imprisonment. }\end{array}$} \\
\hline 2 & $\begin{array}{l}\text { Jean-Jacques } \\
\text { Mangenda }\end{array}$ & & $\begin{array}{l}\text { Defense } \\
\text { Case } \\
\text { Manager } \\
\text { for Bemba }\end{array}$ & & & \\
\hline 3 & Fidele Babala & & \multirow[b]{2}{*}{$\begin{array}{l}\text { Agent of } \\
\text { bribery for } \\
\text { Bemba }\end{array}$} & & & \\
\hline$\overline{4}$ & Narcisse Arido & & & & & \\
\hline ote. & & & person's a & & & d analysis of Generation III \\
\hline
\end{tabular}

Al-Hassan, an alleged member of the Ansar Eddine and de facto Chief of the Islamic police was allegedly charged with war crimes and crimes against humanity. On March 27, 2018, warrant of arrest was issued against him and he was surrendered to the ICC on March 31, 2018. Confirmation of charges hearing was scheduled for September 24, 2018 (ICC-PIDS-CIS-MAL02-002/18_Eng).

Georgia: Georgia has ratified the Rome Statute on September 5, 2003. On January 27, 2016, the Pre-Trial Chamber opened the war crimes and crimes against humanity investigation that 
occurred during an international armed conflict in Georgia between July 1 to October 10, 2008 (ICC-PIDS-TCT-01-090/18_Eng). A total of 6,335 victims had been in favor to investigate the serious human rights violations by the ICC (ICC-01/15).

Burundi: Burundi has ratified the Rome Statute on September 21, 2004. On November 9, 2017, the Pre-Trial Chamber issued a public statement to open an investigation regarding war crimes and crimes against humanity within the ICC jurisdiction allegedly committed both in and outside of Burundi from April 26, 2015 to October 26, 2017 (ICC-PIDS-TCT-01-090/18_Eng). The preliminary investigation of the situation in Burundi was announced on April 25, 2016. More than 430 persons were reportedly killed that resulted in 3,400 people arrested and over 230,000 Burundians were forced to seek refuge in neighboring countries (ICC-PIDS-TCT-01090/18_Eng). But, Burundi lodged a notification of withdrawal from the Rome Statute with an effect on October 27, 2017 (ICC, December 4, 2017; Ssenyonjo, June 13, 2017 \& BBC, February 1,2017 ) and became the first nation to leave International Criminal Court (The Guardian, October 28, 2017). The Pre-Trial Chamber confirmed Burundi's withdrawal from the Statute that has no effect on the jurisdiction of the Court over crimes allegedly committed during the said period when it was a State Party (Human Rights Watch, October 27, 2016 \& Associated Press, October 7, 2017). Nor does it affect the continuing obligation of Burundi to cooperate with the Court in relation to the investigation (ICC, December 4, 2017: 67).

Ivory Coast: Ivory Coast ratified the Rome Statute on February 15, 2013. Before being a StateParty, the Pre-Trial Chamber granted to open an investigation proprio motu in the situation of Ivory Coast on October 3, 2011. The investigation started based on the acceptance of jurisdiction of the ICC on April 18, 2003, December 14, 2010 \& May 3, 3011 (ICC-02/11). The Court has jurisdiction of crimes against humanity allegedly committed between September 19, 2002 to November 28, 2010 (ICC-PIDS-TCT-01-090/18_Eng).

The then President Laurent Gbagbo was accused of crimes against humanity in the context of post-electoral violence that happened from December 16, 2010 to April 12, 2011. The warrant of arrest was issued on November 23, 2011 and arrested by international fighters from presidential residence (VOA, April 10, 2011) and was transferred to The Hague November 30, 2011. And his charges were confirmed on June 12, 2014. He kept into Court's custody (Kouassi, July 24, 2018), as a sitting Head of Nation to stand trial at the Court, Hague. However, Gbagbo was released by the ICC on January 15, 2019 after being acquitted on charges of crimes against humanity (Aljazeera, February 6, 2019).

In another case, Charles Blé Goudé surrendered on March 22, 2014 and charges were confirmed on December 11, 2014 (ICC-PIDS-CIS-CI-04-03/16_Eng). On January 28, 2016, Trial Chamber opened two cases against Laurent Gbagbo and Charles Blé Goudé and they are ongoing in the Court. A total of 727 persons filed to participate in the proceedings against Gbagbo and Blé Goudé. Both were in ICC's custody (ICC-PIDS-CIS-CI-04-03/16_Eng \& ICC02/11-01/15) till February 2019 only (Aljazeera, February 6, 2019).

Ivory Coast's former first lady, Simone Gbagbo was charged with crimes against humanity allegedly committed during post-electoral violence in December 2010 and April 2011. Ivorian authorities arrested her and sentenced 20 years' imprisonment (Brocchetto, March 10, 2015) but was released as granted amnesty by the President in the name to foster reconciliation on August 7, 2018 (BBC News, August 7, 2018) after serving 3 years imprisonment (Maclean, August 7, 2018). 
Preliminary examinations: The preliminary examinations by the ICC are completed in Palestine I (January 2009-April 2012), South Korea (December 2010-June 2014) and Honduras (November 2009-October 2015), but are conducting in eight countries: Afghanistan (2007-), Colombia (2004-), Gabon (September 2016-), Guinea (October 2009-), Iraq/UK (February 2006-), Nigeria (November 2009-), Palestine II (January 2015-), Philippines (February 2018-), Ukraine (April 2014-) and Venezuela (February 2018-) (https://www.icc-cpi.int).

Palestine I: On January 22, 2009, the Minister of Justice, Government of Palestine, lodged a declaration accepting the jurisdiction of the ICC acts committed on the territory of Palestine since July 1,2002 . The Office of the Prosecutor initiated a preliminary examination in order to determine whether there is a reasonable basis to proceed with the investigation (ICC, April 3, 2012). The ICC stopped the examination stating there had been a lack of jurisdiction (ICC, September 2, 2014). Even though, Minister of Justice Ali Khashan signed the declaration recognizing the jurisdiction of the ICC attending in The Hague on January 21, 2009 (Declaration Recognizing the Jurisdiction of the ICC, January 21, 2009).

South Korea: South Korea has been a State-party to the Rome Statute on November 13, 2002 (https://www.icc-cpi.int/korea). On December 6, 2010, the ICC Prosecutor announced the opening of a preliminary examination to assess whether the incidents happened in the Yellow Sea constituted war crimes under the jurisdiction of the Court (ICC, June 2014). On June 23, 2014, the Prosecutor concluded that there was no need of further investigation on the situation of Korea as the ICC did not find any crimes committed based on a thorough legal and factual analysis of the evidence and information collected there (Press Release: June 23, 2014).

Honduras: Honduras accessed to the Rome Statute on July 1, 2002. The preliminary examination focused on alleged crimes against humanity committed in the aftermath of the coup d'état on June 28, 2009. In November 2013, the Prosecutor concluded that examination did not provide reasonable evidence and testimonies of crimes committed between June 28, 2009 and January 27, 2010 (ICC, October 28, 2015). On October 28, 2015, the ICC finally decided to close the examination (ICC, November 12, 2015).

Afghanistan: On November 20, 2017, the Prosecutor of the ICC requested to initiate an investigation into alleged war crimes and crimes against humanity committed in the Islamic Republic of Afghanistan that occurred after May 1, 2003 (ICC, December 4, 2017). Afghanistan is not a State-party to the Rome Statute, but deposited its instrument of accession on February 10, 2003 in which ICC may exercise its jurisdiction over crimes that committed on the territory of Afghanistan (https://www.icc-cpi.int/afghanistan). On September 11, 2018, the United States of America threatened to arrest and sanction judges and other officials of the ICC if it moved to charge any American who served in Afghanistan (Agency France Presse, September 11, 2018).

Colombia: The preliminary examination of the ICC to Colombia initiated on crimes against humanity and war crimes that were committed after November 2002. Colombia has been a State-party while it accessed the Rome Statute in August 2002 (ICC, November 2012). Transitional justice is to ensure accountability for those who were responsible for the gravest crimes. The cycle of impunity is to be broken and the war crimes and crimes against humanity committed during the armed conflict should not go unpunished (Stewart, May 30-31, 2018). Further investigation and prosecution are the current urgencies for the justice to the victims and to make the perpetrators accountable (ICC, December 4, 2017). 
Gabon: On September 21, 2016, the Government of the Republic of Gabon requested the Prosecutor of the ICC to open an investigation without delay. One week later, the Prosecutor announced the opening of the preliminary examination over crimes committed in the context of the presidential election of August 2016 (ICC, 2017). The Prosecutor has been continuing on alleged crimes examination thereafter (ICC, December 4, 2017).

Guinea: Guinea accessed the Rome Statute on July 14, 2003. The preliminary examination of the situation in Guinea had been announced on October 4, 2009 on alleged crimes against humanity committed in events in Conakry on September 28, 2009 (https://www.icccpi.int/guinea). The examination receives the most significant progress (ICC, December 4, 2017).

Iraq/the UK: The United Kingdom is a State-party to the Rome Statute. Therefore, the ICC may exercise its jurisdiction over the Rome Statute crimes that are either committed on the territory or by nationals of the United Kingdom as of July 1, 2002 (https://www.icccpi.int/iraq). It is reported that the alleged war crimes committed by the United Kingdom nationals in Iraq conflict and occupation from March 2003 to July 2009 include murder, torture, and other forms of ill-treatment (A/72/349, September 29, 2017). The preliminary examination of the situation in Iraq was initially terminated on February 9, 2006 but was reopened on May 13, 2014 when the European Center for Constitutional and Human Rights and Public Interest Lawyers provided new information on January 10, 2014 against war crimes committed by the United Kingdom nationals in Iraq (ICC, December 4, 2017). In December 2017, Chief Prosecutor Fatou Bensouda of the ICC stated that there are reasonable bases in which British troops had committed war crimes against Iraqi detainees (James Robbins, December 31, 2017). The examination is continuing.

Nigeria: The Federal Republic of Nigeria has been a State-party to the Rome Statute. It allegedly committed war crimes and crimes against humanity in the Niger Delta and the Middle-Belt States by the armed conflicting actors: insurgent Boko Haram and Nigerian security forces (Adigun, December 14, 2017). The preliminary examination of the situation in $\begin{array}{lllll}\text { Nigeria was opened } & \text { November }\end{array}$ (http://www.coalitionfortheicc.org/country/nigeria). On November 12, 2005, the eight potential cases (six conducted by Boko Haram and two by the Nigerian security forces) were reported as allegedly committed crimes against humanity and war crimes (ICC, November 12, 2015). The ICC continues to examine the crimes committed against the children and collect further information on relevant domestic proceedings to identify the pending impunity gaps and possible remedial measures (ICC, December 4, 2017 \& Amnesty International, 2018).

Palestine II: Palestine has been the State-party to the Rome Statute since January 2, 2015. On January 16, 2015, the Prosecutor announced to open the preliminary examination into the situation in Palestine in order to allege crimes committed in the Palestinian territory, including East Jerusalem that has been occupying since June 13, 2014 (https://www.icccpi.int/palestine). The Prosecutor office is assessing and reviewing jurisdictional issues within a reasonable time frame (ICC, December 4, 2017:12-19). The ICC has become a Court of last hope of option for Palestinians (Kiswanson, May 28, 2018). The Palestinian Government has submitted a referral to the ICC (calling to the Prosecutor) to open an immediate investigation in Israeli crimes in the occupied Palestinian territories (Tahhan, May 22, 2018) completing its preliminary examination soon.

Philippines: The Philippines has been a State-party to the Rome Statute since November 1, 2011. The ICC announced to open the preliminary examination of the situation in the 
Philippines on February 8, 2018 over the crimes of war against drugs (use or dealing) campaign committed by the Government of the Philippines since July 1, 2016 (ICC, February 8, 2018; Rappler, March 14, 2018). It is allegedly reported that more than 4,000 people were killed by the police in the name of encounters, anti-drug operations and clashes between or within gangs. On March 13, 2018, The Philippines notified the United Nations SecretaryGeneral of its decision to withdraw from the International Criminal Court (ICC), but has assured the UN of its commitment to the rule of law (Reuters, March 16, 2018).

Ukraine: Ukraine has not been a State-party to the Rome Statute (https://www.icccpi.int/ukraine), but the Government of Ukraine accepted the ICC's jurisdiction through declarations on April 14, 2014 and September 8, 2015 over alleged crimes committed on its territory (November 21, 2013 to February 22, 2014) and onwards (Global Rights Compliance, December 2016). The examination over the crimes has been continuing (ICC, December 4 , 2017).

Venezuela: A State-party to the Rome Statute, the ICC opened its preliminary examination in Venezuela on February 8, 2018 (https://www.icc-cpi.int/venezuela). It has been analyzing crimes allegedly committed since April 2017, in the context of demonstrations and related political violence and or unrest (OAS, May 30, 2018). The examination is still going on.

Syria: There has been all-round pressure to establish the ICC to prosecute the heinous and systematic crimes (nearly 10 million displaced and over 500,000 civilian casualties) against humanity committed by the Syrian President Bashar al-Assad and members of his regime (Killingsworth, March 13, 2019). However, the outcome is still uncertain.

A total of 42 suspected individuals have publicly been indicted by the Court's Pre-Trial Chambers by the end of 2018. Among them, the Court has issued warrants of arrest for 33 suspected persons and nine others were a summons to appear into the Court voluntarily. The nine suspects are: six William Ruto, Joshua Arap Sang, Uhuru Kenyatta, Walter Barasa, Paul Gicheru and Philip Kipkoech Bett from Kenya and three alleged perpetrators: Bahr Abu Garda, Abdallah Banda and Saleh Jerbo from Darfur (Sudan) (ICC-01/09-01/15 \& ICC-PIDS-CIS-LIB01-011/15_Eng).

The Generation-III refers that the domestic criminal jurisprudence notion shall be changed to International Tribunal if concerned country's civil law (law of nation) and natural law could not guarantee justice to the victims, survivors and society at large. Thus, the Generation-III shall have the jurisdiction that tends to prosecute and punish suspected individuals under the international war crimes, crimes of genocide, crimes against humanity and crimes of aggression.

It is obvious that the working methodology and investigation process of the ICC are slow and complex. Out of 123 States Parties, the powerful countries such as the USA, China, Russia, India, Britain among others had not been a State-Party to the Rome Statute (Latiff, October 12, 2013). Such Non-State Party does everything to influence and control the personnel of the ICC. In March 2019, the US Government imposed visas bans to the ICC staffs if the ICC investigates the US citizens and its allies (Human Rights Watch, March 15, 2019, The Guardian, March 15, 2019; The Guardian, April 5, 2019). President Kenyatta stated that powerful Western imperialists who were even not a party to the Rome Statute turned the Court to a tool for manipulation and neo-colonialism in the African States (Latiff, October 12, 2013). Till the end of March 2019, four developing countries namely South Africa, Burundi, Gambia, and the Philippines have withdrawn from the Rome Statute of the International Criminal Court. 


\section{GENERATION-IV: A NOTION CHANGED FROM SECTARIAN VIOLENCE TO RECONCILE JUSTICE}

A few TJ bodies, for instance, Citizens' Truth Commission (Kandy, Sri Lanka), Greensboro Truth and Reconciliation Commission (USA) and Truth and Reconciliation Commission (Canada) were formed to investigate the past human wrongdoings (atrocities and crimes) whose human rights were violated and/or abused by the groups of non-State actors. The inter-religious violence happened in Sri Lanka, communal apartheid occurred in Carolina and cultural genocide ensued in Canada.

Citizens' Truth Commission of Kandy, Sri Lanka: On February 22, 2018, three Muslim youngsters brutally attacked a Sinhalese lorry driver from Ampara town, who died at the hospital on March 2, 2018 (Perera \& Siriwardana, March 6, 2018). A series of religious riots targeting the minority Muslims began in Ampara town, Sri Lanka on February 26, 2018. The attack took place after a group of people accused a Muslim owned shop of mixing some pills in the food (Colombo Gazette, February 27, 2018). The anti-Muslims, particularly Singhalese Buddhists attacked Muslim shops, people, mosques and their other properties and the Muslims also attacked Buddhist temples and Singhalese citizens (The Sunday Leader, February 26, 2018).

On March 6, the Government of Sri Lanka imposed a nationwide state of emergency for 10 days to take the riots under control when the riots spread to Kandy (The Hindu, March 6, 2018), but the state of emergency was the first ever of such nature since 2011. The riots were denounced by the Buddhist monks and many Sinhalese and rallied to protect and help Muslims and Mosques during the prayers across the country (Nazeer, March 8, 2018). Two died and ten were reported of injuries among Sinhalese, Muslims and Police. However, 4 mosques, 37 houses, 46 shops and 35 vehicles were destroyed as a result of the riots in both Digana and Kandy District and others (Hiru News, March 5, 2018).

Under the National Peace Council, Kandy District Inter-Religious Committee set up 11-member Citizens' Truth Commission headed by a retired judge on June 7, 2018 to find out root causes of violence (The National Peace Council of Sri Lanka, June 7, 2018). The sole purpose to establish Commission was to minimize the radicalism in Sri Lanka. The Commission finally submitted a Report on December 18, 2018. The abstract of the Report has been given below:

- The driver was attacked by the Muslim youngsters.

- The Muslim community was taking steps to compensate the family of the victim by paying a sum of Rs. 1,700,000.

- Since no actions were taken to stop the procession, hundreds of individuals joined at the said rally and came to Digana town and attacked the Muslim's religious worship places, their properties and have set fire on properties and vehicles as well.

- Unknown (veiling their faces) group of villagers, youngsters between 18 to 25 years and racist groups of the villages guided them to visit the town and attacked Muslims houses and shops.

- Certain Buddhist monks and Buddhist temples had supported for that outbreak of violence, but Buddhist religious places, local Buddhist monks and humanitarian organizations had protected the Muslim and Muslims were preserved and supported in many ways.

- Water in the fire truck was wasted by letting it flow on the road instead of extinguishing the fire in the fire zones.

- A sum of Rs. 100,000 had been given to each victim-family by the Government as its part of compensation. 
- Police officials played no roles to protect Muslim communities because of vested political motives.

- The disturbance spread over eleven divisions including Digana, Teldeniya, Akurana, Edarutenna, Uguressapitiya where 297 houses were partially destroyed, 20 Muslim worship places, 223 business places and 65 vehicles were damaged including the death of the driver at the beginning, three deaths and two wounded were reported.

In order to reduce racism and communal acts, the Commission has recommended a number of reconciliatory ways: building reconciliation in schools, punishment to the perpetrators, handling mass media carefully, strengthening civil administration as required, development of rehabilitation of education curriculum, security sector reform, inter-religious harmony and among others (December 18, 2018).

Greensboro Truth and Reconciliation Commission, USA: Against the racial inequalities in education, employment, housing and access to healthcare, Communist Workers Party (CWP) initiated a petition for labor rights of factory workers. On the morning of November 3, 1979, mostly black members of the CWP gathered in Greensboro, North Carolina protested against the social and economic injustices that happened because of leading role of the Ku Klux Klan (white supremacy or white extremist) or KKK and American Nazi Party (ANP) (Hand, November 18, 2004). At 11 AM, about dozen-vehicle convoy containing more than three-dozen members of the KKK and the American Nazi Party arrived and skirmished for a while. The white Klansmen opened their firearms and shot five protesters to death injuring 10 others in less than 2 minutes (Jovanovic, 2012). However, no one was convicted in two criminal trials conducted by all-white judges (Fears, March 6, 2005).

The police had full knowledge of the event but did not attain there owing to communist protest and demonstration. People suffer from psychological trauma, depression, anger and fear that exacerbated race and class tensions. People and media widely condemned Klan, Nazi and Greensboro Police Department (Beitler \& Edward, 2013). During the marking of the $25^{\text {th }}$ anniversary of the Greensboro massacre, the seven-member ( 5 women and 2 men) Greensboro Truth and Reconciliation Commission was formed on May 27, 2004. The seven commissioners, a respected group of individuals were selected for their diverse perspectives, strengths and resolve to fulfill their mandate. The Greensboro Commission was an independent, democratically selected body that investigated the truth for healing transformation for Greensboro victims and survivors (Greensboro Truth and Reconciliation Commission, May 25, 2006).

Initially, the Commission encountered a huge difficulty in collecting statements and testimonies from the victims or survivors as concerned individuals expressed their worry whether the Commission's mandate and its ability shall effect durable social change. However, the Commission had been able to receive cooperation from survivors and other concerned individuals in which they conducted one-on-one interviews. It collected 145 oral statements including testimonials of 17 demonstrators, 14 individuals from the-then Morningside Homes along with seven written accounts, six current/former Greensboro police officers, five current/former members of the KKK and the American Nazi Party, and a judge. Public hearings were also conducted with significant police presence for safety. All five of the victims' widows provided permission to the Commission to grant immunity to any perpetrator willing to offer a testimonial, information and statements (Margarnell \& Wesley, 2008).

On May 25, 2006, the Commission released its final 500-page report to the public. The report stated that Nelson Johnson simply had a plan to march for the purposes of promoting social, 
economic and racial justice and had taken permission from the Greensboro Police Department, listing Morningside Homes as the starting point for the march. But, the police also gave permission to Klan members. However, police officials had already known the KKK and the Nazi Party, and the Communist Party previous confrontation. The KKK and Nazis acted the direct violation of the protesters' right of free speech and their right to assemble. When police officers went Morningside Homes to investigate an act of domestic violence, they were intentionally called back by their white superiors. The Report adequately stated that the massacre had happened because of the negligence of the police and their some connection with KKK and Nazis (Greensboro Truth and Reconciliation Commission, May 25, 2006).

The Commission recommended Greensboro Police to announce public and private apologies (Jovanovic, 2012) and reparations and compensation to the victims and survivors. The report further recommended launching some anti-racist programs and need to reform institutional practices of local government by paying its city workers a fair and decent wage. It recommended expanding the lists of potential inclusive juries, so that all future juries could fairly represent the community by avoiding the selection of all-white juries. It suggested strengthening social and economic justice in the entire region (Greensboro Truth and Reconciliation Commission, May 25, 2006).

Truth and Reconciliation Commission, Canada: In 2006, Canada negotiated the Indian Residential Schools Settlement Agreement among the federal government, representatives of former students at residential schools, the Assembly of First Nation, Inuit representatives and several church organizations (Walker, February 11, 2009). The Truth and Reconciliation Commission (TRC) was officially established on June 2, 2008 with the purpose of collecting the testimonies and evidence on the course of documenting the history and its impacts of the Canadian-Indian residential school system towards indigenous aboriginal people. The testimonies and evidence were collected (telling the truth stories) by the residential schools students or survivors and their families, religious entities, former student employees, government and people of Canada (http://www.residentialschoolsettlement.ca/SCHEDULE_N.pdf). The Commission heard (telling the truth stories) from more than 6,000 witnesses, mostly those who survived and shared experiences of living in the schools as students (Truth and Reconciliation Commission, 2015).

The TRC on Canada's Indian residential schools uses the term 'cultural genocide' for 150,000 aboriginal children and their families during 120-year history who were forced to attend schools (Schwartz, June 2, 2015). Many of those children were sexually and physically abused (Moran, September 24, 2015). The TRC collected testimonies of 6,000 (dead) aboriginal children who were taken away from their families, and buried in unmarked graves without informing their parents. There were 31,970 serious sexual assault resolved cases and 5,995 claims are still in progress (Schwartz, June 2,2015). The TRC commissioners conducted formal community hearings across the country, visiting more than 70 communities and many others for community events. The commission found approximately 3,200 residential school students died because of malnourishment, tuberculosis and other diseases owing to poor living conditions (Moran, September 24, 2015).

It recommended "94 Calls to Action" for changes in policies and programs. The calls for action belonged to child welfare, education, language and culture, health and justice (Truth and Reconciliation Commission, 2015). A number of reconciliation measures were also recommended. It was recognized as an integrated part of cultural genocide (Truth and Reconciliation Commission of Canada, 2015). There had been high hopes with the TRC that it 
would repair the relationship between the aboriginal people and the rest of Canada, but it failed (Walker, June 1, 2015). On June 2008, the then Prime Minister Stephen Harper apologized for the role of past government administration in the residential schools (Statement of apology to former students of Indian Residential Schools, June 11, 2008). The TRC office was closed on December 18, 2015 after publishing the final report.

Prime Minister Justin Trudeau who attended at the report release expressed his commitment to implement all of the 94 recommendations. The Trudeau Government began working towards to form a national inquiry into missing and murdered indigenous women and girls. In response of TRC Chair Justice Murray Sinclair, "Canada must move from apology to action," on November 24, 2017, PM Trudeau formally apologized to survivors of residential schools in Newfoundland and Labrador (CBC News, November 24, 2017 \& Czyzewski, 2011).

The National Center for Truth and Reconciliation (NCTR) was established at the University of Manitoba in Winnipeg to develop the archive to hold the research, documents and testimonies collected by the TRC. In November 2015, the NCTR was opened to the public which developed a library of more than five million documents relating to the legacy of residential schools in Canada (Dehaas, November 3, 2015).

In this section, a notion of the Generation-IV changes sectarian lines of violence to reconcile justice across the groups or communities. The sectarian violence is no less than communal violence. Generally, the communal violence refers to ethno-religious violence, racial violence, non-state to non-state violence, and among others. For this, violent parties have a high moral of solidarity to their respective institution, community or group based on their membership. Reconcile justice restores friendly or compassionate relations allowing for transactional justice. Transactional justice depends upon liability and necessity.

The communal violence can erupt any time anywhere in the world owing to zest and zeal of institutions and individuals. The ultimate goal of society, nation and the universe is to achieve free and fair justice to the victims-survivors digging out the truths of the violence that makes accountable to the perpetrators. Free and fair justice transforms the deeply divided societies through forgiveness and reconciliation. The reconciliation heals the wounds of the victimssurvivors which need to be addressed following the interest and need of concerned individuals, formulating or amending the laws, making aware the state and non-state actors, pressing the players of political dimensions and following the norms and principles of international phenomena. Transformation recovers from internecine strife changing concerned institution and individual's notion, attitude and behavior towards harmony, justice and peace dividend.

\section{GENERATION-0: A NOTION YET CHANGED FOR JUSTICE ESTABLISHING TRUTH COMMISSION}

A number of post-conflict countries have yet to form the Truth Commissions respecting the voices of international and national pressure groups, need of the victims, survivors and society at large, and to make the perpetrators accountable.

Angola: After independence from Portugal, a protracted people's liberation struggle was staged by three separate movements (civil war) for 27 years. The civil war has left deep emotional and political scars among the populace (Redvers, February 6, 2015). The TRC did not establish in Angola, but a blanket amnesty for all those involved in the civil war was introduced to the past crimes and atrocities through the peace declaration in 2002 (Wijk, 2012). The possibility of national leaders being brought to trial and justice to the victims has been a thin cry (Human Rights Watch, July 7, 2009). 
Bosnia-Herzegovina: Several initiatives for Bosnia-Herzegovina were conducted to establish a national TRC during 1997-2006 but they failed to implement it (Dragovic-Soso, 2016). Despite the considerable international efforts to create a TRC for Bosnia, all attempts failed because of political resistance, institutional rivalry between the ICTY (International Criminal Tribunal for the Former Yugoslavia) and the TRC project, and the TRC project's lack of legitimacy with Bosnia's victim associations (Basic, Undated). The failed attempt of TRC in Bosnia provides important lessons for ongoing truth-seeking in post-conflict societies. While international voices were strong enough to establish a TRC there, Bosnian citizens especially victims refused international intervention (Fischer, 2007). International pressure is not enough to establish the Truth Commission if internal political will dare to reject it. No single theoretical concept explains why Bosnia-Herzegovina is unable to create a Truth and Reconciliation Commission, but multiple functional and institutional concepts and vested interests left impact there (Kramm, 2012).

Cyprus: The conflict of Cyprus between the Greek and Turkish Cypriot communities from 1963 to 1974 led to ethnic cleansing (www.ictj.org/our-work/regions-and-countries/cyprus). There has been a high public pressure to construct a TRC similar to the South African model with the hope of that the truth of the past will bring reconciliation among the societies (Yakinthou, August 28, 2016). Some cynic society members argue that "truth commissions have been divided by politics, and this has hurt victims and also discredited the work of the commission" (Yakinthou, August 28, 2016).

Czech Republic: Besides the Truth Commission, the Czech criminal subdivision of police investigated criminal acts for the period 1948-1989 that happened during the past Czechoslovak communist regime. It was established by the decision of the Minister of the Interior on January 1, 1995 (Czech Republic Police, June 1, 2008). The police subdivision has no authority to work independently and autonomously.

Eretria: The United Nations Human Rights Council established a 3-member team under the Commission of Inquiry on Human Rights in Eretria on June 27, 2014 to investigate all alleged violations and abuses of human rights in Eritrea. The Commission extended its mandate for one year to June 2016 (June 1, 2016). International community vocals to establish the Truth Commission as the present authoritarian regime closed all independent newspapers and human rights organizations, arrested their journalists, and government officials and others who critic against the President Isaias Afwerki (Human Rights Watch, April 27, 2018). The Report concludes that crimes against humanity prevails in the country (Human Rights Council, June 8, 2016), however, the formation of the Truth Commission is not possible till Afwerki stays in power.

Fiji: In May 2005, the Government proposed Reconciliation, Tolerance, and Unity Bill to pass from Fijian Parliament. The Bill has a purpose to empower the Commission to grant amnesty to perpetrators who were directly involved in the Coup of 2000 and compensate to victims of it (May 19, 2000 through March 15, 2001). The Bill incorporated that the President would retain a veto over the granting of amnesty (Bhim, 2007). Because of the blanket amnesty to the coup aggressors, the Bill was sharply denounced by the political parties, the international community and the Army. Finally, the military Commander Frank Bainimarama overthrew the Government 'coup within a coup' on December 5, 2006 (International Bar Association, 2005). Thus, the dream to establish the TRC to provide a blanket amnesty to the perpetrators has ended forever in Fiji. 
Georgia: The Truth, Justice and Reconciliation Commission for Georgia was to investigate the mass disappearances of people between 1976-1983 and to uncover the truths who involved in those cases. The Commission can be endowed with a range of powers: to summon witnesses and to recommend that some persons are prosecuted in the criminal courts and others pardoned (Dolidze \& Wall, December 12, 2012). The overall goal of the process shall be to make a definite break over the past wrongdoing confronting the root causes of an abusive system (International Center for Transitional Justice, February 2017).

India: Jammu-Kashmir in India is one of the most militarized zones in the world (Singh, July 12, 2016). The disputes arise over local autonomy. Militarized zone controls the life and liberty of a person by draconian legislation (Note 7) practicing excessive use of powers to arbitrary arrest and detention, search and seizure, custodial torture and rape, extrajudicial killing using lethal force and enforced disappearances. It is estimated that over 8,000 people are disappeared from 1989-2006 in Jammu-Kashmir (Sofi, January 17, 2019) alone. More than 500 (out of over 2,000) families of disappeared persons in Jammu-Kashmir have filed complaints before the State Human Rights Commission (SHRC) seeking DNA tests to be conducted on the thousands of unmarked mass graves found in northern Kashmir (NHRC issues notice to the Government of Jammu and Kashmir, Undated). The victims' families filed cases while the State Government of Jammu-Kashmir refused to exhume bodies in unmarked graves and carry out DNA tests to ascertain the family's identity. Even though, at the end of 2017, India ordered to 2,080 mass graves in Kashmir to State-run Human Rights Commission (Fareed, November 3, 2017). No further works to establish the Truth Commission has been initiated. The Central Government of India is reluctant to establish the TRC and investigate the truth fearing the international community's attention on the cause of disappearance there.

Indonesia: The TRC bill was approved on September 7, 2004 to establish a panel of 21 persons for national reconciliation and unity on the course of possible amnesties for repentant perpetrators and reparations for the victims (International Center for Transitional Justice, 2005), but the law annulled two years later without establishing a TRC (Asia Justice and Rights, Undated). In December 2006 Indonesia's Constitutional Court declared the TRC law unconstitutional, on the ground that the TRC law would award amnesties to perpetrators of past crimes. The Court further states that the TRC Law violated Indonesia's international obligations and domestic laws (Human Rights Watch, 2008). Indonesia needs to establish a TRC to address the excessive use of power-the slaughter of half a million suspected communists in the 1960s (Lamb, April 13, 2016).

Kosovo: The majority Kosovo Albanians attacked the minority Kosovo Serbs in March 2004 (July 2004). That sudden attack was known as no less than ethnic cleansed where large numbers of Serbians were killed; thousands were forced to leave their homes, schools and health care centers were demolished and destroyed. Even 11 years afterward, the Serbs of six towns and ten villages who were driven out of their homes have not returned (B92, March 17, 2015). Some critique that reconciliation between these Kosovo Albanians and Serbs cannot live together, but the concerned officials and authorities are mistaken as "reconciliation is not for people who love each other; it is for people who hate each other" (Sverrisson, January 2006). There is a need to establish a Truth Commission for reunion through reconciliation even though the United Nations Interim Administration Mission in Kosovo (UNMIK), one of the longest-running political and territorial missions did not work that much for establishing a Truth Commission. Even the European Union and other concerned actors were not happy with the role of the UNMIK. The UNMIK and NATO-led KFOR failed to protect the Kosovars, building a stable political system and independence of Kosovo (Human Rights Watch, July 26, 2004). Moreover, it completely failed to work for truth-seeking to ensure justice and reparation to the 
victims and prosecute the perpetrators (EU Reporter Correspondence, April 17, 2015). However, President Hashim Thaci established the TRC Preparatory Team in December 2017 (Qamili, December 14, 2017). The Preparatory Team has been consulting with the public on the course to develop the TRC (President of the Republic of Kosovo, April 19, 2019). The TRC may be formed in 2022 .

Namibia: Majority of Namibians demanded that the Truth Commission be established to provide justice to the victims (Dobell, June 1997) and make the perpetrators accountable. However, SWAPO (Namibia) President Sam Nujoma denied establishing the TRC to settle the recovery of mass graves or other deaths occurred during the war before Independence (Maletsky, November 28, 2005). Therefore, no TRC was established in Namibia as most of the perpetrators of apartheid violence are now citizens of South Africa (Moore, January 2015).

Pakistan: Pakistan has been participating in a war against terror (US invasion in Afghanistan) since 2001. A number of people disappeared on the so-called war on terror in connection with the Islamist armed groups. Many of them were handed over to the US invasive force to be imprisoned in the Guantanamo Bay (Khan, August 30, 2008). In the first seven months of 2016, 510 reported cases of forced disappearance took place in Pakistan (Rahman, August 25, 2016). The report of the Working Group on Enforced or Involuntary Disappearance in 2013 said, "In Baluchistan alone...more than 14,000 people are still missing..." (A/HRC/22/45/Add.2, February 26, 2013). International Voice for Baloch Missing Persons says that 18,000 Baloch are currently unaccounted for, where more than 2,000 were killed between 2001 to 2013 (Nazish, January 06, 2014). Human rights groups ask the Pakistani Government to find out the truth of disappeared persons (Nauman \& Shan, January 10, 2017), however, the Government turned to deaf hear to form the TRC.

South Sudan: As part of the 2015 peace agreement, the Ministry of Justice and Constitutional Affairs started wider consultations across the country on May 14, 2018 for the establishment of the Commission on Truth, Reconciliation and Healing (CTRH) (South Sudan, May 14, 2018). The "progress on the Hybrid Court for South Sudan (HCSS) and other transitional justice mechanisms provided for in the August 2015 Peace Agreement has stalled" (Amnesty International, February 12, 2019). Besides, UN Human Rights Commission in South has continuously been investigating crimes under international law and other gross human rights violations or abuses committed during the past conflict, and collecting and preserving testimonies and evidence since March 23, 2016 (UN Human Rights Council, Undated). Although, no fundamental rights of the people have improved.

Vietnam: American military killed a large number of civilians in a remote Vietnamese hamlet in November 1969 and in another massacre 13 unarmed Vietnamese women and children were killed in February of 1969 (Shapiro, May 2, 2001). The question of TRC has started to rise, but does not seem that much of pressing demand.

A number of Gulf countries such as Egypt, Jordan, Iran, Iraq, Lebanon, Libya and Kuwait faces huge national and international pressure to establish the Truth Commission on the course to investigate excessive use of power, a grave human rights violations and or abuses in the past.

Marc Michael argues that Egypt needs to draw on lessons from Africa and beyond on transitional justice. Egypt should realize onits very own to set up a Truth and Reconciliation Commission of past wrongdoings (February 12, 2011). Iran Tribunal was formed in 2007 by multiple victims and their families and the formation was aided by many renowned lawyers and Human Rights activists (Bowcott, October 18, 2012). The Iranian Truth Commission was constituted to investigative as a part of the Tribunal by the Amnesty International 
in London during June 18-22, 2012. It collected about 100 cases of statements and testimonies mostly from witnesses or survivors having the extrajudicially killings, disappearances and among others (Amnesty International, December 4, 2018). Concentrating on the Iraq war and serious human rights violations and/or abuses, international media asked Iraq to form a Truth Commission (Payne, February 17, 2011), but in vain for its establishment.

Ever since the armed conflict in Lebanon broke out in the mid-1970s, the families of missing and disappeared persons demanded securing the right to know the truth and the right to an effective investigation (Noureddine, March 12, 2018). On the course of victims' human rights violations and/or abuses in Libya, there have been high demands on realizing their right to know the truth, accountability, receive adequate reparations and peaceful coexistence between the communities (LFJL, Undated). Inter-and-infra armed conflicts in the Gulf are very common due to the competition of super-powers to control oil and its products. Until the Gulf countries are decolonized from the super-power countries and they adopt functional liberal democracy, the formation of Truth Commissions would not be possible there. On the other hand, the trends of orthodox Muslims indoctrination needed to be changed for respect, promotion and protection of the rights to life, liberty, security and dignity of all despite race, caste, ethnicity, color, geography, region, creeds and poor-rich believing that human beings are the same: birth, blood, and death.

In the Generation-0, the notion of justice establishing the Truth Commission could not work despite huge public demands and international pressure owing to the lack of practicing liberal democratic system. Such post-conflict countries are generally holding alleged perpetrators. These regimes always have a fear that whether the TRC would document statements, testimonies and evidence against them as perpetrators. Moreover, they focus more on forgiving the perpetrators through (a blanket amnesty) declaration or incorporating into the act and forgetting the grievances, pains and sufferings of the victims and the survivors. Thus, such countries have left profound socio-cultural, emotional, and political scars on people forever.

\section{CONCLUDING REMARKS}

The Genesis of the Transitional Justice started immediately after the second WW prosecuting and punishing the leaders and soldiers in the names of Nuremberg Trial and Tokyo Tribunal. After such experiences, transitional justice has widely been practiced and it has been punishing the war crimes leaders and soldiers starting from Uganda in 1974, military juntas in Greece in 1975.

Both Nuremberg Trial and Tokyo Tribunal are regarded as milestones toward the establishment of a Permanent International Court to deal with war crimes, crimes against humanity, genocide and others. The ICC examined crimes of war against narcotic drugs where more than 4,000 people were killed by the police in the Philippines, but on March 13, 2018, Philippines notified the UN Secretary-General of its decision to withdraw from the treaty of the Rome Statute. In November 2016, Gambia notified its decision to withdraw from the Rome Statute, but the newly elected government annulled the decision in early 2017. Burundi withdrew from the Rome Statute effecting from October 2017. United States, Russia, Israel and Sudan have notified the UN Secretary-General for not having the state parties of the Rome Statute. China and India are critical on the Court since its beginning. Although ICC calls itself an autonomous institution, it has been a witness that the ICC is established by the backing of powerful (non-signatory) countries as a political entity to control the resources and politics of the weak and poor countries. 
In Nuremberg Trial, the American soldiers were so cruel to adopt a 'tit-for-tat' policy, even the punishment through hanging the perpetrator that took 14 to 28 minutes. The Americans who hold power, politics and privileges are experts for conspiracy theory. The arrogance and threat-o-cracy are the identities of the US Government including Trump-ism which being existed for a long, Generations to Generations. The Transitional Justice Generations are highly influenced by the US Government's favoritism, nepotism, and sycophancy policies which are being germinated as satellite strategies across the world. To minimize the demands of the former insurgent CPN (Maoist) Party during Maoist Army integration in Nepal, the former insurgent supremo Prachanda was threatened informally by the powerful elites including USA to prosecute and punish him establishing Transitional Justice in Nepal.

In the case of Nepal, a few victims' leaders or representatives, who are empowered by NonGovernment Organizations and often manipulated by the alleged perpetrators, try hard to defame the CIEDP and TRC Commissioners calling them incompetent and unqualified. A few victims who reside in the urban centers of the country often look upon self-opportunities including more relief and reparation supports, whereas countryside poor victims seek justice by means of finding out the 'truth', whereabouts of their loved ones alive or dead.

Transitional justice has been a long neglected history owing to anarchical-powerful roles of the perpetrators and weak, poor, docile, illiterate and silent nature of the victims and survivors. Moreover, victims, survivors and witnesses always feel insecure from the alleged perpetrators if they tell the truth to the Commission. Victims often undergo uncertainty of how such politically motivated Commission maintains the secrecy of their structural facts, statements and testimonies.

Most of the Truth Commissions formed around the world did not follow proper Census Method of investigation. And no such Commissions reached all poor victims and society at large in the countryside. However, the CIEDP of Nepal tries hard to deliver the World's Best Model on transitional justice mechanism. Here are a few reasons how the CIEDP ensures one of the best models.

First, the CIEDP has collected complaints of all on enforced disappearances from Local Peace Committees and its own Head Office. The complaint registration was opened in three phases for six months. Second, it has adopted preliminary action, preliminary investigation and detailed investigations of all creating individual file of each and every complaint registration. Third, the detailed investigation follows networking tracking methods or snow-ball techniques. The detailed investigation heads to several steps: collecting additional information-statements (for what purpose, where, when, why, how and who involved or happened) on disappeared 'loved-one' as storytelling (telling the truth stories) from the complainants or key informants. Besides, the CIEDP filled-up Ante-Mortem Data Collection and Reparation forms, and collected the statements from the concerned witnesses as well on the leadership of the Commissioners following Direct Participant Observation. The Research Team is deployed to all district headquarters and then complainant houses in the remote villages. The CIEDP ensures Census Method for these purposes. Fourth, it provides an ample opportunity of interrogation of all alleged perpetrators: 'right to information', 'right to know' 'right to an effective investigation' and 'right to defend' for innocence. Fifth, closed-opened and issue-wise public hearings are conducted. Sixth, emblematic exhumation including excavation will be conducted. DNAs matching will also be carried out extracting DNA test of the degenerated remains and collecting reference samples from the concerned family members to identify the concerned family of the disappeared person. Lastly, the final report with full recommendations including reparation and non-recurrence will be submitted to the Prime Minister of Nepal. And the complete name 
lists of the perpetrators will be handed down to the Attorney General to file the case at the Special Court to ensure accountability and justice to the victims, survivors, and society at large. Of late, the Transitional Justice has drawn the international attention which greatly influences the Generations of all ages. None of the concerned institutions and state-leaders (often called as perpetrators) feels accountable to ensure justice to the victims. It has been witnessed that world's Transitional Justice ironically ensures freedom to the perpetrators further limiting justice to the poor victims in all Generations (Pathak, 2016).

The major learning of the TJ Generation is that TJ has been a political subject matter rather than a justice mechanism targeted at the victims and society at large. Almost the same powerful perpetrators continuously remain in State-power even in the post-conflict situation that further limits the rights to truth and justice. Such perpetrators are responsible for dismantling the structural statements, testimonies and evidence ordering in all the chain-andcommand of security agencies regarding their proofs of involvement in crimes in the past. Moreover, the policy-makers (perpetrators) often tend to prosecute and punish the junior ones only not to spoil their reputation amongst the civilians. They further ask the concerned victims and society to forget the past crimes and forgive them as those wrongdoings happened for the sake of specific purpose - usually, 'social change'. Therefore, only a small number of victims have received justice, to date, in the post-conflict countries across the globe. Thus, the Transitional Justice sets-up a new world order system that gradually secedes into multi-polar regions because of identity-based interests and its actions accordingly. Therefore, unaddressing the TJ shall invite communal violence in future. It means violence begets more fearful violence.

\section{References}

10 The Rwanda Genocide and Its Aftermath. Retrieved August 14, 2018, from http://www.unhcr.org/enmy/3ebf9bb60.pdf.

A/72/349. (2017, September 29). Report of the International Criminal Court: Note by the Secretary-General. New York: UN General Assembly.

A/HRC/17/28/Add.2. (2011, May 9). Report of the Special Rapporteur on extrajudicial, summary or arbitrary executions, Philip Alston. (70th ed.). Gevena: Human Rights Council.

A/HRC/22/45/Add.2. (2013, February 26). Report of the Working Group on Enforced or Involuntary Disappearances on its mission to Pakistan. UN General Assembly.

A/RES/57/228 B. (2003, March 22). Resolution adopted by the General Assembly: 57/228. Khmer Rouge trials. United Nations.

Acirokop, P. (2012). A truth commission for Uganda: Opportunities and challenges. African Human Rights Law Journal, 12.

Adigun, M. (2017, December 14). The International Criminal Court and Nigeria: Implementing the Complementarity Principles of the Rome Statute. New York: Routledge

AFP-Jiji. (2016, December 22). Peruvian prison "slowly killing" ex-President Fujimori. The Japanese Times. Retrieved May 2, 2017, from http://www.japantimes.co.jp/news/2016/12/22/world/peruvian-prison-slowlykilling-ex-presidentfujimori/

Agency France Presse. (2018, September 11). US threatens to arrest and sanction ICC Judges. The Himalayan Times. Kathmandu.

Agren, D. (2018, December 3). Mexico's new president creates truth commission to investigate 43 missing students. The Guardian. London.

Ainley, K. (2014). Transitional justice in Cambodia: the coincidence of power and principle. Transitional justice in the Asia-Pacific. Cambridge University Press.

Al Bashir Case. Retrieved October 23, 2018, from www.icc-cpi.int/darfur/albashir. 
Aljazeera. (February 6, 2019). Ivory Coast's ex-president Laurent Gbagbo released to Belgium. Retrieved May 30, 2019, from https://www.aljazeera.com/news/2019/02/ivory-coast-president-laurent-gbagbo-released-belgium190206061604107.html.

Alleged crimes (non-exhaustive list). Retrieved September 7, 2018, from https://www.icc-cpi.int/mali/almahdi/pages/alleged-crimes.aspx.

Allen, R. B. (1999). Slaves, Freedman, and Indentured Laborers in Colonial Mauritius. Cambridge University Press.

Allier, E. (2006, October). The Peace Commission: A Consensus on the Recent Past in Uruguay? European Review of Latin American and Caribbean Studies, 81.

Allison, D. \& Reid, S. (2015, March). Overcoming Violence and Impunity: Human Rights Challenges in Honduras. House of Commons.

Amara, T. (2019, March 27). Tunisia 'Truth' Commission says many rights abuse cases yet to reach court. Reuters.

Ambos, K. (2011). The Crime of Aggression After Kampala. German Yearbook of International Law 53.

Ambruster, H. W. (1947). Treason's Peace. Beechhurst Press.

Amnesty International. (1991, October). Amnesty International's Concerns in Ecuador. London.

Amnesty International. (1992, May). "Disappearances" in Honduras: A wall of silence and indifference. London.

Amnesty International. (1998). Amnesty International Report 1998 - Honduras. London.

Amnesty International. (1998). Honduras: Still awaiting for Justice. London.

Amnesty International. (2000, December). Nigeria: Time for Justice and Accountability. London.

Amnesty International. (2000, December). Nigeria: Time for Justice and Accountability. London.

Amnesty International. (2007, June 11). Truth, justice and reparation Establishing an effective truth commission. London.

Amnesty International. (2018). Willingly Unable: ICC Preliminary Examination and Nigeria's Failure to Address Impunity for International Crimes. London.

Amnesty International. (2018, December 4). Iran committing crimes against humanity by concealing fate of thousands of slaughtered political dissidents. London.

Amnesty International. (2019, February 12). South Sudan: The Human Rights Council should fully renew the mandate of the Commission on Human Rights in South Sudan. London.

Amnesty International. (2019, January 7). Gambia: Truth Commission hearings an important step towards justice and reparations. London.

Amnesty International. (2019, March 25). Tunisia: Truth Commission findings must lead to justice for thousands of victims of human rights violations. London.

Amnesty International. (Undated). Time for Justice for Senegal. London.

Aning, K. \& Jaye, T. (2011, April). Liberia: A Briefing Paper on the TRC Report. Occasional Paper. No. 33. Kofi Annan International Peace Peacekeeping Training Center.

Argentine National Commission on Disappeared. (1986). The Report of the Argentine National Commission on the Disappeared. London and Boston: Faber and Faber.

Arnould, V. (2007, May 30). Amnesty, Peace and Reconciliation in Algeria. Conflict, Security \& Development. 7 (2).

Arsanjani, M. H. (1999, January). Developments in International Criminal Law: The Rome Statute of the International Criminal Court. American Journal of International Law. Volume 93.

Asemota, B. (October 16, 2018). President Barrow launches TRRC. The Point. The Gambia.

Asia Justice and Rights. (Undated). Indonesia. Retrieved on May 21, 2019, from https://asia-ajar.org/indonesia/. Associated Press. (2017, October 7). Burundi threatens to withdraw from international criminal court. Bujumbura, B92. (2015, March 17). 11 years since "March Pogrom" of Serbs in Kosovo. Zemun.

Ball, P. (1998, April 15). Who Did What to Whom: Planning and Implementing a Large Scale Human Rights Data Project? Lecture at Columbia University. 
Bandi, G. P. S. (2013). "Sangkramankalin Nyaya: Aba Dharana, Upaya, Samrachana Tatha Nepalma Yesko Prayog (Transitional Justice: Concept, Solution, Structure and Practice in Nepal)". Transitional Justice in Nepal. Transitional Justice Law Committee and Nepal Bar Association.

Bangladesh. (1973, July 20). International Crimes (Tribunals) Act, 1973. Dhaka.

Basic, S. (Undated). Bosnian Society on the Path to Justice, Truth and Reconciliation. Berghof Foundation.

Bauer, Y. (1978). The Holocaust in Historical Perspectives. Canberra: Australia National University Press.

BBC News. (2010, October 19). ICC to proceed with Bemba war crimes trial. London.

BBC News. (2011, December 16). ICC dismiss Rwanda rebel Callixte Mbarushimana charges. London.

BBC News. (2015, October 16). Profile: Abdullah al-Senussi. London.

BBC News. (2017, February 1). African Union backs mass withdrawal from ICC. London.

BBC News. (2018, August 7). Ivory Coast ex-first lady Simone Gbagbo granted amnesty. London.

BBC. (2009, March 4). Warrant issued for Sudan's leader. Retrieved August 15, 2018, from

http://news.bbc.co.uk/2/hi/africa/7923102.stm.

BBC. (2009, May 18). Darfur rebel appears before ICC. London.

BBC. (2010, April 28). Russia publishes Katyn massacre archives. London.

BBC. (2016, May 30). Hissene Habre: Chad's ex-ruler convicted of crimes against humanity. London.

BBC. (2017, December 25). Fujimori: Peru president's pardon for ex-leader draws protests. London.

BBC. (2018, August 1). Democratic Republic of Congo Profile Timeline. London.

BBC. (2018, May 7). Nicaragua sets up commission after protest deaths. London.

BBC. (April 11, 2019). Omar al-Bashir ousted: How Sudan got here. London.

BBC. December 16, 2004. Russian to release massacre files. London.

Beigbeder, Y. (2011). Special Panels for Serious Crimes in East Timor - Now Timor- Leste. International Criminal Tribunal.

Beitler III \& Edward, J. (2013). Remaking Transitional Justice in the United States: The Rhetorical Authorization of the Greensboro Truth and Reconciliation Commission. New York: Springer Science \& Business Media.

Benedetti, F. (1996). Haiti's Truth and Justice Commission. Human Rights. Brief 3, 3. Washington.

Bhim, M. (2007). Issues: Chapter 10 - The impact of the Reconciliation, Tolerance and Unity Bill on the 2006 election. In (eds) Firth, S. Fraenkel, J. 2007, From Election to Coup in Fiji - The 2006 campaign and its aftermath. ANU E-Press, Asia Pacific Press and IPS Publications.

Bobowik, M., Arnoso, M. \& Beristain, C. (2015, January). The Commission of Truth and Justice in Paraguay: emotional experience in commemoration rituals and the perceived efficacy of the commission. ResearchGate.

Boraine, A. (2001). A Country Unmasked: Inside South Africa's Truth and Reconciliation Commission. Bulletin of the School of Oriental and African Studies, 64(3).

Bowcott, O. (2012, October 18). Tribunal to investigate 1980s massacre of political prisoners in Iran. The Guardian.

Breyer, S. (1996, November). "Crime against Humanity: Nuremberg 1946". New York University Law Review. Volume 71, No. 5.

Brocchetto, M. March 10, 2015. Ivory Coast's Simone Gbagbo sentenced to 20 years in prison. CNN. Georgia.

Brownlie, I. (1963). International law and the Use of Force by States. Oxford University Press.

Buergenthal, T. (1994, October). The United Nations Truth Commission for El Salvador. Vanderbilt Journal of Transnational Law, 27(3).

Burnett, V. (2008, November 13). Rights lawyers file Spanish court case on El Salvador killings. International Herald Tribune.

Business Recorder. (2008, July 31). Bangladesh sets up corruption 'truth commission'. Dhaka.

Butow, R. J. C. (1954). Japan's Decision to Surrender. Stanford University Press. 
C.N.121.2017.Treaties-XVIII.10. (2017, March 7). South Africa: Withdrawal of Notification of Withdrawal. New York: United Nations.

C.N.138.2018. 2019, March 17. Philippines: Withdrawal. New York: United Nations.

C.N.786.2016. 2017, October 19. South Africa: Withdrawal. New York: United Nations.

C.N.805.2016. 2018, October 27. Burundi: Withdrawal. New York: United Nations.

C.N.862.2016.Treaties-XVIII.10. November 11, 2016. Gambia Withdrawal. New York: United Nations.

Cain, N.T. (2013, May 1). Final Report of the Solomon Islands Truth \& Reconciliation Commission unofficially released. The Australian National University.

Carranza, R. (2018, November 9). Shaping a Transitional Justice Strategy for Armenia: A Conversation with Anna Myriam Roccatello and Ruben Carranza. New York: International Center for Transitional Justice.

Carver, R. (1989). Zimbabwe: A break with the past?: Human rights and political unity. New York: African Watch Committee.

Case File No. 002/19-09-2007/ECCC/TC. (2018, November 18). Trial Chamber: Summary of Judgment Case 002/02. Phnom-Penh.

Case Information Sheet. (2017, August 17). Situation in the Republic of Mali: The Prosecutor v. Ahmad Al Faqi Al Mahdi. Hague: International Criminal Court.

Cassese, A. (2013). Cassese's International Criminal Law (3rd ed.). Oxford University Press.

CAVR Chega! Report. (2015). The Report of the Timor-Leste Commission for Reception, Truth, and Reconciliation. KPG Gramedia.

CBC News. (2018, November 24). Tearful Justin Trudeau apologizes to N.L. residential school survivors. Toronto.

Center for Constitutional Rights. (Undated). The Struggle for Truth in Honduras: The Truth and Reconciliation Commission vs. the True Commission. New York.

Charles, J. H. \& Chang, J. S. (2008, August 4). AP IMPACT: Seoul probes civilian 'massacres' by US. Truth and Reconciliation Commission, Republic of Korea.

Citizens' Truth Commission. (2018, December 18). Report related to Citizen's commission on obtaining comments and suggestions of the citizens in various fields to minimize racialism in Sri Lanka. Kandy District Inter Religious Committee.

CM Communications. (2019, February 25). Designated President of the Ethiopian Truth and Reconciliation Commission. Congregation of the Mission.

Coalition for the International Criminal Court. Retrieved September 14, 2018, from Available in http://www.coalitionfortheicc.org/country/nigeria.

COHA. (2011, November 1). Forced Disappearances in Colombia. Washington.

Cohn, G., \& Ginger, T. (1995, June 11). When a wave of torture and murder staggered a small U.S. ally, truth was a casualty. The Baltimore Sun. Baltimore Sun Media Group Publication.

Colombo Gazette. (2018February 27). Ampara tense following attack on shop and mosque. Retrieved April 25, 2018, from http://colombogazette.com/2018/02/27/ampara-tense-following-attack-on-shop-and-mosque/.

Commission for Historical Clarification. Retrieved April 16, 2017, from

https://www.usip.org/publications/1997/02/truth-commission-guatemala.

Commission for Peace. Retrieved April 13, 2017, from https://www.usip.org/publications/2000/08/truthcommission-uruguay

Commission of Inquiry into the Disappearance of People I. Retrieved July 13, 2018, from www.usip.org/publications/1974/06/truth-commission-uganda-74.

Commission of Inquiry. (1992, May 7). Chad: Report of the Commission of Inquiry into the Crimes and Misappropriations Committed by Ex-President Habré, His Accomplices and/or Accessories. Retrieved May 11, 2019 https://www.usip.org/sites/default/files/file/resources/collections/commissions/Chad-Report.pdf.

Commission of Investigation on Enforced Disappeared Persons. Retrieved May 17, 2017, from http://www.ciedp.gov.np/ne/.

Commission on the Truth for El Salvador. Retrieved April 15, 2017, from https://www.usip.org/publications/1992/07/truth-commission-el-salvador. 
Confidential. (2018, May 7). National Assembly Appoints Truth Commission. Retrieved May 6, 2019, from https://confidencial.com.ni/national-assembly-appoints-truth-commission/.

Conot, R. E. (1983). Justice at Nuremberg. New York: Harper and Row.

Corntassel, J. \& Holder, C. (2008). "Who's sorry now? Government apologies, truth commissions, and Indigenous self-determination in Australia, Canada, Guatemala, and Peru. Human Rights Review, 9 (4).

Crenzel, E. (2008, July). "Argentina's National Commission on the Disappearance of Persons: Contributions to Transitional Justice". International Journal of Transitional Justice, 2(2).

Croucher, R., Houssart, M., \& Michel, D. (Undated). The Mauritian Truth and Justice Commission: Legitimacy, political negotiation and the consequences of slavery. Retrieved May 12, 2019, from https://core.ac.uk/download/pdf/19206132.pdf.

Cueva, E. G. (2004). The Contribution of the Peruvian Truth and Reconciliation Commission to Prosecutions. Truth Commissions And Courts. Dordrecht: Springer.

Custódio, R. (2015, April 27). Final Report of the National Truth Commission: What now, Brazil? CONECTA. Czech Republic Police. (2008, June 1). The Office for the Documentation and the Investigation of the Crimes of Communism Police of the Czech Republic. Prague.

Czitrom, C. G. (2002, January). Truth Commissions: An Uncertain Path. CODEPU-Chile and APT-Switzerland.

Czyzewski, K. (2011). The truth and reconciliation commission of Canada: Insights into the goal of transformative education. The International Indigenous Policy Journal, 2(3), 4.

Dabanga. (2013, October 4). ICC Darfur Chamber terminates proceeding against Saleh Jerbo. Retrieved August 16, 2018, from www.dabangasudan.org/en/all-news/article/icc-darfur-chamber-terminates-proceedings-againstsaleh-jerbo.

Dean J. Alton Hosch: More About the IMTFE. (Undated). Alexander Campbell King Law Library and School of Law of University of Georgia.

Declaration recognizing the Jurisdiction of the ICC. January 21, 2009. Palestine National Authority: Minister for Justice. Hague.

Dehaas, J. (2015, November 3). "'A new beginning' National Centre for Truth and Reconciliation opens in Winnipeg”. CTVNews.ca.

Democratic Republic of the Congo. Retrieved August 19, 2018, from https://www.icc-cpi.int/drc.

Democratic Republic of the Congo. Retrieved September 25, 2018, from https://www.icc-cpi.int/drc.

Department of State Bulletin. (1945, October 21). Summary of the indictment. Washington.

Dibbert, T. (2017, September 19). 'Putting Sri Lanka's Office of Missing Persons in Perspective'. The Diplomat.

Dicklitch, S. \& Malik, A. (2010, January 9). Justice, Human Rights, and Reconciliation in Postconflict Cambodia. Human Rights Review, 11 (4).

Dobell, L. (1997, June). Silence in context: truth and/or reconciliation in Namibia. Journal of Southern African Studies. Volume 23, Number 2.

Dolidze, A. \& Wall, T. D. (2012, December 12). A Truth Commission for Georgia. Carnegie Europe.

Domegni, M. (2016, July 31). Togo still waiting for democratic transition. Justice Info Net.

Dower, J. W. (2000, June). Embracing Defeat: Japan in the Wake of World War II. New York: W.W. Norton.

Dragovic-Soso, J. (2016). History of a Failure: Attempts to Create a National Truth and Reconciliation Commission in Bosnia and Herzegovina, 1997-2006. The International Journal of Transitional Justice, 10(2).

Dwyer, C. (2018, June 8). Former Congolese Vice President Cleared of War Crimes Convention on Appeal. Retrieved September 18, 2018, from https://www.npr.org/2018/06/08/618273154/former-congolese-vice-presidentcleared-of-war-crimes-conviction-on-appeal.

EAAF 2002 Annual Report. (2002). Uruguay. Retrieved May 17, 2019, from https://eaaf.typepad.com/pdf/2002/15Uruguay.pdf.

EAAF. (2002). Uruguay: Annual Report. Retrieved May 29, 2019, from

https://eaaf.typepad.com/pdf/2002/15Uruguay.pdf

Eastern Congo Initiative. (Undated). History of the Conflict. Minneapolis. 
ECCC at a Glance. (2014, April). Phnom Penh.

Editor. 2001 and 2007. Who's who in Nazi Germany? London: Declassified and Released by Central Intelligence Agency Sources.

Elagab, O. Y. (2008, September). The Darfur Situation and the ICC: An Appraisal. Journal of Politics and Law. 1 (3).

Escritt, T. (2018, December 18). In second verdict, war crimes court acquits Congolese. Reuters.

Ethirajan, A. (2011, May 16). Bangladesh truth commission is declared 'illegal'. London: BBC

EU Reporter Correspondence. (2015, April 17). Analysis: The UN in Kosovo-success or failure? EU reporter world.

European Journal of International Law. (2010, November). Imperfect Justice at Nuremberg and Tokyo. Volume 21, Issue 4.

Executive Order No. 8. (1986, March 18). Creating the Presidential Committee on Human Rights. Manila.

Farah, D. (2000, November 27). Chad's Torture Victims Pursue Habre in Court. The Washington Post.

Fareed, R. (2017, November 3). India ordered to probe 2,080 mass graves in Kashmir. Aljazeera.

Fears, D. (2005, March 6). Seeking Closure on 'Greensboro Massacre'. Washington Post.

Filho, P. (2012, February). Truth Commission in Brazil: Individualizing Amnesty, Revealing the Truth. Yale Review of International Studies.

Fischer, M. (Ed., 2007). Peacebuilding and Civil Society in Bosnia-Herzegovina: Ten Years after Dayton. Berghof Foundation of Conflict Studies.

Flagpole Magazine. (2002, July 17). The Trial of the Century-and of All Time, part two. Georgia.

Flores, C. (2017, September 3). Searching DNA: Identifying the Disappeared in Colombia. Al Jazeera.

Fombad, C. (2017, February). Update: Transitional Justice in Africa- The Experience with Truth Commissions.

GlobaLex, Hauser Global Law School Program \& New York University School of Law.

Forsythe, D. P. (Ed., 2009). Encyclopedia of Human Rights, 5. Oxford University Press.

Fraser, David. (2017). (De)Constructing the Nazi State: Criminal Organizations and the Constitutional Theory of the International Military Tribunal. 39 Loyala. Loyola of Los Angeles International and Comparative Law Review 117.

Freeman, M. (2004, October). Serbia and Montenegro: Selected Development in Transitional Justice. International Center for Transitional Justice.

Friendship Office of the Americas. (November 1, 2009). Accord for National Reconciliation and the Strengthening of Democracy in Honduras. Greenbelt.

Gaiba, F. (1998). The origins of simultaneous interpretation: the Nuremberg Trial. Ottawa: Ottawa University Press. German Instrument of Surrender. (1945, May 8). Act of Military Surrender. Germany.

Gettleman, J. (January 31, 2008). Official Sees Kenyan Ethnic Cleansing. The New York Times.

Ghana National Reconciliation Commission. (2004). Final Report. Accra: Ghana Publishing Corporation.

Global Legal Monitor. (July 21, 2015). African Union; Chad; Senegal: Former Chad Dictator Hissene Habre's Trial Opens in Dakar. Library of Congress.

Global Rights Compliance. (2016, December). Ukraine and the International Criminal Court. United Kingdom.

Goldensohn, L. N. (2004). The Nuremberg Interviews: Conversations with the Defendants and Witnesses. New

York: Alfred A. Knopf.

Gonzalez, E. (2011, December 6). Brazil Shatters Its Wall of Silence on the Past. New York: International Center for Transitional Justice.

Goodhart, A. L. April 1946. "The Legality of the Nuremberg Trials". Juridical Review. Scotland

Greensboro Truth and Reconciliation Commission. Retrieved April 26, 2019, from

http://www.greensborotrc.org/exec_summary.pdf.

Greiff, P. de. (2006). The Handbook of Reparations. Oxford University Press.

Gunson, P. (2006, August 17). General Alfredo Stroessner-Dictator who mastered the fixing of elections and made Paraguay a smugglers' paradise. The Guardian. 
Hand, M. (2004, November 18). The Greensboro Massacre. Press Action.

Hayner, P. (1994). Fifteen Truth Commissions-1974 to 1994: A Comparative Study. Human Rights Quarterly, 16(4). Hayner, P. B. (2002). Unspeakable Truths: Facing the Challenge of Truth Commissions. New York: Routledge.

Hayner, P. B. (2011). Unspeakable Truths: Transitional Justice and Challenge of Truth Commissions. New York and London: Routledge.

Henkel, M. (2011). Memoriam Nuernberger Prozesse, exhibition catalogue (German), Nuremberg. Museen der Stadt Nuernberg.

Hibbitts, B. (2007, May 6). Ecuador Launches Truth Commission to Investigate Past Rights Abuses. Jurist.

Hiru News. (2018, March 5). Teldeniya and Digana Tense. Retrieved April 23, 2019, from

http://www.hirunews.lk/185189/kandy-tense-as-mob-attacks-spread-to-digana.

History of the Conflict. Retrieved August 18, 2018, from http://www.easterncongo.org/about-drc/history-of-theconflict.

History. Retrieved January 15, 2019, from www.history.com/topics/world-war-ii/nuremberg-trials.

Human Rights Council. (2016, June 8). UN Inquiry finds crimes against humanity in Eritrea. Geneva.

Human Rights Office of the High Commissioner. (2016, June 1). Commission of Inquiry on Human Rights in Eritrea. Geneva.

Human Rights Watch Report. (2014). To Consolidate This Peace of Ours: A Human Rights Agenda for Côte d'Ivoire. New York: Human Rights Watch.

Human Rights Watch. (1992, December). Bolivia: Almost Nine Years and Still No Verdict in the "Trials of Responsibility". New York.

Human Rights Watch. (1995). "Germany for Germans" Xenophobia and Racism Violence in Germany. Helsinky.

Human Rights Watch. (1995, April). “Germany for Germans”: Xenophobia and Racist Violence in Germany. New York.

Human Rights Watch. (2004, July 24). Kosovo: Failure of NATO, U.N. to Protect Minorities. New York.

Human Rights Watch. (2005, July). Chad: The Victims of Hissène Habré Still Awaiting Justice. Vol. 17, No. 10(A).

Human Rights Watch. (2005, November). Morocco's Truth Commission: Honoring Past Victims during an Uncertain Present. Vol. 17, No. 11(E).

Human Rights Watch. (2008). World Report 2008: Indonesia-Events of 2007. New York.

Human Rights Watch. (2009, July 7). Selling Justice Short: Why Accountability Matters for Peace. Washington.

Human Rights Watch. (2011, January). Kenya and the International Criminal Court. New York.

Human Rights Watch. (2018, April 27). Human Rights Situation in Eretria. New York.

Human Rights Watch. (2019, April 8). Ethiopia: Abiy's First Year as Prime Minister, Review of Accountability and Justice. New York.

Human Rights Watch. (2019, February 22). Central African Republic: Justice Vital to Peace. Washington.

Human Rights Watch. (2019, March 15). US Threatens International Criminal Court. New York.

Human Rights Watch. October 27, 2016. Burundi: ICC Withdrawal Major Loss to the Victims. New York.

ICC. (2008, February 8). Statement of the Prosecutor of the International Criminal Court, Mrs Fatou Bensouda, on opening Preliminary Examinations into the situations in the Philippines and in Venezuela. Hague.

ICC. (2012, April 3). Situation in Palestine. Hague.

ICC. (2014, June). Situation in the Republic of Korea: Article 5 Report. Hague.

ICC. (2014, September 2). Statement of the Prosecutor of the International Criminal Court, Fatou Bensouda: 'The Public Deserves to know the Truth about the ICC's Jurisdiction over Palestine'. Hague.

ICC. (2014, September 24). Situation in the Central African Republic II: Executive Summary. Hague.

ICC. (2015, November 12). Report on Preliminary Examination Activities 2015. Hague. 
ICC. (2015, October 28). Statement of the Prosecutor of the International Criminal Court, Fatou Bensouda, on the conclusion of the preliminary examination into the situation in Honduras. Hague.

ICC. (2017). Report on Preliminary Examination Activities (2017) - Gabon. Hague.

ICC. (2017, December 4). Report on Preliminary Examination Activities 2017. Hague.

ICC. (2018, May 9). Fifteenth Report of the Prosecutor of the International Criminal Court to the United Nations Security Council Pursuant to UNSCR 1970 (2011). Hague.

ICC. November 2012. Report on Preliminary Examination Activities 2012. Hague.

ICC-01/05-01/13. (2018, September 17). Situation in the Central African Republic: In the Case of the Prosecutor v. Jean-Pierre Bemba Gombo, Aime Kilolo Musamba, Jean-Jacques Mangenda Kabongo, Fidele Babala Wandu and Narsisse Arido. Hague.

ICC-01/05-01/13-749. (2014, November 11). Pre-Trial Chamber II. Hague.

ICC-01/09-01/11. (2012, February 14). Situation in the Republic of Kenya, In the Case of Prosecutor v. William Samoei Ruto, Henry Kiprono Kosgey and Joshua Arap Sang. Hague.

ICC-01/09-01/11. (2016, April 5). Ruto and Sang Case. Hague.

ICC-01/09-01/13. (2013, October 2). Barasa Case. Hague.

ICC-01/09-01/15. (2015, March 10). Pre-Trial Chambers II. Hague.

ICC-01/09-01/15. (2015, September 10). Situation in the Republic of Kenya. Hague.

ICC-01/09-02/11. (2015, March 13). Case Information Sheet, Situation in the Republic of Kenya: The Prosecutor v. Uhuru Muigai Kenyatta. Hague.

ICC-01/12-01/15-171. (2016, September 27). Situation in the Republic of Mali: In the Case of the Prosecutor v. Ahmad Al Faqi Mahdi. Hague.

ICC-01/14-02. (2019, January 24). Situation in the Central African Republic II. Hague.

ICC-01/15. Situation in Georgia. Hague.

ICC-02/04. Situation in Uganda. Retrieved September 2, 2018, from https://www.icc-cpi.int/uganda.

ICC-02/04-01/05. Kony et al. Case. Retrieved September 2, 2018, from https://www.icc-cpi.int/uganda/kony.

ICC-02/04-01/05-270. (2008, February 29). Annex: Public Redacted Version. Hague.

ICC-02/05-01/09. (2017, February 28). Pre-Trial Chamber II: Situation in Darfur, Sudan in the Case of the Prosecutor V. Omar Hassan Almad Al Bashir. Hague.

ICC-02/05-01/12-21. (2013, November 13). Situation in Darfur, Sudan: In the Case of the Prosecutor v. Abdel Raheem Muhammad Hussein. Hague.

ICC-02/05-02/09. The Prosecutor v. Bahar Idriss Abu Garda. Retrieved August 16, 2018, from https://www.icccpi.int/darfur/abugarda.

ICC-02/11. Situation in the Republic of Côte d'Ivoire. Retrieved September 10, 2018, from https://www.icccpi.int/cdi.

ICC-02/11-01/15. Gbagbo and Blé Goudé Case. Retrieved August 29, 2018, from https://www.icccpi.int/cdi/gbagbo-goude.

ICC-01/09-02/11. (2015, March 13). Situation in the Republic of Kenya: In the Case of the Prosecutor v. Uhuru Muigai Kenyatta. Trial Chamber V(B). Hague.

ICC-CPI-20180704-MA228. (2018, July 4). Ntaganda case: Closing statements to take place on 28-30 August 2018. Hague.

ICC-PIDS-CIS-CAR-01-020/18_Eng. (2018, June 8). Case Information Sheet, Situation in the Central African Republic: The Prosecutor v. Jean-Pierre Bemba Gombo. Hague.

ICC-PIDS-CIS-CAR-02-012/17_Eng. (2017, March). Case Information Sheet, Situation in the Central African Republic: The Prosecutor v. Jean-Pierre Bemba Gombo, Aimé Kilolo Musamba, Jean-Jacques Mangenda Kabongo, Fidèle Babala Wandu and Narcisse Arido. Hague.

ICC-PIDS-CIS-CI-02-006/18_Eng. (2018, April). Case Information Sheet, Situation in Côte d'Ivoire The Prosecutor v. Simone Gbagbo. Hague. 
ICC-PIDS-CIS-CI-04-03/16_Eng. (2016, January). Case Information Sheet, Situation in Côte d'Ivoire The Prosecutor v. Laurent Gbagbo and Charles Blé Goudé. Hague.

ICC-PIDS-CIS-DRC-01-016/17_Eng. Retrieved October 17, 2018, from, https://www.icccpi.int/CaseInformationSheets/LubangaEng.pdf.

ICC-PIDS-CIS-DRC-02-011/15_Eng. (2017, January). Case Information Sheet, Situation in the Democratic Republic of the Congo: The Prosecutor v. Bosco Ntaganda. Hague.

ICC-PIDS-CIS-DRC-03-014/18_Eng. (2018, March 20). Case Information Sheet, Situation in the DR Congo on The Prosecutor v. Germain Katanga. Hague.

ICC-PIDS-CIS-DRC-05-006/18_Eng. (2018, April). Case Information Sheet, Situation in the Democratic Republic of the Congo: The Prosecutor v. Sylvestre Mudacumura. Hague.

ICC-PIDS-CIS-KEN-01-012/14_Eng. (2016, April 16). Case Information Sheet, Situation in the Republic of Kenya: The Prosecutor v. William Samoei Ruto and Joshua Arap Sang. Hague.

ICC-PIDS-CIS-KEN-02-014/15_Eng. (2015, March 31). Case Information Sheet, Situation in the Republic of Kenya The Prosecutor v. Uhuru Muigai Kenyatta. Hague.

ICC-PIDS-CIS-LIB-01-013/18_Eng. (2018, August). Case Information Sheet, Situation in Libya: The Prosecutor v. Saif Al-Islam Gaddafi. Hague.

ICC-PIDS-CIS-LIB-02-002/18_Eng. (2018, April). Case Information Sheet, Situation in Libya: The Prosecutor v. AlTuhamy Mohamed Khaled. Hague.

ICC-PIDS-CIS-MAL-01-08/16_Eng. (2018, March 20). Case Information Sheet, Situation in the Republic of Mali: The Prosecutor v. Ahmad Al Faqi Al Mahdi. Hague.

ICC-PIDS-CIS-MAL-02-002/18_Eng. (2018, June). Case Information Sheet, Situation in the Republic of Mali: The Prosecutor v. Al Hassan Ag Abdoul Aziz Ag Mohamed Ag Mahmoud. Hague.

ICC-PIDS-CIS-SUD-001-005/18_Eng. (2018, April). Case Information Sheet, Situation in Darfur, Sudan: Harun”) and Ali Muhammad Ali Abd-Al-Rahman ("Ali Kushayb"). Hague.

ICC-PIDS-CIS-SUD-02-006/18_Eng. (2018, April). Case Information Sheet, Situation in Darfur: Sudan The Prosecutor v. Omar Hassan Ahmad Al Bashir. Hague.

ICC-PIDS-CIS-SUD-04-006/15_Eng. (2015, March 23). Case Information Sheet, Situation in Darfur, Sudan: The Prosecutor v. Abdallah Banda Abakaer Nourain. Hague.

ICC-PIDS-CIS-SUD-04-008/18_Eng. (2018, July). Case Information Sheet, Situation in Darfur, Sudan: The Prosecutor v. Abdallah Banda Abakaer Nourain. Hague.

ICC-PIDS-CIS-SUD-05-004/18_Eng. (2018, April). Case Information Sheet, Situation in Darfur, Sudan The Prosecutor v. Abdel Raheem Muhammad Hussein. Hague.

ICC-PIDS-CIS-UGA-001-006/18_Eng. (2018, April). Case Information Sheet, Situation in Uganda: $h$ Kony and Vincent Otti. Hague.

ICC-PIDS-CIS-UGA-02-013/18_Eng. (2018, June). Case Information Sheet, Situation in Uganda: The Prosecutor v. Dominic Ongwen. Hague.

ICC-PIDS-TCT-01-090/18_Eng. (2018, June 13). The Court Today. Hague.

ICC-PIDS-TCT-01-090/18_Eng. The Court Today. Retrieved September 25, 2018, from https://www.icccpi.int/resource-library/Documents/TheCourtTodayEng.pdf.

ICC-PIOS-CIS-LIB-03-003/18. (2018, July). Case Information Sheet, Situation in Libya: The Prosecutor v. Mahmoud Mustafa Busyf Al-Werfalli. Hague.

ICC-PTCII-01/18. (2018, March 22). Pre-Trial Chamber II. Hague.

ICRC. (2016, July 1). Lebanon: Collection of biological samples renews hope for families of the missing. Beirut.

ICRC. (2018, March 7). Germain Katanga found guilty of four counts of war crimes and one count of crime against humanity committed in Ituri, DRC. Hague.

ICTJ. (2010). Sierra Leone, UN Human Rights Council. New York.

ICTJ. (2016, November 17). Revolutionary Truth: Tunisian Victims Make History of First Night on Public Hearings for TDC. New York. 
ICTJ. (2018, May 10). Nicaragua creates Truth, Justice and Peace Commission. New York.

ICTJ. (2019, April 14). Burundi: Truth and Reconciliation Commission Calls for Women and Girls to Share their Experiences. New York.

ICTJ. (Undated). South Africa. Retrieved May 29, 2019, from https://www.ictj.org/our-work/regions-andcountries/south-africa.

Ilic, D. (2004, April 23). The Yugoslav Truth and Reconciliation Commission: Overcoming Cognative Blocks. Eurozone.

Inter-American Commission on Human Rights. (2019, February 2). IACHR Considers that the Law on Dialogue, Reconciliation and Peace in Nicaragua is Incompatible with International Standards Regarding Truth, Justice and Reparation. Reliefweb.

International Bar Association. (2005). Comments on Fiji's Promotion of Reconciliation Tolerance and Unity Bill. London.

International Center for Transitional Justice. (2005). Comment on the Bill: Establishing a Truth and Reconciliation Commission in Indonesia. New York.

International Center for Transitional Justice. (2005, August). Accountability in Argentina: 20 Years Later, Transitional Justice Maintains Momentum. New York.

International Center for Transitional Justice. (2012, September). Confronting the Past: Truth Telling and Reconciliation in Uganda. New York.

International Center for Transitional Justice. (2016, February 23). After 10 years, CAVR Report Still Resonates in Timor-Leste and Around the World. New York.

International Center for Transitional Justice. (2017 February). Accessing the Prospects for Transitional Justice in Georgia. New York.

International Center for Transitional Justice. (Undated). Sierra Leone and The Truth and Reconciliation Commission for Liberia. New York.

International Center for Transitional Justice. August 2005. Accountability in Argentina: 20 Years Later, Transitional Justice Maintains Momentum. Case Study Series. New York

International Center for Transitional Justice. Europe: Cyprus. Retrieved May 18, 2019, from https://www.ictj.org/our-work/regions-and-countries/cyprus.

International Center for Transitional Justice. South Africa. Retrieved May 13, 2019, from

https://www.ictj.org/our-work/regions-and-countries/south-africa.

International Commission on Missing Persons. (Undated). Colombia. Retrieved April 11, 2017, from https://www.icmp.int/where-we-work/the-americas/latin-america-and-the-caribbean/colombia/.

International Commission on Missing Persons. (Undated). Mexico. Retrieved May 15, 2019, from https://www.icmp.int/where-we-work/the-americas/latin-america-and-the-caribbean/mexico/.

International Criminal Court. (Undated). Retrieved May 29, 2019, from https://internationalcriminalcourtnashie.weebly.com/aims-and-objectives.html

International Criminal Court. (Undated). Understanding the International Criminal Court. The Hague.

International Criminal Court. Retrieved August 13, 2018, from

https://internationalcriminalcourtnashie.weebly.com/aims-and-objectives.html.

International Criminal Court. Situation in Georgia. Retrieved March 17, 2018, from https://www.icccpi.int/georgia.

International Crisis Group. (2016, July 6). The Philippines: Renewing Prospects for Peace in Mindanao. Brussels.

International Military Tribunal (Nuremberg): Judgment of October 1, 1946. Retrieved November 3, 2018, from crimeofaggression.info/documents/6/1946_Nuremberg_Judgement.pdf.

International Military Tribunal for the Far East. (1946, January 19). Special proclamation by the Supreme Commander for the Allied Powers. Tokyo.

International Military Tribunal for the Far East. (1946, January 19). Special proclamation by the Supreme Commander tor the Allied Powers at Tokyo. Treaties and Other International Acts Series 1589. 
International Military Tribunal. (1945, August 8). Retrieved November 2, 2018, from http://www.un.org/en/genocideprevention/documents/atrocitycrimes/Doc.2_Charter\%20of\%20IMT\%201945.pdf.

International Military Tribunal. (1947). Trial of the Major War Criminals Before the International Military Tribunal. Nuremberg.

Introduction to the ECCC. (Undated). Retrieved May 20m 2019, from https://www.eccc.gov.kh/en/introductioneccc.

IRIN. (2003, October 6). Central African Republic: Reconciliation commission recommends government shakeup. Reliefweb.

Japan Institute of International Affairs. (2014, March). Japan's Territorial Issues and the Historical Understandings of the Concerned Countries: Case Studies on the Senkaku Islands, Takeshima and the Northern Territories. Tokyo.

Jeffery, R. (2017, January 7). The Solomon Islands Truth and Reconciliation Commission Report: Forgiving the Perpetrators, Forgetting the Victims? Transitional Justice in Practice. School of Government and International Relations \& Griffith University.

John. (2019, January 31). Burundi: Truth and Reconciliation Commission calls for multi-faceted support from international partners. Region Week.

Jovanovic, Spoma. (2012). Democracy, Dialogue and Community Action: Truth and Reconciliation in Greensboro. Fayetteville: University of Arkansas Press.

Jovanovic, Spoma. (2012). Democracy, Dialogue and Community Action: Truth and Reconciliation in Greensboro. Fayetteville: University of Arkansas Press.

Kaufman, Zachary D. (2010). The Nuremberg Tribunal v. The Tokyo Tribunal: Designs, Staffs, and Operations. 43 J. Marshall Law Review.

Kaufman, Zachary D. (2013). Transitional Justice for ToJo's Japan: The United States Role in the Establishment of the International Military Tribunal for the Far East and Other Transitional Justice Mechanism for Japan After World War II. Emory International Law Review. Volume 27.

Kelsall, T. (2005, May). Truth, Lies, Ritual: Preliminary Reflections on the Truth and Reconciliation Commission in Sierra Leone. Human Rights Quarterly, 27(2).

Kenya Transitional Justice Network. (2013, August). Summary: Truth, Justice and Reconciliation Commission Report. Nairobi: Kenya Human Rights Commission \& ICTJ.

Kenya. (2013). Report of the Truth, Justice and Reconciliation Commission. Nairobi: Truth, Justice and Reconciliation Commission.

Khan, I. (2008, August 30). Where are the disappeared? Dawn Media Group.

Killingsworth, M. (2019, March 13). Justice, Syria and the International Criminal Court. Australian Institute of International Affairs.

Kiswanson, N. (2018, May 28). What can Palestinians expect from the ICC? Al Jazeera. Doha.

Kostovicova, D. (2018, July 20). Sitting on the fence: How the London summit exposed the inertia in the EU's reconciliation policy for the Western Balkans. London School of Economics.

Kouassi, A. (2018, July 24). Altit Calls for 'Gbagbo's Immediate Release'. International Justice Monitor. Retrieved September 21, 2018, from https://www.ijmonitor.org/2018/07/altit-calls-for-gbagbos-immediate-release/.

Kramm, H. (2012). Bosnia's Failure in Creating a Truth Commission-How Institutions And Functions Encourage PostConflict Countries To Create a Truth Commission. Univertesit Twente.

Krasniqi, B. A. (2004, July). The Kosovo Early Warning Report. University of Prishtina and ResearchGate.

Kristianasen, W. (2006). "Truth \& Justice after a Brutal Civil War: Algeria: The Women Speak". Review of African Political Economy, 33 (108).

Ladisch, V. (Undated). Truth Commissions and Public History: Possibilities for Cyprus? International Center for Transitional Justice.

Lamb, K. (2016, April 13). Indonesia urged to hold truth and reconciliation process over massacres. The Guardian. Jakarta. 
Lassee, I. (2018). The Sri Lankan Office on Missing Persons: Truth and justice in tandem? International Review of the Red Cross, 99 (2).

Lawrence, G. (1947). "The Nuremberg Trial". International Affairs. Volume 23 (2): 151-159

Lela. (2019, March 26). Namibia advised to establish truth commission on genocide. Retrieved May 7, 2019, from https://www.lelamobile.com/content/79441/Namibia-advised-to-establish-truth-commission-on-genocide/.

Library of Congress. (2008, December 15). Bangladesh: Truth and Accountability Commission Declared Illegal. Global Legal Monitor.

Lopez, J. D. (2016, January 11). Genocide trial for Guatemala ex-dictator Rios Montt suspended. Reuters.

Luban, D. (1994). Legal Modernism: Law, Meaning, and Violence. Ann Arbor, MI: University of Michigan Press.

Lugmayr, A., Sutinen, E., Suhonen, J., Sedano, C. I., Hlavacs, H. \& Montero, C. S. (2017, December 11). Serious storytelling - a first definition and review. Multimed Tools Appl. Springer.

MacArthur, D. (1994). MacArthur in Japan: The Occupation Military Phase. Volume 1 Supplement. Washington.

Maclean, R. (2018, August 30). "I'm a revolutionary, not a criminal, Congo's 'Terminator' tells ICC". The Guardian. London.

Maclean, R. (2018, August 7). "Ivory Coast president pardons 800 people including ex-first lady". The Guardian. London.

Madoka, F. (2008). War crimes tribunals and transitional justice : the Tokyo Trial and the Nuremburg legacy. London; New York: Routledge.

Maletsky, C. (2005, November 28). Nujoma rejects calls for truth commission. Retrieved May 12, 2019, from https://www.namibian.com.na/index.php?id=17007\&page=archive-read.

Mandate for the Truth and Reconciliation Commission. Retrieved April 27, 2019, from http://www.residentialschoolsettlement.ca/SCHEDULE_N.pdf.

Margarnell, L. \& Wesley, J. (2008). Learning from Greensboro: Truth and Reconciliation in the United States. Philadelphia: University of Pennsylvania Press.

Mason, A. T. (1956). Harlan Fiske Stone: Pillar of the Law. New York: Viking.

McAdams, A. J. (2001, April). Judging the Past in Unified Germany. Cambridge University Press.

McKeown, T. (2014). The Nuremberg Trial: Procedural Due Process at the International Military Tribunal. Wellington:Victoria University.

Mejdini, F. \& Ristic, M. (2018, March 1). Digging for Truth in Communist Albania's Secret Files. Balkan Transitional Justice.

Mersky, M. (2005, March 7). Human Rights In Negotiating Peace Agreements: Guatemala. Belfast: The International Council on Human Rights Policy.

Michael, M. (2011, February 12). Egypt after Mubarak: finding truth in transition. OpenDemocracy.

Migyirka, E. N. (2008). Truth and Reconciliation Commissions: A Comparative Study of South Africa, Ghana and Sierra Leone. Burg: European University.

Milekic, S. (2018, July 10). Balkan Govts Dodge Signing Truth Commission Declaration. Balkan Transitional Justice.

Mollica, C. (2017, January 7). Youth Engagement in the Solomon Islands TRC Process. In Transitional Justice in Practice. School of Government and International Relations, Griffith University.

Moore, B. C. (2015, January). SWAPO in Exile and After: Dilemmas of Pragmatic Nationalism. South African Digital History Journal.

Moran, R. (2015, September 24). Truth and Reconciliation Commission. The Canadian Encyclopedia.

Morgan, A. (2009, May 28). ICJ denies Belgium request to force extradition of Chad ex-president Habre. In Jurist. JURIST Legal News and Research Services, Inc.

Murphy, S. D. (2012). The Crime of Aggression at the ICC. Public Law and Legal Theory Paper No. 2012-50. The George Washington University Law School.

Nain, Y. (2018, March 24). Transitional Justice in Sri Lanka: From Denial to Delay. The Diplomat.

National Inquiry into the Separation of Aboriginal and Torres Strait Islander Children from Their Families (1995 1997). Retrieved May 6, 2019, from https://www.findandconnect.gov.au/guide/vic/E000160. 
National Truth and Justice Commission. Retrieved April 17, 2017, from https://www.usip.org/publications/1995/04/truth-commission-haiti.

Naughton, E., \& Reátegui, F. (2016). Challenging the Conventional: Can Truth Commissions Strengthen Peace Processes? Ministry for Foreign Affairs of Finland, ICTJ \& Kofi Annan Foundation.

Nauman, Q. \& Shan, S. (2017, January 10). Rights Groups Ask Pakistan to Probe Disappearance of Activists. The Wall Street Journal.

Nazeer, T. (2018, March 8). "Sri Lanka: Muslims fear more attacks during Friday prayers". News/Asia.

Nazish, K. (2014, January 6). Balochistan's Missing Persons. The Diplomat.

Ndungú, C. G. (2014, May). Lessons to Be Learned: An Analysis of the Final Report of Kenya's Truth, Justice and Reconciliation Commission. New York: International Center for Transitional Justice.

Neil, B. \& Cryer, R. (2008). The Tokyo International Military Tribunal : a reappraisal. Oxfored University Press.

Nesiah, V. \& Keenan, A. (2004). Human Rights and Sacred Cows: Framing Violence, Disappearing Struggles. In N. Gordon (Ed.), From the Margins of Globalization: Critical Perspectives on Human Rights. Lanham Md: Lexington Books.

Ngarm, S.P. (2017). Cambodia Reconciliation: A Reflection on Justice and Reconciliation Issues and Challenges for the past 25 Years Post War - Peace and Reconciliation. Siem Reap: Centre for Peace and Conflict Studies.

NHRC issues notice to Government of Jammu and Kashmir. (Undated). Retrieved May 22, 2019, from http://nhrc.nic.in/press-release/nhrc-issues-notice-government-jammu-kashmir.

Nossiter, A. (2013, June 30). Senegal detains ex-President of Chad, accused in the deaths of opponents. In The New York Times. New York.

Noureddine, N. B. (2018, March 12). New Law for the Missing and Forcibly Disappeared in Lebanon Offers Hope to Victims' Families, Marks a Major Step Towards Justice. New York: International Center for Transitional Justice.

Nuremberg Trial Proceedings Vol. 1 Indictment: Appendix B. Retrieved August 2, 2019 from avalon.law.yale.edu/imt/countb.asp.

Nuremberg Trial Proceedings. (1945, November 21). Yale Law School.

Nuremberg Trials. (Undated). Retrieved May 28, 2019, from https://www.history.com/topics/world-warii/nuremberg-trials.

Nuremberg Trials. Retrieved November 11, 2018, from www.history.com/topics/world-war-ii/nuremberg-trials.

OAS. Retrieved September 15, 2018, from http://www.oas.org/fpdb/press/Letter-to-Prosecutor-of-ICC---May-312018.pdf.

Odartey-Wellington, F., \& Amin, A. (2006, April). Disseminating the national reconciliation commission report: A critical step in Ghana's democratic consolidation. African Journal of Political Science and International Relations, $10(4)$.

Ongiri, I. (2014, October 15). Uhuru Kenyatta's confidence rating up after ICC. Retrieved September 2, 2018, from https://www.nation.co.ke/news/politics/Uhuru-Kenyatta-ICC-Hague-Ipsos-Survey/-/1064/2487782//76qus1/-/index.html.

Oteng, E. (2019, February 8). Central African Republic to set up Truth, Justice and Reconciliation Commission. Africanews.com.

Outreach Programme on the Rwanda Genocide and the United Nations. (2014, March). The Justice and Reconciliation Process in Rwanda. New York.

Panama: Truth Commission Delivers its Final Report on Victims of the 1968-1988 Military Regime. (2002, May 2). NotiCen: Central American and Caribbean Affairs.

Paterson, P. (2016, January). Transitional Justice in Colombia: Amnesty, Accountability, and the Truth Commission. William J. Perry Center for Hemispheric Defense Studies. National Defense University.

Pathak, B. (2008, December 15). Modelling the Integration of the Maoist Army: DDR SSR? UK: Centre for Security Sector Management.

Pathak, B. (2013, February). Concepts and Major Initiatives of Human Security. Contemporary Sociological Global Review (CSGR). Volume 3. No. 3. 
Pathak, B. (2013, October 1). Origin and Development of Human Security. International Journal of Social and Behavioral Sciences. Vol. 1(9).

Pathak, B. (2015, August 29). Enforced Disappearance Commission: Truth, Justice and Reparation for Dignity. TRANSCEND Media Service.

Pathak, B. (2015, August 29). Enforced Disappearance Commission: Truth, Justice and Reparation for Dignity. TRANSCEND Media Service.

Pathak, B. (2015, May 18). Nepal' Enforced Disappearance Commission: Roles of International Community. TRANSCEND Media Service.

Pathak, B. (2016). World's Disappearance Commissions: An Inhumanious Quest for Truth. World Journal of Social Science Research. Vol. 3, No. 3.

Pathak, B. (2017). A Comparative Study of World's Truth Commissions: From Madness to Hope. World Journal of Social Science Research. Vol. 4, No. 3.

Pathak, B. (2018, July 30). World's Transitional Justice Ironically Ensures Freedom to the Perpetrators Further Limiting Justice to the Victims. TRANSCEND Media Service.

Pathak, B. (Forthcoming). Biswaka Sankramankalin Ayogharu: Satya, Nyaya ra Aviyojan Sandhai OJhelma (Truth Commissions in the World: Truth, Justice and Prosecution Always in Dark). Journal of Transitional Justice. Kathmandu: CIEDP.

Paulo, S. (2014, December 10). See the list of dead and missing of the military regime. Folha De S. Paulo.

Payne, R. (2011, February 17). A Truth Commission for Iraq. Duck of Minerva.

Pendas, D. (2005). The Frankfurt Auschwitz Trial, 1963-1965: Genocide, History, and the Limits of the Law. Cambridge: Cambridge University Press.

Perera, Y. \& Siriwardana, A. (2018, March 6). Outside group has created violence: PM. DailyMirror.

Peru's Painful Mirror. (Undated). Retrieved May 15, 2019, from

https://www.ictj.org/sites/default/files/subsites/perus-painful-mirror/.

Peterson, T. H. (2005). Final Acts: A Guide to Preserving the Records of Truth Commissions. Washington: Woodrow Wilson Center \& Johns Hopkins University Press.

Plessis, M. D. \& Ford, J. (2009, January). Transitional Justice: A Future Truth Commission for Zimbabwe. International and Comparative Law Quarterly, 58(01).

Potsdam. (1945, July 26). Proclamation Calling for the Surrender of Japan: Approved by the Heads of Governments of the United States, China, and the United Kingdom. Retrieved November 13, 2018, from http://www1.udel.edu/History-old/figal/hist371/assets/pdfs/potsdam.pdf.

Preliminary Examination: Afghanistan. Retrieved September 12, 2018, from https://www.icc-cpi.int/afghanistan. Preliminary Examination: Guinea. Retrieved September 1, 2018, from https://www.icc-cpi.int/guinea.

Preliminary Examination: Palestine. Retrieved September 1, 2018, from https://www.icc-cpi.int/palestine Preliminary Examination: Republic of Korea. Retrieved September 15, 2018, from https://www.icc-cpi.int/korea. Preliminary Examination: Ukraine. Retrieved August 12, 2018, from https://www.icc-cpi.int/ukraine.

President of the Republic of the Kosovo. (2019, April 19). The Preparatory Team, in public consultation with legal professionals. Pristina.

Press Release. (2014, June 23). Statement of the Prosecutor of the International Criminal Court, Fatou Bensouda, on the conclusion of the preliminary examination of the situation in the Republic of Korea. Hague.

Qamili, A. (2017, December 14). Kosovo President Established Truth and Reconciliation Commission Preparatory Team. Prishtina Insight.

Quinn, J. (2009, August 18). "Haiti's Failed Truth Commission: Lessons in Transitional Justice". Journal of Human Rights, 8(3).

Quinn, J. R. (2001). Dealing with a Legacy of Mass Atrocity: Truth Commissions in Uganda and Chile. Netherlands Quarterly on Human Rights 19 (4).

Rahman, I. A. (2016, August 25). Disappearances still a major issue. Dawn Media Group. 
Rappler. (2018, March 14). Statement of the President of the Republic of the Philippines on the Jurisdiction of the International Criminal Court. Manila.

RECOM. Retrieved May 18, 2019, from www.recom.link/about-recom/what-is-recom/.

Reconciliation. (2018, May 10). Truth-Telling Central to Reconciliation Process. Australia.

Redvers, L. (2015, February 6). Africa: Angola's fearful culture of silence. Mail and Guardian.

Republic of Rwanda. (Undated). National Unity and Reconciliation Commission. Retrieved May 28, 2019, from http://www.nurc.gov.rw/index.php?id=108.

Republic of Rwanda: National Unity and Reconciliation Commission. Retrieved May 13, 2019, from http://www.nurc.gov.rw/index.php?id=108.

Retrieved May 27, 2019, from www.bbc.com/bitesize/guides/zwmdfrd/revision/1.

Retrieved November 28, 2018, from http://libguides.law.uga.edu/c.php?g=177176\&p=1164581.

Retrieved October 7, 2018, from www.bbc.com/bitesize/guides/zwmdfrd/revision/1.

Retrieved September 24, 2018, from http://www.easterncongo.org/about-drc/history-of-the-conflict.

Reuters. (2018, March 16). Philippines informs U.N. of ICC withdrawal, court regrets move. Retrieved September 15, 2018, from https://www.reuters.com/article/us-philippines-duterte-icc-un/philippines-informs-u-n-of-iccwithdrawal-court-regrets-move-idUSKCN1GS0Y5.

RNZ. (2009, April 30). Solomon Commission claims broader support. Retrieved May 5, 2017, from http://www.radionz.co.nz/international/pacific-news/183421/solomons-commission-claims-broadsupport.

Robbins, J. (2017, December 31). The future of international justice. London: BBC.

Roberts, M. J. (2009, September). Conflict Analysis of the 2007 Post-election Violence in Kenya. New Dominion Philanthropy Metrics.

Rome Statute of the International Criminal Court. (2011). The Hague.

Rome Statute of the International Criminal Court. (July 17, 1998). Rome

Rothenberg, D. (Ed.). (2012). Memory of Silence: The Guatemalan Truth Commission. New York: Palgrave Macmillan.

Rudic, F. (2018, May 23). Balkans Truth Commission Plans to Start in 2022. Belgrade-Birn: Balkan Transitional Justice.

Rugiririza, E. (2018, November 1). Burundi: A Truth Commission as Political Diversion. Justiceinfo.net.

Rwanda, E. (2016, May 31). Togo officials learn from Rwanda's reconciliation process. Retrieved May 7, 2017, from http://rwandaeye.com/togo-officials-learn-from-rwandas-reconciliation-process/.

Ryan, H. B. (1998). The Fall of Che Guevara: A Story of Soldiers, Spies, and Diplomats. New York: Oxford University Press.

S/2005/60. (2005February 1). Report of the International Commission of Inquiry on Darfur to the SecretaryGeneral. New York.

Samad, A. (2016, April 29). The International Crimes Tribunal in Bangladesh and International Law. Criminal Law Forum, 27.

Sang-bun, H. (2004, April). A Hard journey to justice: first term report by the Presidential Truth Commission on Suspicious Deaths of the Republic of Korea (10.2000-10.2002). Korea.

Sang-Hun, C. (2007, December 3). Unearthing War's Horrors Years Later in South Korea. The New York Times. New York.

Sarkin, J. J. \& Davi, T. (2017). The Togolese Truth, Justice and Reconciliation Commission: Lessons for Transitional Justice Processes Elsewhere. Peace and Conflict Studies, 24(1).

Sarkin, J. J., \& Tetevi, D. (2017, April 4). The Togolese Truth, Justice and Reconciliation Commission: Lessons for Transitional Justice Processes Elsewhere. Peace and Conflict Studies, 24(1).

SC/8351. (2005, March 31). Security Council Refers Situation in Darfur, Sudan, to Prosecutor of International Criminal Court. New York. 
Schabas, W. (2006). The UN International Criminal Tribunals: The Former Yugoslavia, Rwanda, and Sierra Leone. Cambridge: Cambridge University Press.

Scharf, M. P. (1998, August). Results of the Rome Conference for an International Criminal Court. American Society of International Law. Volume 3. Issue 10.

Schwartz, D. (2016, June 2). “Truth and Reconciliation Commission: By the Numbers”. CBC News. Toronto.

Searcey, D. (2016, May 30). Hissène Habré, Ex-President of Chad, Convicted of War Crimes. The New York Times. New York

Sefton, S. (2019, February 12). Nicaragua's Truth Commission presents its Third Report. Axis of Logic.

Shapiro, B. (2001, May 2). Is it time for a Vietnam truth commission? Salon.

Shirer, W. L. (1960). The Rise and Fall of the Third Reich. A History of Nazi Germany. New York: Simon and Schuster.

Sieder, R. (2011). Contested sovereignties: Indigenous law, violence and state effects in postwar Guatemala.

Critique of Anthropology, 31(3).

Sieff, K. (2016, March 21). Africa: In historic ruling, international court cites rape in war crimes conviction of exCongo official. The Washington Post. Washington.

Sierra Leone and The Truth and Reconciliation Commission for Liberia. (Undated). New York: International Center for Transitional Justice. New York.

Singh, R. (2016, July 12). Kashmir: The World's Most Militarized Zone, Violence After Years of Comparative Calm. Forbes Media LLC.

Sirleaf, M. (Undated). Regional Approach to Transitional Justice?: Examining the Special Court for Sierra Leone and The Truth and Reconciliation Commission for Liberia. New York: International Center for Transitional Justice.

Situation in Uganda. Retrieved August 14, 2018, from https://www.icc-cpi.int/uganda.

Situations Under Investigation. Retrieved September 24, 2017 from https://www.icccpi.int/pages/situations.aspx.

Soendergaard, M. (2013, December 16). 45,000 missing persons in Colombia thought to be in mass graves. Colombia Reports.

Sofi, Z. (2019, January 17). Calendar of Disappeared People of Jammu and Kashmir. Newsclick.

Solsten, E. (1995). Germany: A Country Study. Washington: GPO for the Library of Congress.

South Sudan. (2018, May 14). Ministry of Justice and Constitutional Affairs Launches Consultations for the Creation of the Commission on Truth, Reconciliation and Healing in South Sudan. Juba: UNDP.

Ssenyonjo, M. (2017, June 13). State Withdrawal Notifications from the Rome Statute of the International Criminal Court: South Africa, Burundi and the Gambia. Criminal Law Forum.

Statement of apology to former students of Indian Residential Schools. (2008, June 11). Aboriginal Affairs and Northern Development Canada. Ottawa, Ontario: Government of Canada.

Stern, P. C. \& Daniel, D. (2010). International Conflict Resolution After the Cold War. Washington: National Academy Press.

Stewart, J. (2018, May 30-31). The Role of the ICC in the Transitional Justice Process in Colombia. The University Externado \& The University EAFIT.

Sverrisson, H. B. (2006, January). "Truth and Reconciliation Commission in Kosovo: A Window of Opportunity?" Peace, Conflict and Development, 8.

Tahhan, Z. (2018, May 22). Palestine submits ICC referral to open probe into 'Israel crimes'. Al Jazeera. Doha.

Tanaka, Y., McCormack, T., \& Simpson, G. (eds.). (2011). Beyond victor's justice?: the Tokyo War Crimes Trial revisited. International Humanitarian Law Series. Volume 30.

Taylor, Adam. (2014, December 10). Brazil's torture report brings a president to tears. The Washington Post. Teitel, Ruti G. (2000). Transitional Justice. Oxford University Press.

teleSUR. (2019, January 16). Mexico's Truth Commission To Begin Probe of Ayotzinapa Case. Retrieved May 15, 2019, from https://www.telesurenglish.net/news/Mexicos-Truth-Commission-To-Begin-Probe-of-AyotzinapaCase-20190116-0017.html. 
Testa, D. W. D., Lemoine, F, \& Strickland, J. (2003). Government leaders, military rulers, and political activists. Greenwood Publishing Group.

Thapa, S. (2017). A Dissertation for Master of Philosophy on the Peace Process and the TRC (Truth and Reconciliation Commission) in Nepal: A Comparative Study. Western Sydney University.

The Catholic Commission for Justice and Peace in Zimbabwe and The Legal Resource Foundation. (2001, October). Breaking the Silence: Building the True Peace. Harare.

The Center for Justice and Accountability. (Undated). Timor-Leste (East Timor): Crimes against Humanity Under Indonesian Occupation. San Francisco.

The Conversion. March 1, 2017. Dealing with Hate: Can America's Truth and Reconciliation Help? Retrieved March 7, 2018, from http://theconversation.com/dealing-with-hate-can-americas-truth-and-reconciliationcommissions-help-73170.

The Economist. (1946, October 5). The Editorial of the Nuremberg Judgment. London.

The Economist. (2005, October 6). Algeria: A flawed Charter. Cairo.

The Gazette of the Democratic Socialist Republic of Sri Lanka. (Undated). Retrieved May 21, 2017, from, https://www.usip.org/sites/default/files/file/resources/collections/commissions/SriLanka-Charter/S riLankaCharter_AP-6-N-214-97.pdf.

The Guardian. (2004, June 24). Special report: Truth, justice and reconciliation. Retrieved May 20, 2019, from https://www.theguardian.com/world/2014/jun/24/truth-justice-reconciliation-civil-war-conflict.

The Guardian. (2017, October 28). Burundi becomes first nation to leave international criminal court. London.

The Guardian. (2019, April 5). US revokes ICC prosecutor's visa over Afghanistan inquiry. London.

The Guardian. (2019, March 15). US to deny visas for ICC members investigating alleged war crimes. London.

The Hindu. March 6, 2018. Sri Lanka declares state of emergency following riots in Kandy. PTI Colombo.

The Missing in Colombia. Retrieved March 2, 2018, from https://www.usip.org/publications/2016/07/colombiaspeace-accord-missing.

The National Peace Council of Sri Lanka. (2018, June 7). Kandy DIRC Sets Up Citizens' Truth Commission. Colombo.

The New York Times. (2019, March 28). Tunisia Commission Releases Final Report on 50 Years of Dictatorship. New York.

The Nuremberg Trial and the Tokyo War Crimes Trials (1945-1948). Retrieved January 1, 2019, from history.state.gov/milestones/1945-1952/Nuremberg.

The Nuremberg Trial and the Tokyo War Crimes Trials (1945-1948). Retrieved December 8, 2018, from https://history.state.gov/milestones/1945-1952/nuremberg.

The Rwandan Genocide and Its Aftermath. Retrieved August 18, 2018, from http://www.unhcr.org/enmy/3ebf9bb60.pdf.

The Sunday Leader. (2018, February 26). Retrieved April 25, 2018, from http://www.thesundayleader.lk/2018/02/27/ampara-tense-following-attack-on-shop-and-mosque/.

Theidon, K. S., \& Laplante, L. J. (2007). Truth with Consequences: Justice and Reparations in Post-Truth Commission Peru. Human Rights Quarterly, 29.

Thompson, H.K. \& Henry Strutz. (1983). Doenitz at Nuremberg: A Re-Appraisal - War Crimes and the Military Professional. Amber Pub. Corp.

Time Magazine. (1946, October 29). War Crimes: Night without Dawn. New York.

Timothy, Maga. (2001). Judgment at Tokyo : the Japanese war crimes trials. University Press of Kentucky.

Tladi, Dire. (2015). The Duty on South Africa to Arrest and Surrender President Al-Bashir Under South Africa and International Law. Journal of International Criminal Justice. Volume 13.

Toledo, A. (2009, July 20). Healing the Past, Protecting the Future. American Quarterly.

Transitional Justice and Reconciliation Commission. (2016). Report of Transitional Justice and Reconciliation Commission. Philippines.

TRC Category 3: Amnesty. Retrieved May 1, 2017, from http://truth.wwl.wits.ac.za/cat_descr.php?cat=3 
TRIAL. (2016). Truth Commission of El Salvador. Geneva.

TRIAL. (2016, February 12). Truth Commission in Uganda. Geneva

Truth and Justice Commission. (November 2011). Land Reform: Legal and Administrative Aspects. Volume II. Truth and Justice Commission.

Truth and Justice Commission. Retrieved April 18, 2017, from https://www.usip.org/publications/1996/09/truthcommission-ecuador-96 Truth.

Truth and Justice: Unfinished Business in South Africa. (2003, February).

Amnesty International \& Human Rights Watch Briefing Paper.

Truth and Reconciliation Commission. (1998). A South African Report on Truth and Reconciliation Commission. Vol. 5.

Truth and Reconciliation Commission. (2005). Truth and Reconciliation: Activities of the Past Three Years. Seoul.

Truth and Reconciliation Commission. (2015). Honoring the Truth, Reconciling the Future. Canada.

Truth and Reconciliation Commission: Activities of the Past Three Years. (2009, March 20). Republic of Korea.

Truth Commission to Impede Impunity. Retrieved April 17, 2017, from

https://www.usip.org/publications/2007/05/truth-commission-ecuador-07/.

Tshuma, D. (2018, September 18). Reconciliation, Integration and Healing Efforts in Zimbabwe. African Center for the Constructive Resolution of Disputes.

UN Human Rights Council. (2018, September 17). Commission on Human Rights Urges South Sudan to make peace and justice a reality. Geneva.

UN Human Rights Council. (Undated). Commission on Human Rights in South Sudan. Geneva.

UN News. (2007, May 2). International Criminal Court issues warrants for first Darfur war crimes suspects.

Retrieved August 16, 2018, from https://news.un.org/en/story/2007/05/217552-international-criminal-courtissues-warrants-first-darfur-war-crimes-suspects.

UNDP. (2014, June 9). Tunisia launches Truth and Dignity Commission. New York.

UNHCR. (1994, November 16). Special Unit for Rwanda and Burundi, information meeting. Geneva.

United Nations International Criminal Tribunal for the former Yugoslavia. (2017, October 19). ICTY President Agius delivers final address to United Nations General Assembly. Hague.

United Nations Treaty Collections. Retrieved September 24, 2018, from https://treaties.un.org/Pages/ViewDetails.aspx?src=TREATY\&mtdsg_no=XVIII-10\&chapter=18\&clang=_en.

United Nations. (2002). Official Records of the United Nations Diplomatic Conference of Plenipotentiaries on the Establishment of an International Criminal Court: Rome, June 15 - July 17, 1998. Volume I. New York.

United Nations. (2018, October 15). UNOWAS welcomes the launch of the Truth, Reconciliation and Reparations Commission of The Gambia (TRRC). Retrieved May 11, 2019, from https://dppa.un.org/en/unowas-welcomeslaunch-of-truth-reconciliation-and-reparations-commission-of-gambia-trrc.

United Nations: Treaty Collection. (Updated). Retrieved May 29, 2019, from https://treaties.un.org/.

United Nations: Treaty Collection. Retrieved August 3, 2018, from https://treaties.un.org/.

United States Department of State. (1945). Foreign relations of the United States: Conferences at Malta and Yalta. Retrieved November 2, 2018, from Available in

http://images.library.wisc.edu/FRUS/EFacs/1945/reference/frus.frus1945.i0012.pdf.

United States Institute for Peace. (1999, February 1). Truth Commission: Guatemala. Washington.

United States Institute of Peace. (1974). Commission of Inquiry into the Disappearances of People in Uganda.

Washington.

United States Institute of Peace. (1974, June 30). Truth Commission: Uganda 74. Washington.

United States Institute of Peace. (1982, October 28). Truth Commission: Bolivia. Washington.

United States Institute of Peace. (1983, December 16). Truth Commission: Argentina. Washington.

United States Institute of Peace. (1983, September). Commission of Inquiry: Zimbabwe. Washington.

United States Institute of Peace. (1986, May 16). Truth Commission: Uganda 86. Washington. 
United States Institute of Peace. (1990, December 29). Truth Commission: Chad. Washington.

United States Institute of Peace. (1990, December 29). Truth Commission: Chad. Washington.

United States Institute of Peace. (1990, January 1). Commission of Inquiry: Nepal 90. Washington.

United States Institute of Peace. (1992, July 1). Truth Commission: El Salvador. Washington.

United States Institute of Peace. (1992, May). Truth Commission: Germany. Washington.

United States Institute of Peace. (1993, January 1). Special Prosecutors' Office: Ethiopia. Washington.

United States Institute of Peace. (1995, April 1). Truth Commission: Haiti. Washington.

United States Institute of Peace. (1995, December 1). Truth Commission: South Africa. Washington.

United States Institute of Peace. (1995, December 1). Truth Commission: South Africa. Washington.

United States Institute of Peace. (1995, January 1). Commission of Inquiry: Sri Lanka. Washington.

United States Institute of Peace. (1995, January 1). Commission of Inquiry: Sri Lanka.

United States Institute of Peace. (1995, July 1). Truth Commission: Germany 95. Washington.

United States Institute of Peace. (1999, June 12). Truth Commissions: Nigeria. Washington.

United States Institute of Peace. (1999, March 1). Truth Commission: Rwandan 99. Washington.

United States Institute of Peace. (2000, August 1). Truth Commission: Uruguay. Washington.

United States Institute of Peace. (2000, October 1). Truth Commission: South Korea 2000. Washington.

United States Institute of Peace. (2001, January 1). Panama Truth Commission. Washington.

United States Institute of Peace. (2001, July 13). Truth Commission: Peru 01. Washington.

United States Institute of Peace. (2001, November 1). Truth Commission: Sierra Leone. Washington.

United States Institute of Peace. (2002, February 1). Truth Commission: Serbia and Montenegro. Washington.

United States Institute of Peace. (2002, November 1). Truth Commissions: Sierra Leone. Washington.

United States Institute of Peace. (2002, October 4). Report of the Chilean National Commission of Truth and Reconciliation. Washington.

United States Institute of Peace. (2002, October 4). Report of the Chilean National Commission of Truth and Reconciliation. Washington.

United States Institute of Peace. (2003, July 1). Truth Commission: Democratic Republic of Congo. Washington. United States Institute of Peace. (2003, July 1). Truth Commission: Democratic Republic of Congo. Washington. United States Institute of Peace. (2003, September 21). Commission of Inquiry: Algeria. Washington.

United States Institute of Peace. (2004, December 1). Truth Commission: Morocco. Washington.

United States Institute of Peace. (2004, January 13). International Commission of Inquiry for Burundi: Final Report. Washington.

United States Institute of Peace. (2004, June 1). Truth Commission: Paraguay. Washington.

United States Institute of Peace. (2006, February 20). Truth Commission: Liberia. Washington.

United States Institute of Peace. (2007, February). Commission for Reception, Truth and Reconciliation in EastTimor. Washington.

United States Institute of Peace. (2007, May 3). Truth Commission: Ecuador 07. Washington.

United States Institute of Peace. (2009, April 29). Truth Commission: Solomon Islands. Washington.

United States Institute of Peace. (2012, February 9). Mauritius: Truth and Justice Commission. Washington.

United States Institute of Peace. (2012, February 9). Mauritius: Truth and Justice Commission. Washington.

United States Institute of Peace. (2012, February 9). Truth Commission: Honduras 2010. Washington.

United States Institute of Peace. (2012, February 9). Truth Commissions: Mauritius. Washington.

United States Institute of Peace. (2017, August 2). Reconciliation and Transitional Justice in Nepal: A Slow Path. Washington. 
Uruguay. (2002). Annual Report of the EAAF. Retrieved May 18, 2017, from http://eaaf.typepad.com/pdf/2002/15Uruguay.pdf.

US Department of State. (2007). 2007 Country Report on Human Rights Practices of Paraguay. Washington. US Department of State. (2007). 2007 Country Report on Human Rights Practices of Paraguay. Washington.

Valji, N. (2006, September). Ghana's National Reconciliation Commission: A Comparative Assessment. New York: International Center for Transitional Justice.

Valussi, R. (October 25, 2015). Ivory Coast: Social cohesion at the ballot box. Aljazeera.

Vivanco, J.M. (2018, May 14). Nicaragua's 'Truth Commission' a Farce. Human Rights Watch.

VOA. (2011, April 10). Ivory Coast's Gbagbo Captured at Presidential Compound. USA.

VOA. (2016, December 13). Kenya Signals Possible ICC Withdrawal. Africa.

Voice of Eritrean Woman. (2016, October 30). Eritrea: Deconstructing the Commission of Inquiry's Report. Retrieved March 9, 2018, from https://stesfamariam.com/2016/10/30/eritrea-deconstructing-the-commissionof-inquirys-report/.

Wakabi, W. (2016, October 6). Bemba lays out grounds for Appeal against ICC convention. International Justice Monitor. New York: Open Society Foundations.

Walker, J. (2009, February 11). The Indian Residential Schools and Truth and Reconciliation Commission. Parliamentary Information and Research Service.

Walker, C. (2005, June 2). Truth and Reconciliation: Aboriginal people conflicted as commission wraps up after 6 years. CBC News. Toronto.

Wanyeki, M. L. (2012, August). The International Criminal Court's cases in Kenya: origin and impact. Paper No. 237. Institute of Security Studies.

Wielenga, C. (2015, February). Peacebuilding in Burundi: Is a Truth and Reconciliation Commission the Answers? University of Pretoria.

Wierda, M. \& Triolo, A. (2012, May 31). Luc Reydams; Jan Wouters; Cedric Ryngaert (eds.). International Prosecutors. Oxford University.

Wijk, J. V. (2012). Amnesty for War Crimes in Angola: Principled for a Day? International Criminal Law Review 12. Martinus Nijhoff Publishers.

Wilson, S., Cribb, R., Trefalt, B., \& Aszkielowicz, D. (2017). Japanese War Criminals: the Politics of Justice after the Second World War. New York: Columbia University Press.

Wintour, P. (2017, November 4). "ICC's investigation of Libya war crimes in duck even before male rape cases". The Guardians. London.

Workers Viewpoint Organization. (1979, November 1). Smash the Klan with correct understanding and armed selfdefense. Greensboro: The University of North Carolina.

Wright, Quincy. (1948, April). Legal Positivism and the Nuremberg Judgment. American Journal of International Law, 42 (2).

Wyzanski, C. E. (1946, April). Nuremberg: A Fair Trial? A Dangerous Precedent. Retrieved November 10, 2018, from www.theatlantic.com/magazine/archive/1946/04/ nuremberg-a-fair-trial-a-dangerousprecedent/306492/.

Yakinthou, C. (2016, August 28). Truth commissions as reconciliation roulette. CyprusMail.

Yale Law School. (2008). Lillian Goldman Law Library. New Haven.

Yusuf, H. O. (2007, August 10). Travails of Truth: Achieving Justice for Victims of Impunity in Nigeria. The International Journal of Transitional Justice, 1(2).

Zupan, N. (2006). Facing the Past and Transitional Justice in Countries of the Former Yugoslavia. BosniaHerzegovina: Peacebuilding and Civil Society. 


\section{Notes}

i The term "genocide" was first coined by Raphael Lemkin during World War II. He used this term to describe the serious crimes committed against the Jews by the Nazis (Lemkin, April 1946). The word genocide derives from the ancient Greek genos race, class, tribe and people (Conversi, January 20, 2006). The U.N. General Assembly adopted the Convention on the Prevention and Punishment of the Crime of Genocide (Genocide Convention) and Genocide Convention marked the first time as an international legal instrument (Resolution 260 (III) A, December 9, 2009 and Absar, March 26, 2014).

ii Crimes against humanity, revived from Nuremberg Trial, connects to both international and non-international armed conflict (Breyer, November 1996). Crimes against humanity are committed against fellow nationals as well as foreigners (Luban, 2004), but often fall upon the tribunal jurisdiction (Cherif Bassiouni, 2011). The crimes against humanity include: murder; enforced disappearances, extermination; enslavement, deportation, imprisonment, torture, rape, the crime of apartheid and among other inhumane acts (Article 7 of the Rome Statute of the ICC, July 17, 1998).

iii In the case of War Crimes, it is an act that constitutes a violation of the laws of war that ensures individual criminal responsibility (Cassese, 2013). The ICC illustrates that War Crimes includes intentionally killing civilians or prisoners or humanitarian workers and surrendered personnel, using civilians as shields and child soldiers, taking hostages, bombing on civilian populations, destroying civilian property and among others in international and non-international armed conflicts (Article 8 of the Rome Statute of the ICC, July 17, 1998). The War Crimes further defines on Hague Conventions, Geneva Conventions, Nuremberg Trials, and International Military Tribunal for the Far East and so on.

iv The word 'aggression' was endorsed by the UN General Assembly immediately after World War II (Cassese, 2013: 111). The UN War Commission stated that there was no consensus on Crimes of Aggression under international law (Brownlie, 1963:159). The Crimes of Aggression have been adopted by the UN Assembly of States Parties through a Review Conference held in the Rome Statute in Kampala from May 31 to June 11, 2010 (Ambos, 2011:463-509). The act of aggression includes the invasion, military operation or occupation, blockade and annexation by the use of force violating the UN Charter (Murphy, 2012). Aggression on Article 8.b Rome Statute of the ICC includes planning, preparation, initiation and execution using armed forced by the concerned State against the sovereignty, territorial integrity and political independence of another State.

v The ICC comprises four organs: the Presidency, the Chambers (Pre-Trial, Trial and Appeals Divisions), the Office of the Prosecutor and the Registry. Each of the organs has a specific role and mandate. The Presidency consists of three judges: the President and two Vice-Presidents, which were to be elected by an absolute majority of the 18 judges of the Court for a maximum of two, three-year terms. The Presidency is mainly responsible for the administration of the Court. In the Chambers, the Pre-Trial, Trial and Appeals Division composed of seven, six and five judges respectively. The Office of the Prosecutor is an independent organ of the Court which has a mandate to receive and analyze information of serious crimes within the jurisdiction of the Court. The Prosecutor determines whether there is enough reason to initiate an investigation into the crimes and to bring the perpetrators of these crimes before the Court. The Registry helps to conduct fair, impartial and public trials in the Court (Goel, December 12, 2013). 